Key Words:

Actinides

Ion Exchange

Salt Disposition

Plutonium

Retention:

Permanent

\title{
PHASE I TECHNICAL REPORT FOR THE ENGINEERING OF MONOSODIUM TITANATE
}

\author{
Charles A. Nash \\ David T. Hobbs \\ Kofi Adu-Wusu \\ Edgar C. Buck, Pacific Northwest National Laboratory
}

JULY 30, 2004

Westinghouse Savannah River Company

Savannah River Site

Aiken, SC 29808

Prepared for the U.S. Department of Energy Under

Contract Number DE-AC09-96SR18500

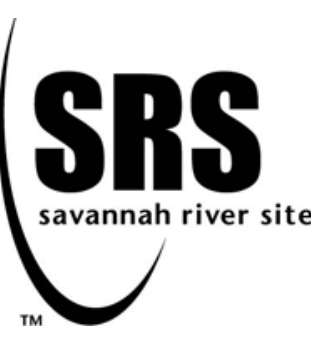


This document was prepared in conjunction with work accomplished under Contract No. DE-AC09-96SR18500 with the U. S. Department of Energy.

\section{DISCLAIMER}

This report was prepared as an account of work sponsored by an agency of the United States Government. Neither the United States Government nor any agency thereof, nor any of their employees, makes any warranty, express or implied, or assumes any legal liability or responsibility for the accuracy, completeness, or usefulness of any information, apparatus, product or process disclosed, or represents that its use would not infringe privately owned rights. Reference herein to any specific commercial product, process or service by trade name, trademark, manufacturer, or otherwise does not necessarily constitute or imply its endorsement, recommendation, or favoring by the United States Government or any agency thereof. The views and opinions of authors expressed herein do not necessarily state or reflect those of the United States Government or any agency thereof.

This report has been reproduced directly from the best available copy.

Available for sale to the public, in paper, from: U.S. Department of Commerce, National Technical Information Service, 5285 Port Royal Road, Springfield, VA 22161, phone: (800) 553-6847, fax: (703) 605-6900

email: orders@ntis.fedworld.gov

online ordering: http://www.ntis.gov/help/index.asp

Available electronically at http://www.osti.gov/bridge

Available for a processing fee to U.S. Department of Energy and its contractors, in paper, from: U.S. Department of Energy, Office of Scientific and Technical Information, P.O. Box 62, Oak Ridge, TN 37831-0062,

phone: (865)576-8401,

fax: (865)576-5728

email: $\underline{\text { reports@ adonis.osti.gov }}$ 
This page was intentionally left blank 
Key Words:

Actinides

Ion Exchange

Salt Disposition

Plutonium

Retention:

Permanent

\title{
PHASE I TECHNICAL REPORT FOR THE ENGINEERING OF MONOSODIUM TITANATE
}

\author{
Charles A. Nash \\ David T. Hobbs \\ Kofi Adu-Wusu \\ Edgar C. Buck, Pacific Northwest National Laboratory
}

JULY 30, 2004

Westinghouse Savannah River Company

Savannah River Site

Aiken, SC 29808

Prepared for the U.S. Department of Energy Under

Contract Number DE-AC09-96SR18500

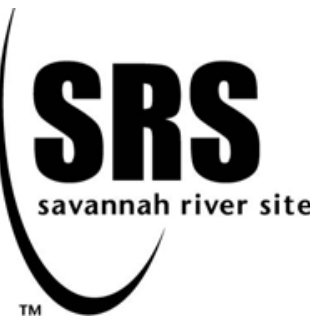




\section{TABLE OF CONTENTS}

LIST OF FIGURES ....................................................................................................

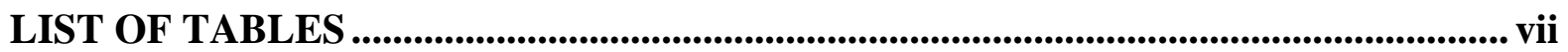

LIST OF ACRONYMS AND ABBREVIATIONS ............................................................... viii

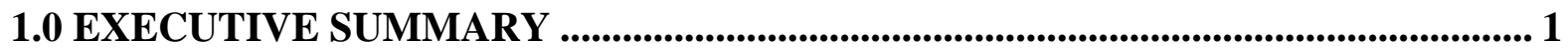

2.0 CD-ROM ENCLOSURES..................................................................................... 1

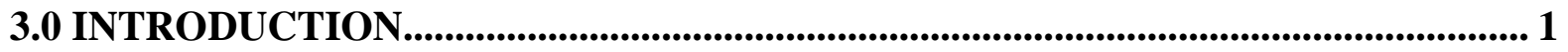

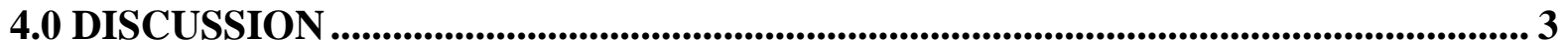

4.1 Description of Monosodium Titanate ................................................................................ 3

4.2 Survey of Methods to Engineer an Inorganic Powder ....................................................... 4

4.3 Sorbents Tested and Physical Properties .......................................................................... 6

4.3.1 Commercially Available Baseline Materials............................................................... 6

4.3.2 UOP, Inc. Samples..................................................................................................... 7

4.3.3 ORNL Samples ........................................................................................................... 7

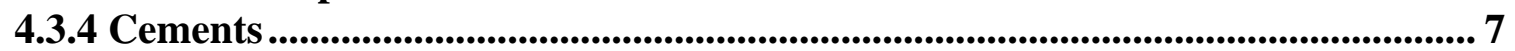

4.3.5 Clemson Sample ....................................................................................... 10

4.3.6 Internal Hydrolysis Samples .................................................................................... 11

4.4 Physical and Chemical Characterization ......................................................................... 12

4.5 Chemical Stability Testing................................................................................................. 15

4.6 Salt Solutions for Batch Contact Testing .................................................................... 17

4.7 Batch Contact Procedures .................................................................................................. 18

4.8 Results of Batch Contacts ...................................................................................................... 19

4.8.1 Spiked Simulant Testing with Engineered MST Samples..................................... 19

4.8.2 Actual Tank Composite Tests with Three Engineered Materials....................... 24

4.8.3 Spiked Simulant Testing with Selected Materials at a Phase Ratio of $25,000 \mathrm{~mL} / \mathrm{g}$................................................................................................................. 26

4.8.4 Uncertainties in Measurement and Solution Stability ............................................ 29

4.8.5 Comparison of Spiked Simulant and Actual Tank Composite Data................. 30

4.9 Flowsheet and DWPF Impacts of the Use of Engineered MST.................................. 32

4.10 Cost Evaluation of Engineered MST Materials.............................................................. 32

4.11 Quality Assurance.................................................................................................................... 33

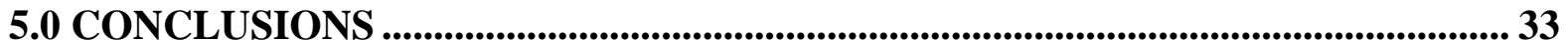

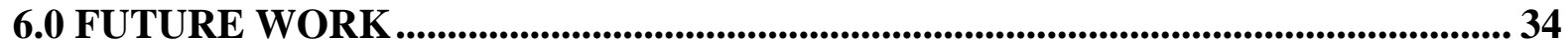

7.0 ACKNOWLEDGEMENTS .............................................................................................. 34

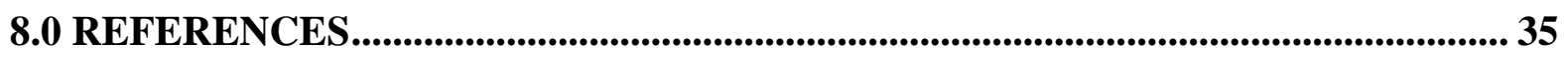

APPENDIX A. SPECIFICATION SHEETS

APPENDIX B. SUMMARY DESCRIPTION OF THE MANUFACTURE OF OAK RIDGE BEADS 


\section{LIST OF FIGURES}

Figure 1. UOP Process for Engineering CST with Zirconium Hydroxide .............................. 5

Figure 2. Aluminosilicate Cement from Ludox and Sodium Aluminate.................................. 8

Figure 3. X-ray Diffraction Data for SrTreat ${ }^{\circledR}$ Adsorbent .................................................. 14

Figure 4. X-ray Diffraction Data for ORNL 50 wt \% MST Adsorbent Beads ....................... 14

Figure 5. Crystals from Soaking Hydroxyapatite Cement in Simulant .................................. 15

Figure 6. Crystals from Soaking Mg/Al/PO4 Cement in Simulant ....................................... 16

Figure 7. Soluble Plutonium versus Time for the First Batch Contacts ................................ 21

Figure 8. Plutonium Decontamination Factors for the First Batch Contacts......................... 21

Figure 9. Plutonium Distribution Coefficients for the First Batch Contacts ......................... 22

Figure 10. Strontium-85 Decontamination Factors from Spiked Simulant Batch Contacts.. 23

Figure 11. Time Dependence of Strontium Decontamination ............................................... 23

Figure 12. Neptunium-237 Decontamination Factors from Spiked Simulant

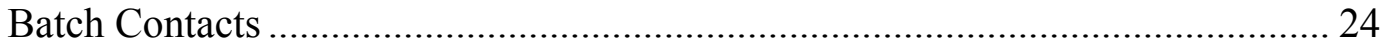

Figure 13. Plutonium Distribution Coefficients from Actual Waste Batch Contacts............ 25

Figure 14. Strontium Decontamination from Actual Waste Batch Contacts......................... 26

Figure 15. Plutonium Distribution Coefficients at Two Phase Ratios.................................... 28

Figure 16. Strontium Decontaminations in the Second Set of Spiked Simulant

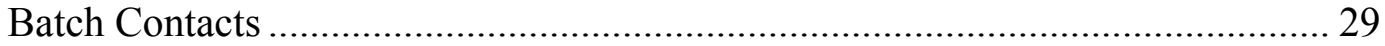

Figure 17. Comparison of Simulant vs. Actual Tank Composite Pu Adsorption for

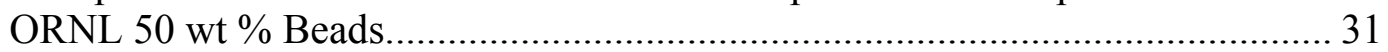

Figure 18. Comparison of Simulant vs. Actual Tank Composite Sr Adsorption for ORNL $50 \mathrm{wt} \%$ Beads.

Figure 19. Comparison of Simulant vs. Actual Tank Composite Pu Adsorption for SrTreat $^{\mathbb{B}}$ 


\section{LIST OF TABLES}

Table 1. Mean Volume-Weighted Particle Size and Dispersity ..................................... 13

Table 2. Weight Percent MST and Dry Bed Density of Engineered Materials .................... 13

Table 3. Square-Weighted Mean Particle Chord Length, Microns, Over Time ................... 17

Table 4. Composition of the Salt Simulant ......................................................................... 17

Table 5. Actinide Levels in the Salt Simulant, microgram/L .......................................... 17

Table 6. Key Radioactive Element Levels in the Tank Composite Salt Solution ................ 18

Table 7. Sample Masses Containing 0.1 grams MST Equivalent for Batch Contacts.......... 20

Table 8. Second Set of Spiked Simulant Batch Contacts .............................................. 27

Table 9. Activities and Total Error in Control Solutions.................................................... 30 


\section{LIST OF ACRONYMS AND ABBREVIATIONS}

$\begin{array}{ll}\text { ADS } & \text { Analytical Development Section } \\ \text { ARP } & \text { Actinide Removal Process } \\ \text { CETL } & \text { Clemson Environmental Technologies Laboratory } \\ \text { CST } & \text { Crystalline Silicotitanate } \\ \text { DF } & \text { Decontamination Factor } \\ \text { DOE } & \text { Department of Energy } \\ \text { DOE-HQ } & \text { Department of Energy - Head Quarters } \\ \text { DWPF } & \text { Defense Waste Processing Facility } \\ \text { ESP } & \text { Efficient Separations and Processing Crosscutting Program } \\ \text { FBO } & \text { Federal Business Opportunities } \\ \text { high p } & \text { Phase ratio 25,000 mL/g } \\ \text { HLW } & \text { high level waste } \\ \text { Int. Hydr. } & \text { Internal hydrolysis } \\ \text { ITP } & \text { In-Tank Precipitation } \\ \text { K } & \text { Distribution Coefficient } \\ \text { MST } & \text { Monosodium Titanate } \\ \text { ND } & \text { Not detected } \\ \text { ORNL } & \text { Oak Ridge National Laboratory } \\ \text { PNNL } & \text { Pacific Northwest National Laboratory } \\ \text { SRNL } & \text { Savannah River National Laboratory } \\ \text { SWPF } & \text { Salt Waste Processing Facility } \\ \text { TPT } & \text { Tetraisopropyl Titanate } \\ \text { XRD } & \text { X-ray Diffraction } \\ & \end{array}$




\subsection{EXECUTIVE SUMMARY}

Monosodium titanate (MST) is an inorganic adsorbent that effectively removes strontium, plutonium, uranium, and other trace elements from alkaline salt supernate. Current plans use the MST in batch contact processes to treat Savannah River Site (SRS) waste solutions that require

${ }^{90} \mathrm{Sr}$ and actinide removal to meet low level disposal criteria. More effective use of MST may be realized if the MST could be engineered into a form suitable for a continuous treatment process such as an adsorption column. The main benefits of column operation are (1) enhanced loading due to equilibration with feed adsorbate levels versus product levels, and (2) a small footprint relative to that of a batch contact tank.

The current baseline MST material features particles of nominally 0.5-35 micron in size, which are much too fine for use in an adsorption column. An extensive review of the literature and consultation with technical experts identified candidate methods to produce engineered forms of MST. From this list a review team selected five candidate methods for further study. Laboratory syntheses at Savannah River National Laboratory (SRNL) and offsite produced representative samples for characterization and performance testing. Testing identified two suitable methods. The two methods include internal gelation, which is patented technology of Oak Ridge National Laboratory, and internal hydrolysis, a method in which the MST is produced within a porous substrate. A commercial sodium titanate, SrTreat ${ }^{\circledR}$, produced by Fortum Engineering (Finland), demonstrated good performance as well although plutonium removal kinetics appeared much slower than observed for the other engineered MST materials.

\subsection{CD-ROM ENCLOSURES}

A CD-ROM was created with the file copy of this report. It contains experimental data files and photographs.

\subsection{INTRODUCTION}

The Savannah River Site (SRS) selected the inorganic adsorbent monosodium titanate (MST) as the means of removing strontium and key actinides from salt waste solutions. ${ }^{1}$ MST was used in In-Tank Precipitation. It has been included in other processing plans such as those for the Salt Waste Processing Facility (SWPF) and Actinide Removal Process (ARP). The micron-sized particles of MST are created by a sol-gel process. Its use has up to now been in batch contacts in processing tanks followed by filtration of the decontaminated salt solution.

The Savannah River National Laboratory (SRNL) received funding from the Department of Energy - Head Quarters (DOE-HQ), Office of Cleanup Technologies (EM-21), via the National Energy Technologies Laboratory (NETL) to engineer MST into particles suitable for column use. The proposal describing the work was submitted in February 2003. ${ }^{2}$ Use of such material in adsorption columns could substitute for MST batch processing in-tank, at ARP or at SWPF. Engineering MST into nominally 500 micron particles would allow steady column processing of salt solution and provide certain benefits. Column use of an adsorbent allows maximum loading because the adsorbent is equilibrated with feed levels of adsorbate. Process columns have small footprints relative to batch contact tanks and also operate continuously rather than in batch mode. 
Process filtration would see lower demand because it would be upstream of the column. It would remove sludge fines without the need for MST removal.

A Savannah River National Laboratory (SRNL)-sponsored workshop in mid-2001 recommended methods for the engineering of MST. ${ }^{3}$ Methods and background were later reviewed by materials scientists and other experts in a Creativity "SWAT" Team at SRNL prior to beginning this work. ${ }^{4}$ That review was meant to provide the broadest possible view of practical engineering methods. The results were refined in a downselection evaluation involving glass chemistry and materials science experts within the SRNL Waste Treatment Technology department. ${ }^{5}$ The evaluation selected the UOP method used for engineering crystalline silicotitanate (CST), use of cement binders, spray drying, formation of MST within porous particles, and internal gelation per Oak Ridge National Laboratory (ORNL) technology for further pursuit. Downselection criteria included likelihood of commercialization, downstream impacts, perceived cost, likelihood of good performance, and intellectual property issues. More specific criteria for the experimental program included freedom from organic content, $30 \times 60$ mesh particle size, effective porosity, toleration of high sodium and alkaline solutions, and minimal fines generation.

This work includes a study on the Defense Waste Processing Facility (DWPF) impacts and also a risk assessment. These are documented separately. ${ }^{6,7}$ The DWPF impacts assessment found that use of engineered MST had minimal impact on number of glass canisters produced because the glass chemistry was not titanium-limited. Risks of highest consequence for the program involve questions about rheological interactions of engineered materials with sludge, ability to scale up and procure new material that meets specifications, and impacts on glass composition. Approaches would include testing and some risk transfer to other programs.

Deployment is likely in-tank, on a skid, or in an existing process cell. Deployment in an existing tank or facility allows maximum use of radiological shielding. Since MST is considered nonelutable its deployment is simplified over a column needing elution with, perhaps, acid feed. ${ }^{8}$ If a skid is used, shielding requirements are lower than would be needed for a more-difficult cesium removal task (only if cesium is removed first).

The objective of this work was to further the development of engineered MST for the following Department of Energy (DOE) nuclear complex needs:

- Need for cost effective technology to remove strontium and actinides from salt wastes for the sake of accelerated low curie salt cleanup,

- Rapid, compact, and efficient processing that can be deployed in or near an existing facility or tank, and

- Disposal of adsorbed, concentrated strontium and actinides either in the DWPF (vitrification) or direct disposal of the sorbent in a HLW repository. 


\subsection{DISCUSSION}

\subsection{Description of Monosodium Titanate}

Monosodium titanate was first prepared by Lynch, et al. ${ }^{9}$ The preparation method consisted of mixing a methanol solution of $\mathrm{NaOH}$ with a methanol solution of titanium isopropoxide. The MST was then precipitated by addition of water. The chemical formula is $\mathrm{NaTi}_{2} \mathrm{O}_{5} \mathrm{H}$ and the solid is totally amorphous. This compound was found to exhibit high selectivities for strontium and several actinides. ${ }^{10}$ Subsequently, much work has been reported on strontium uptake by similar materials prepared by treatment of hydrated $\mathrm{TiO}_{2}$ with $\mathrm{NaOH} .{ }^{11,12,13}$

SRS evaluated and selected MST for strontium removal in conjunction with cesium removal by precipitation as the tetraphenylborate salt for the in-tank precipitation (ITP) process. MST exhibited high strontium removal capacity at acceptable removal rates along with the added benefit of plutonium removal. Testing also indicated that the quantity of MST required for ${ }^{90} \mathrm{Sr}$ and actinide removal did not adversely impact high-level waste glass chemistry and physical properties. SRNL developed a modified synthesis of MST that produced a material tailored for the ITP deployment in a large reactor tank (1.3 million gallon) and batch operation. ${ }^{14}$ The synthesis steps are in an appendix of the cited report.

Testing at SRNL indicated that the MST successfully removed sufficient ${ }^{90} \mathrm{Sr}$ and alpha-emitting radionuclides to meet the requirements for disposing of the decontaminated waste solution in a low-level cement-based wasteform. ${ }^{15}$ Actinide removal characteristics of the MST became an increasingly important issue in the early 1990s as waste characterization data revealed an increasing need to remove alpha-emitting radionuclides from HLW supernates. ${ }^{16}$ Also of concern was the accumulation of fissile radionuclides onto the MST from a nuclear criticality safety basis. Accumulation of fissile isotopes onto the MST was found to be below levels that would pose a nuclear criticality safety concern. ${ }^{17}$ Thus, the use of MST proved acceptable for the ITP process.

Specifications for commercial procurement of MST were developed. ${ }^{18}$ The MST specifications require a minimum strontium decontamination factor, an acceptable particle size range and an allowable solids concentration among other items. Pelletizing, gelation, or cementation methods of engineering MST in this work used an existing inventory of MST originally procured for use in the In-Tank Precipitation operation. This quantity of MST was produced by Optima Chemical Company, Inc., (Douglas, GA) in 1995 and identified as batch \#95-QAB-451. WSRC returned this material to Optima in 2000 for rework and it is now identified as Batch \#00-QAB-417.

SRNL characterized this batch because of its extensive use in studies requiring MST. ${ }^{19,20}$

The sorption characteristics of MST decrease upon heating. Dosch quantified the loss of capacity versus temperature from room temperature up to $500{ }^{\circ} \mathrm{C} .{ }^{21}$ Engineering methods that require elevated temperatures may thus result in the loss of sorption characteristics versus the baseline MST material. 


\subsection{Survey of Methods to Engineer an Inorganic Powder}

A primary goal in the technical proposal for this work was to perform a practical survey of existing engineering methods to benefit from their history of experience. SRNL held a workshop on engineering methods in 2001, providing a list of candidate methods. ${ }^{3}$ This section reviews past efforts and indicates how the information was used in this test program.

Desired characteristics of the engineered materials were first defined, drawing on the 2001 workshop and engineering knowledge of column operations. ${ }^{3}$ The past effort to engineer CST was also considered. The desired pellet product (1) shall contain only trace organic compounds that pose no downstream processing concerns, (2) shall contain MST still retaining good adsorption characteristics, (3) have a preferred particle size distribution for the engineered particles between 250 and 600 micron ( $30 \times 60$ mesh) with a mean size near 380 microns, (4) shall be sufficiently porous so that adsorption is still practical, (5) shall tolerate up to 7 molar sodium salts with up to 3 molar free hydroxide, and (6) shall generate few fines, allowing practical sorption column operation. MST is a single-use material, thus elution and strong acid stability is not an issue.

There has been extensive work over the past few decades to use zirconium hydroxide and phosphate as adsorbents themselves as well as binders for incorporated inorganic adsorbents. ${ }^{22,23}$ A notable recent use of such a binder for nuclear waste treatment has been the engineering of CST by UOP, Inc. Figure 1 shows a summary-level and non-proprietary diagram of the process. IE 910 refers to the powdered form of CST that is an input stream. IE 911 is the beaded product of nominally $30 \times 60$ mesh ( 250 to 600 micron diameter). The means of forming and setting the zirconium hydroxide binder is proprietary to UOP, Inc.

UOP, Inc. agreed to perform this process using MST provided by SRNL. In addition SRNL also issued a Federal Business Opportunity (FBO) call soliciting participation by other commercial entities. ${ }^{24}$ There was one inquiry but no corporate offers to participate. 


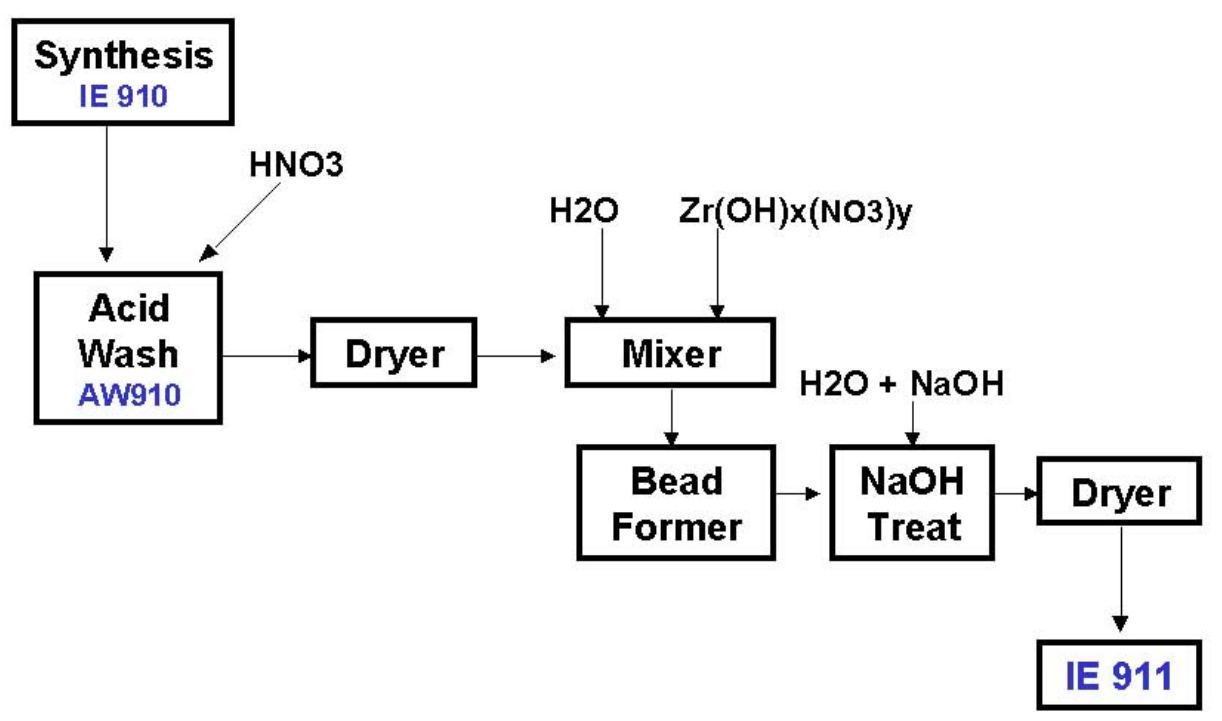

Figure 1. UOP Process for Engineering CST with Zirconium Hydroxide

Internal gelation is an engineering process that has had extensive development in Czechoslovakia as well as at the ORNL. ${ }^{26,27,28,29,30}$ Much of the work was directed at reactor fuel production using inorganic materials such as uranium oxide, but adsorbents were also studied. During the 1990s a research and development program entitled Development and Testing of Spheroidal Inorganic Sorbents was sponsored by the Efficient Separations and Processing Crosscutting Program (ESP) at ORNL. The program successfully engineered sodium titanate powder, a material relatively similar to MST. Internal gelation is capable of binding solids using a variety of metal hydroxides including those of zirconium, titanium, and iron.

A desire to use low-temperature setting inorganic binders led to the investigation of cements. The various types that were considered are reviewed below. Benefits of cements would include relative ease of manufacture of a MST-bearing solid, low temperature processing, use of reagents that are often inexpensive, and often a solid containing phosphate which might help adsorb actinides.

Magnesium phosphate and magnesium-aluminum phosphate cements have received much study because they are quick-setting and set at low temperatures. ${ }^{31}$ Recipes are generally simple and include magnesium oxide in acid-base reactions with acid phosphate salts such as those of potassium, ammonium, aluminum, or phosphoric acid. Their ease of use has led to much work on toxic and radioactive waste stabilization at Argonne National Laboratory. ${ }^{32,33}$ One of Argonne's primary products, Ceramicrete ${ }^{\mathrm{TM}}$, was further studied for the stabilization of CST inorganic sorbent at the SRS. ${ }^{34}$ Ceramicrete $^{\mathrm{TM}}$ powder was available from that work. In addition the current work examined a magnesium-aluminum phosphate cement. ${ }^{35}$

Calcium phosphate cements were considered because extensive work has been done on them for medical uses. ${ }^{36,37}$ In addition the major phase of calcium phosphate in the cements after curing is 
almost always hydroxyapatite. ${ }^{38}$ Hydroxyapatite, a component of bone char, is known to be the active adsorbent when bone char is used to adsorb actinides from nuclear waste. ${ }^{39}$ One drawback of calcium phosphate cement formulations is the complexity of the chemistries and crystallinities of the various reagent calcium phosphate salts. ${ }^{40,41}$

Aluminum silicate cements were examined because they are easy to make and may form chemically stable solids similar to sodium aluminosilicate and other stable foulants in SRS evaporator pots. ${ }^{42,43}$ One body of technology for synthesizing these is the "geopolymer" chemistry developed by Davidovits. ${ }^{44}$ The aluminosilicate material can be filled with other solids and has also been marketed to bind nuclear and toxic sludges under the name Geopolytech ${ }^{\circledR}{ }^{45}$ Information from these expired patents was used to form cement binders in the current work.

Internal hydrolysis is another method for engineering MST. It was first performed by R. Dosch, inventor of MST, using porous glass beads and 8-12 mesh molecular sieves. ${ }^{46}$ The method was duplicated in the current work with more suitable substrates. The method involves first obtaining a porous material of desired particle shape, mesh size, and chemical stability. The dry porous material is then soaked in an anhydrous alcohol solution containing tetraisopropyl titanium and sodium methoxide to fill the pores completely. The particles are then immersed in a water-containing alcohol solution to effect precipitation of MST in the pores by the hydrolysis reaction. Bray used this method to fill the pores of zeolite with sodium titanate. ${ }^{47}$ However, differences with current work include different chemicals used in the hydrolysis and the fact that Bray only achieved $5 \mathrm{wt} \%$ loading of active sorbent in the zeolite matrix. ${ }^{48}$ Despite the lower loading than seen in current work Bray reported plutonium breakthroughs $\left(\mathrm{C} / \mathrm{C}_{0}>0.5\right)$ only after passing in excess of 2600 bed volumes of alkaline feed through $2 \mathrm{~mL}$ beds in columns.

Several engineering methods considered failures in the past were not pursued further here. These methods included the use of isostatic pressing and also calcium aluminate binding. ${ }^{49}$ Investigators performing the past work on these methods observed disintegration of the pellets into fine solids when soaked in salt solutions of interest. Loading of an anion exchange resin with titanate ion was also not pursued here because the titanate so produced would not be MST but more properly sodium titanate.

\subsection{Sorbents Tested and Physical Properties}

\subsubsection{Commercially Available Baseline Materials}

MST from batch 00-QAB-417 was used as a baseline for batch testing and was also provided to all investigators for the production of engineered MST samples that initiate with MST solids. MST from the same drum was thus used at SRNL; UOP, Inc.; ORNL; and Clemson.

A sample of SrTreat ${ }^{\circledR}$ was obtained from Fortum Engineering (Fortum, Finland). The sample was stated to have the commercially available particle size range of 300 to 850 microns. The particle shape is non-spherical and granular. See the specification sheet in Appendix A. 


\subsubsection{UOP, Inc. Samples}

UOP, Inc. provided two samples of pelletized MST to SRNL. One sample was spherical and within the requested $30 \times 60$ mesh size range. The other sample was of elongated pellets in what UOP called their "trilobe" shape. UOP, Inc. indicated that each sample contained $80 \mathrm{wt} \% \mathrm{MST}$. Titanium analyses at SRNL confirmed the MST content within $+/-2 \mathrm{wt} \%$.

\subsubsection{ORNL Samples}

ORNL provided two samples of engineered MST produced by the internal gelation method. These spherical materials were reported to contain 32 and $50 \mathrm{wt} \% \mathrm{MST}$. Actual MST content could not be measured by titanium content because the binder used to prepare these samples also contained titanium. We thus used the reported values for the MST content to establish quantities to use in the performance testing. Appendix B provides a description of the laboratory procedure used to prepare these materials.

\subsubsection{Cements}

SRNL researchers prepared a number of cement-bound MST samples. These include aluminosilicate, magnesium phosphate, magnesium aluminum phosphate and calcium phosphate cements. Best engineering judgment and scoping tests were used to select samples from each effort. Researchers checked scoping samples qualitatively for friability and rejected many attempts because they crumbled easily between the fingers. There were many attempts to make cement samples and these are shown in the laboratory notebook. ${ }^{50}$ Following is a summary of the findings from the synthesis and characterization of these materials.

\section{Aluminum Silicate Cements}

Researchers first produced aluminosilicate materials without MST using various sources of silicate and aluminum. Aluminum trihydroxide was not found to be very reactive. While it would form a solid when mixed with potassium hydroxide and colloidal silica (DuPont Ludox ${ }^{\circledR}$ with $34 \mathrm{wt} \%$ silica in water), some of the aluminum trihydroxide settled within the sample before it completely set overnight.

Much better was the solid resulting from the intimate mixture of sodium aluminate with Ludox ${ }^{\circledR}$. The $40 \mathrm{wt} \%$ silica form of Ludox ${ }^{\circledR}$ was used to reduce the amount of water in the sample. Sodium aluminate was mixed in at a Si:Al molar ratio of 2:1. This produced a viscous and almost homogeneous slimy-looking liquid. It was kept warm in an oven overnight at 50 to 60 ${ }^{\circ} \mathrm{C}$. The product was brittle, creamy white, and homogeneous except for small voids. It contained very small glassy bubbles that were visible under a microscope. Figure 2 is a photograph of the material. One piece was stored at room temperature over a weekend while another piece was baked at 50 to $60{ }^{\circ} \mathrm{C}$ concurrently. XRD found that the piece stored at room temperature was amorphous while some Zeolite A had grown into the piece kept warm in the oven for the additional 3 days.

The MST-filled sample for this work was made by mixing $2.743 \mathrm{~g}$ of sodium aluminate with $6.098 \mathrm{~g}$ of air-dried MST cake. MST cake had been prepared by filtration, water washing, and 
air-drying at room temperature for at least a day. After these solids were thoroughly ground and mixed with a mortar and pestle, the researcher put the mixture in a beaker with $10.287 \mathrm{~g}$ of Ludox ${ }^{\circledR}$ having $40 \mathrm{wt} \%$ silica. The researcher mixed the thick paste and allowed it to set at room temperature overnight. The product set up well and the researcher judged the recipe viable. Researchers scaled up the recipe by mixing $8.3096 \mathrm{~g}$ of sodium aluminate with 22.7387 $\mathrm{g}$ of air-dried MST cake. After these solids were thoroughly ground and mixed with a mortar and pestle, researchers put the mixture in a beaker with $31.1752 \mathrm{~g}$ of Ludox ${ }^{\circledR}$ having $40 \mathrm{wt} \%$ silica. The material set up well overnight at room temperature and was saved for later grinding and sieving.

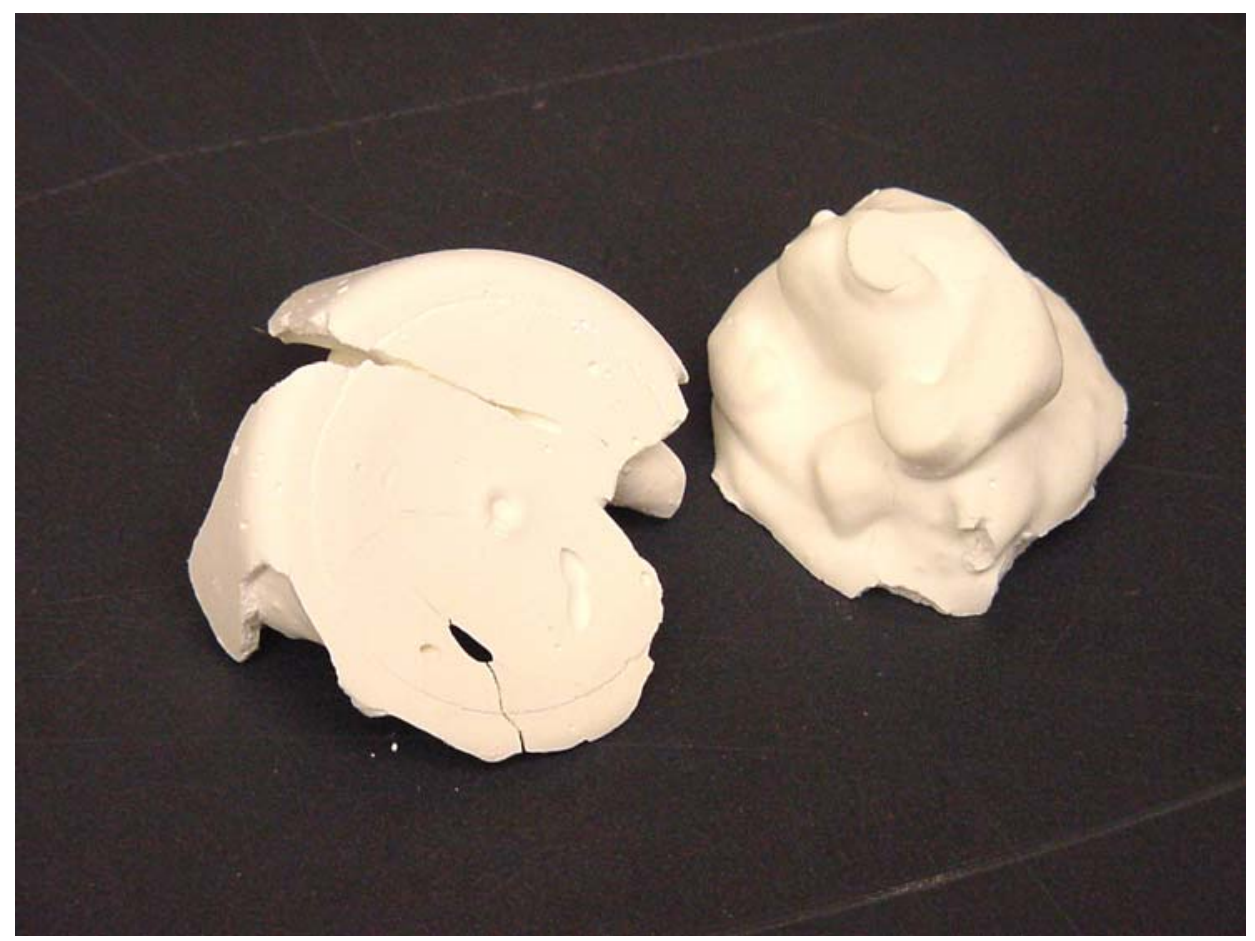

Figure 2. Aluminosilicate Cement from Ludox and Sodium Aluminate

Magnesium Phosphate and Magnesium Aluminum Phosphate Cements

Researchers found it easy to make quick-setting magnesium phosphate and magnesium aluminum phosphate cements. Researchers used reagent-grade magnesium oxide that they calcined at $1050{ }^{\circ} \mathrm{C}$ just weeks prior to the cement-making efforts. The magnesium oxide was ground with potassium dihydrogen phosphate $\left(\mathrm{KH}_{2} \mathrm{PO}_{4}\right)$ in a 2:6.8 mass ratio as found in reference 31. A damp cake of $50 \mathrm{wt} \% \mathrm{MST}$ was added to the mixture of cement-formers. Water was kept to a minimum because it is also formed by the setting of this acid-base cement. Researchers observed that apparent viscosity of this and other phosphate cements dropped noticeably at the time that a phosphate-containing component, either salt or acid based, was added to the mixture. Beakers of this cement were allowed to set at room temperature overnight. 
Researchers made magnesium aluminum phosphate cements by mixing magnesium oxide $(\mathrm{MgO})$ powder with a syrup of aluminum orthophosphate (AOP). They first prepared the AOP syrup by mixing aluminum trihydroxide powder with $85 \mathrm{wt} \%$ phosphoric acid. Such a mixture reacts with some heating and the solids dissolved into the acid to make clear syrup. The Al:P molar ratio for the mixture was 1:3, so the syrup probably contains dihydrogen phosphate ion. MST was introduced into these recipes as moist de-ionized water-washed cake mixed with the $\mathrm{MgO}$. Such a mixture was extremely viscous but it thinned substantially when the AOP was added.

Ceramicrete $^{\mathrm{TM}}$ cement powder as-produced from Argonne National Laboratory was available and was tested. Researchers made samples according to directions. ${ }^{32}$ Researchers made samples of the unfilled cement by adding water to the powder and mixing. The cement paste took about 10 minutes to self-heat. Additionally researchers made MST-filled samples by mixing Ceramicrete $^{\mathrm{TM}}$ powder with damp MST cake in a 1:1 weight mixture (dry Ceramicrete ${ }^{\mathrm{TM}}$ : MST on a dry basis). Damp cake contained $2 / 3$ mass of water so researchers added less than $1.3 \mathrm{~mL}$ additional water to $20.35 \mathrm{~g}$ Ceramicrete ${ }^{\mathrm{TM}}$ and $61.1 \mathrm{~g}$ of damp cake at the start of mixing.

The work discovered that successful mixing was very dependent on mixing technique. Researchers exploited the slurry-thinning ability of phosphate in the following way. They added minimal water, less than $2 \mathrm{~mL}$, to a corner of the mixing beaker. They introduced Ceramicrete ${ }^{\mathrm{TM}}$ powder and MST cake in small amounts to the area. The water dissolved a little Ceramicrete ${ }^{\mathrm{TM}}$ including its phosphate salt component. This created a region of fluid slurry that could then be used to take in additional solids and cake without losing its fluidity. Researchers used a mixing rod only in this fluid region and were able to make the fluid region grow until all contents of the beaker were well-mixed and fluid. Researchers completed mixing, covered the beaker with a watchglass to maintain humidity, and put the beaker in a $37^{\circ} \mathrm{C}$ oven overnight to set the product.

Simple soak testing quickly eliminated Ceramicrete ${ }^{\mathrm{TM}}$ products from consideration. Researchers discovered that alkaline 5.6 M sodium solution caused swelling and disintegration of pieces of the cement within a day or so. This occurred despite the fact that the initial cured cement was rock-hard.

\section{Calcium Phosphate Cements}

The researchers spent much time attempting to make samples from various calcium phosphate cements. One motivating factor was that both bone char and cured calcium phosphate cements have in common the component hydroxyapatite. Bone char had been the focus of some past efforts to find an inexpensive actinide adsorbent solid.

The main difficulty with calcium phosphate cements is the complexity of calcium phosphate crystal forms and morphology. The cements are also sensitive to the environmental conditions during curing. Researchers investigated cement recipes including mixtures of calcined calcium oxide, calcium dihydrogen phosphate, calcium hydroxide, disodium hydrogen phosphate solution, and various calcium:phosphate ratios. ${ }^{51,52}$ In addition a researcher contacted medical cement companies and obtained samples from these commercial sources.

Stryker ${ }^{\circledR}$ Corporation (Allendale, NJ) provided about 50 grams of BoneSource ${ }^{\circledR}$ cement powder. Bone surgeons use this medical product to promote bone growth in areas of breakage. The powder makes an easy-to-use white putty when $0.32 \mathrm{~mL}$ of de-ionized water is added per gram 
of powder. The researcher found that mixing was easy and that the powder wet and handled well. He discovered though that the cement formed cracks and made a physically weak product when allowed to set at room temperature overnight. The vendor then pointed out that this material needs conditions exactly as found in the human body for good setting: $100 \%$ humidity and a temperature of $37{ }^{\circ} \mathrm{C}$. These conditions were indeed found to improve the apparent strength of the product.

HiMed $^{\circledR}$ Corporation (Old Bethpage, NY) also provided samples. HiMed ${ }^{\circledR}$ sample \#1 consisted of $60 \mathrm{wt} \%$ tetracalcium phosphate, $30 \mathrm{wt} \%$ dicalcium phosphate dehydrate, and $10 \mathrm{wt} \%$ tricalcium phosphate. HiMed ${ }^{\circledR}$ sample \#2 was $100 \%$ tricalcium phosphate. Both products require $1 \mathrm{M} \mathrm{NaOH}$ solution for setting. A minimum weight ratio of $2: 1$ of HiMed $^{\circledR}$ products to alkaline solution is the recommended weight ratio. HiMed ${ }^{\circledR}$ personnel recommended we test even higher weight ratios and cement setting conditions of $100 \%$ relative humidity and $37{ }^{\circ} \mathrm{C}$.

$\mathrm{HiMed}^{\circledR}$ representatives noted that some forms of calcium phosphate are relatively expensive and hard to obtain because of various difficult manufacturing steps required to control crystal form and particle size. One step involves a rapid quench of red-hot powder to room temperature by proprietary means. HiMed ${ }^{\circledR}$ personnel were not aware of process scales above the kilogrambatch sizes that they manufacture.

After many trials with the Stryker ${ }^{\circledR}$ and HiMed ${ }^{\circledR}$ calcium phosphate cements, we selected the Stryker Bonesource ${ }^{\circledR}$ material loaded with $25 \mathrm{wt} \%$ MST for further testing. The selection was made because the Bonesource ${ }^{\circledR}$ material was least friable.

\subsubsection{Clemson Sample}

SRNL was in the process of completing operations with a hot oil column at the Clemson Environmental Technologies Laboratory (CETL). Researchers took the opportunity to engineer MST before dismantling the rig. This sol-gel process used colloidal silica in most cases but colloidal zirconium hydroxide was used for engineering $\mathrm{MST}^{53}$

We provided air-dried MST cake to CETL. They created a well-mixed slurry of it with $20 \mathrm{wt} \%$ zirconium (VI) oxide colloidal solution. They adjusted the ratio of MST solids to solution so that the slurry was thick but still pumpable in his hot oil rig. They avoided clogging the system by sending the slurry through a 100 mesh screen before use. They reported that there were larger chunks of solid that made the screening necessary.

The rig used a peristaltic pump to deliver slurry through a needle into the top of the 27-foot tall silicone oil column. Oil at $70{ }^{\circ} \mathrm{C}$ set and partly dehydrated the slurry. The set droplets (beads) were collected on a screen at the bottom of the column. They were washed with hexanes to remove the oil. CETL reported that the slurry was easy to handle and set up well as desired in the process. The pear shape of the beads showed that the slurry was quick-setting out of the needle. We found that the beads were $7.8 \mathrm{wt} \% \mathrm{Ti}$ and $14.2 \mathrm{wt} \% \mathrm{Zr}$. The titanium level translates to an MST content of $16.1 \mathrm{wt} \%$. 


\subsubsection{Internal Hydrolysis Samples}

The internal hydrolysis method of engineering MST requires a porous chemically stable solid substrate. The materials used in the past per Section 4.2 were known or quickly shown to not meet the current criteria for engineered materials. Specifically, organic ion exchange resins contain carbon which is unacceptable here. Five inorganic substrates were screened for use using a simple alkali salt soak test. Porous or "thirsty" glass was quickly eliminated from consideration because it showed visible degradation in one day of soaking in the salt solution.

Standard granular grade $30 \times 60$ mesh Florisil $^{\circledR}$, Supelco catalog number 288691-250G was purchased from Supelco (Bellefonte, PA). Florisil ${ }^{\circledR}$ is a porous magnesium silicate used in analytical chromatography. In initial caustic soak testing its particles were found to solidify into a cake and it was quickly judged to be unacceptable for use.

Porous alumina samples were provided by Saint-Gobain Norpro ${ }^{\circledR}$ (Akron, OH) and also by Poroce ${ }^{\circledR}$ Corporation (Little Rock, AR). The Saint-Gobain material had sample number 2002650354, type SA52124. It was a sample of 1300 micron diameter spheres. Smaller spheres were not available because the catalyst industry served by this company does not have interest in a smaller product. The Poroce ${ }^{\circledR}$ material was their Dynocel $600^{\circledR} 30$ x 60 mesh granules. Both of these materials showed no degradation when soaked in alkali salt solutions.

K28 high temperature insulating firebrick was obtained from Morgan-Thermal Ceramics. The specification sheet for this material (new trade name JM-28) is in Appendix A. The firebrick was pulverized and sieved to obtain 30 x 60 mesh granules. Slightly larger pieces showed no visible degradation in simple caustic salt soaking.

The hydrolysis of tetraisopropyl titanium (TPT) in highly alkaline alcohol solution forms MST solids. This requires an anhydrous solution "A" of $30 \mathrm{~mL}$ TPT, $11.6 \mathrm{~mL}$ of $4.4 \mathrm{M}$ sodium methoxide in methanol, and $120 \mathrm{~mL}$ isopropyl alcohol. Solution "B", of $15.4 \mathrm{wt} \%$ water and isopropyl alcohol, forms MST solids by a hydrolysis reaction with solution "A". MST is engineered by first soaking a dried porous substrate in solution " $\mathrm{A}$ " using several cycles of vacuum to make sure that there is no air in the pores. The researcher then drains the excess solution " $\mathrm{A}$ " and adds excess solution "B" to form MST within the pores of the solid. The solids are then heated to near boiling for an hour followed by an overnight soak. Excess MST is washed away the next day and the product is air dried at room temperature. The laboratory notebook provides the details for this work. ${ }^{50}$

The first effort used the St. Gobain spheres and the Porocel ${ }^{\circledR}$ Dynocel granules. The researcher initially measured MST content of the products by a dry-basis mass balance on substrate before and after hydrolysis. The St. Gobain material was ruled out at this step because it only picked up $2 \mathrm{wt} \%$ MST. The Porocel ${ }^{\circledR}$ material gained $10 \mathrm{wt} \% \mathrm{MST}$. That material was analyzed for titanium content and the result was used as the quantitative measurement for batch contact work.

An effort was made to increase the loading of MST in new Porocel ${ }^{\circledR}$ substrate, and the K28 (JM28) firebrick granules were also processed. Solution "A" contained only $10 \mathrm{~mL}$ of isopropyl alcohol rather than $120 \mathrm{~mL}$ so that all reacting chemicals were more concentrated. The water 
content of solution "B" was set to $50 \mathrm{wt} \%$ in this case. Titanium content indicated that the Porocel substrate was $12.6 \mathrm{wt} \% \mathrm{MST}$ and the K28 firebrick was $11.8 \mathrm{wt} \% \mathrm{MST}$. The more highly loaded Porocel ${ }^{\circledR}$ material was used in the second set of spiked simulant batch contacts and is named the "new" internal hydrolysis sample.

\subsection{Physical and Chemical Characterization}

All samples were characterized by bed density, x-ray diffraction (XRD), and optical photography. The Pacific Northwest National Laboratory (PNNL) analyzed the ORNL and internal hydrolysis samples by scanning electron microscopic and transmission electron microscopic techniques. ${ }^{54}$

PNNL provided clear images of the fibrous structure in the ORNL internal gelation beads. The fibrous structure appears similar to that found for MST in other work. ${ }^{55}$ This indicated that the process did not remove this characteristic of the added MST and that the hydrous titanium oxide binder might also have this form. The internal hydrolysis material, in contrast, appeared to be a mostly homogeneous mixture of titanium and aluminum oxides. That material was rough on the microscale but did not show a fibrous structure.

The work detected some urea nitrogen and also some organic carbon in the ORNL beads that was apparently left behind in the processing. Efforts to quantify the levels of these chemicals in the sample were not successful but the work did show that further pursuit of this issue is warranted.

Sample particle size distributions were measured in water using a Microtrac ${ }^{\circledR}$ S3000 laser scattering analyzer. The results are in Table 1. The UOP trilobe and the Clemson samples were not measured because their particles exceeded the 700 micron upper limit of the instrument. The mean value is the mean diameter, microns, of the volume distribution. This is a weighted value of the "average particle size", or center of gravity of the distribution. All samples were within the desired 250 to 595 micron range. However, the SrTreat ${ }^{\circledR}$ and the Bonesource ${ }^{\circledR}$ (hydroxyapatite) cement containing MST were not readable by the technique. The analyst was not able to explain the problems. He did note that these samples seemed to have more visible fines and turbidity than the other samples. Overall he saw normal-sized particles in the samples but the Microtrac ${ }^{\circledR}$ instrument was not reading them correctly.

The standard deviation, microns, describes the width of the measured particle size distribution. It is not an indication of the statistical error about the mean of multiple measurements. It is onehalf of the $84^{\text {th }}$ minus $16^{\text {th }}$ percentile. 
Table 1. Mean Volume-Weighted Particle Size and Dispersity

\begin{tabular}{|l|c|c|}
\hline \multicolumn{1}{|c|}{ Engineered Sample } & $\begin{array}{c}\text { Mean Value } \\
\text { (microns) }\end{array}$ & $\begin{array}{c}\text { Standard } \\
\text { Deviation } \\
\text { (microns) }\end{array}$ \\
\hline UOP Beads & 523 & 112 \\
\hline ORNL 50 wt \% MST Beads & 573 & 105 \\
\hline SrTreat ${ }^{\mathbb{B}}$ & $5^{*}$ & $4^{*}$ \\
\hline ORNL 32 wt \% MST Beads & 520 & 81 \\
\hline Mg-AOP Cement & 407 & 165 \\
\hline Al-Si Batch 1 Cement & 450 & 166 \\
\hline Al-Si Batch 2 Cement & 457 & 156 \\
\hline Hydroxyapatite Cement & $*$ & $*$ \\
\hline Internal Hydrolysis Batch & 530 & 145 \\
\hline
\end{tabular}

* Turbidity prevented accurate measurement

Bed density and weight percent MST are important properties for column calculations since the amount of active adsorbent per bed volume is needed. We determined bed density by pouring the dry materials into 10-mL graduated cylinders and gently tapping until we observed no further change in settling. Knowledge of bed mass and indicated volume provided the densities in Table 2. All work was done in duplicate so that deviation from the mean could be reported.

Weight percent MST was determined by dissolution of a known quantity of each sample and measuring the titanium content by inductively coupled plasma emission spectroscopy (ICP-ES). The sodium peroxide fusion method using nickel crucibles was successfully used to dissolve the samples. Weight percent MST is the ratio of molecular weights, $(199.8 /(2 * 47.9)$ or 2.086$)$ times the weight percent titanium in each sample that is not titanium oxide-bound.

Table 2. Weight Percent MST and Dry Bed Density of Engineered Materials

\begin{tabular}{|l|r|r|r|}
\hline Sample & $\begin{array}{c}\text { Weight } \\
\text { Percent MST }\end{array}$ & $\begin{array}{c}\text { Dry Bed Density } \\
\text { Average g/mL }\end{array}$ & $\begin{array}{c}\text { +/- Error, } \\
\text { percent }\end{array}$ \\
\hline SrTreat $^{(}$ & 86. & 0.863 & 1.74 \\
\hline UOP Beads & 78.6 & 1.125 & 1.18 \\
\hline UOP Trilobe & 80.5 & Not measured & \\
\hline ORNL 50 wt \% Beads & 50. & 0.991 & 0.97 \\
\hline ORNL 32 wt \% Beads & 32. & 1.053 & 0.00 \\
\hline Mg-AOP & 39.6 & 0.747 & 0.01 \\
\hline Al-Si Batch 1 & 35.7 & 0.736 & 0.00 \\
\hline Al-Si Batch 2 & 38.4 & 0.813 & 0.83 \\
\hline Hydroxyapatite & 25 & 0.840 & 0.84 \\
\hline Internal Hydrolysis & 9.9 & 0.642 & 1.25 \\
\hline New Int Hydrolysis & 12.6 & 0.669 & 0.33 \\
\hline K-28 Firebrick & 11.8 & 0.746 & 0.02 \\
\hline
\end{tabular}


The Analytical Development Section (ADS) of SRNL performed XRD of all samples of interest to identify presence of crystalline phases. The materials are generally amorphous as evidenced by broad peaks in the XRD spectra. In some cases, we observed small amounts of anatase $\left(\mathrm{TiO}_{2}\right)$. Examples of this are shown below for SrTreat ${ }^{\circledR}$ and for the ORNL $50 \mathrm{wt} \% \mathrm{MST}$ bead sample. The vertical lines are the tentative assignment of anatase that was suggested by the XRD data processing software. The processing software was unable to identify the pattern of small peaks in Figure 3 (SrTreat $\left.{ }^{\circledR}\right)$ and indicated this with question marks.

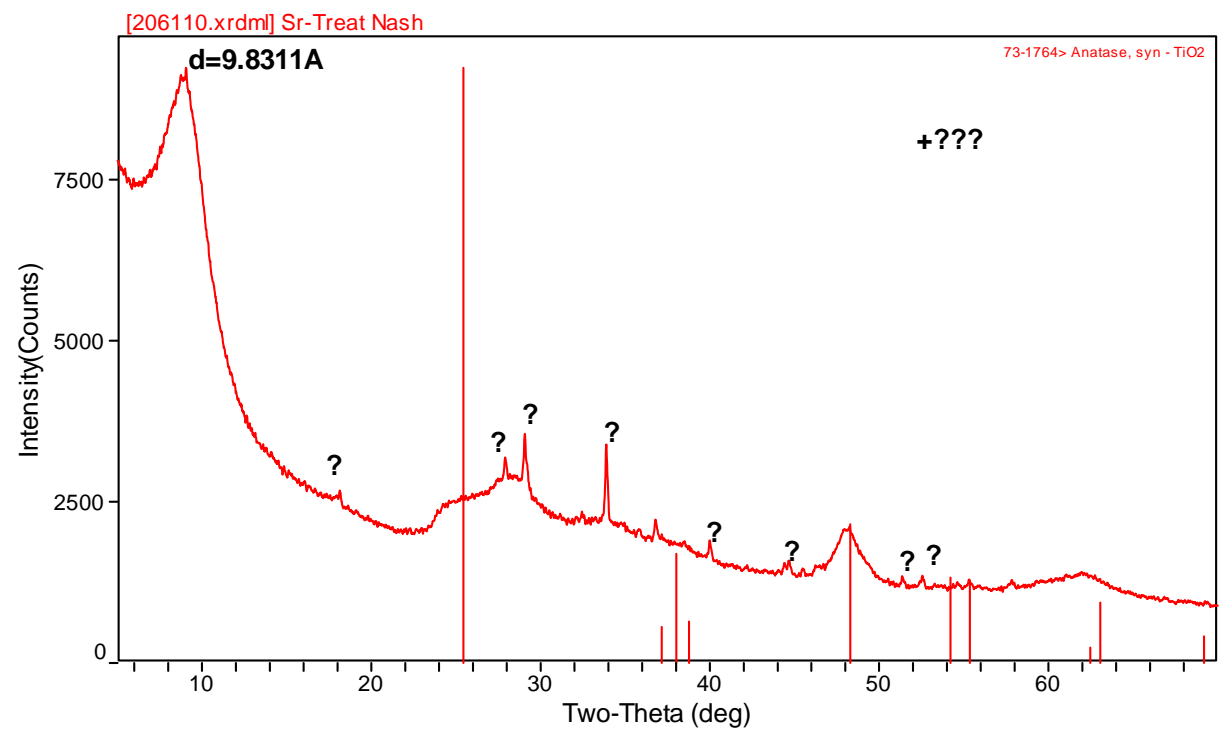

Figure 3. X-ray Diffraction Data for SrTreat ${ }^{\circledR}$ Adsorbent

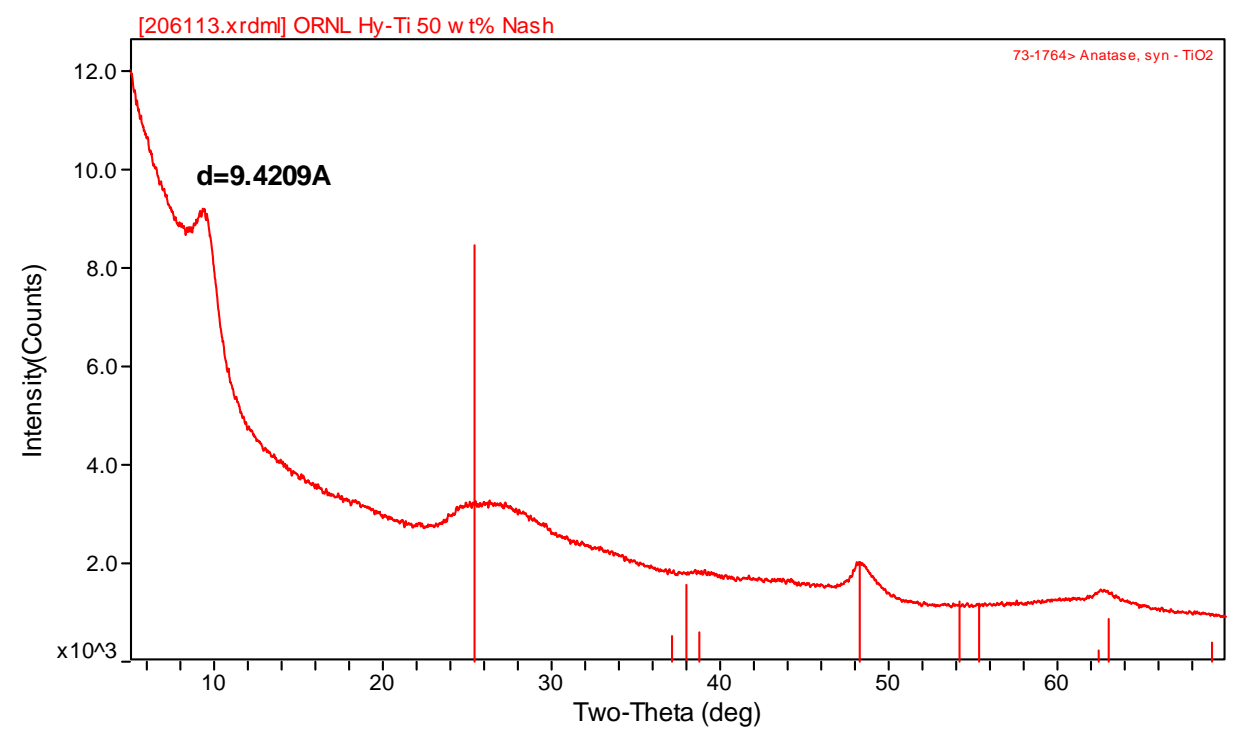

Figure 4. X-ray Diffraction Data for ORNL 50 wt \% MST Adsorbent Beads 


\subsection{Chemical Stability Testing}

Two levels of chemical stability testing were performed with all samples. Initially we contacted gram quantities of each sample with an alkaline salt solution in glass vials. We made qualitative observations noting physical changes like disintegration or growth of crystals and also caking, which is observed by checking to see if the particles flow when tilting the vial.

The qualitative chemical stability testing worked well to cast doubt on the consideration of several materials for use in engineering MST. Particles of Florisil ${ }^{\circledR}$, a porous magnesium silicate, were found to fuse together after only days of soaking in a beaker of alkaline salt solution. This substrate was thus quickly rejected from consideration.

The phosphate-bearing cements magnesium aluminum phosphate and calcium phosphate (hydroxyapatite) exhibited an unacceptable crystal-forming phenomenon on soaking. The effect was only visible after several months. While breakup of the cement particles was not obvious, crystals were found to be growing on the outside of the particles.

Figures 5 and 6 show the needle-like crystals recovered from the vials. XRD revealed that the crystals were trisodium phosphate hydrate. This salt would likely plug equipment in plant operations. This test therefore cast doubt on the use of these cements for engineering adsorbents. These results also predict that use of bone char, with its hydroxyapatite active component, should pose the same risk upon use in a waste pretreatment plant.

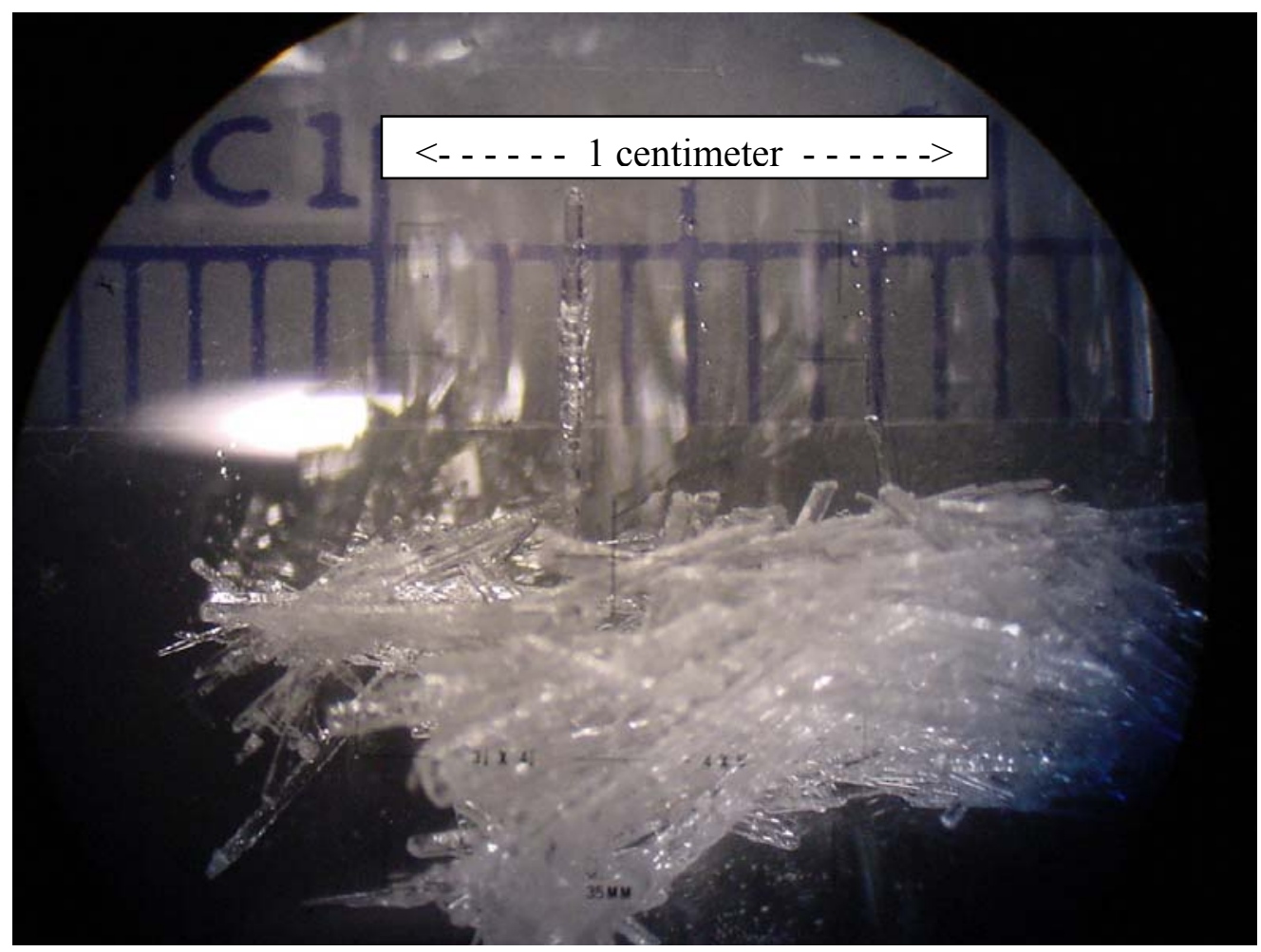

Figure 5. Crystals from Soaking Hydroxyapatite Cement in Simulant 


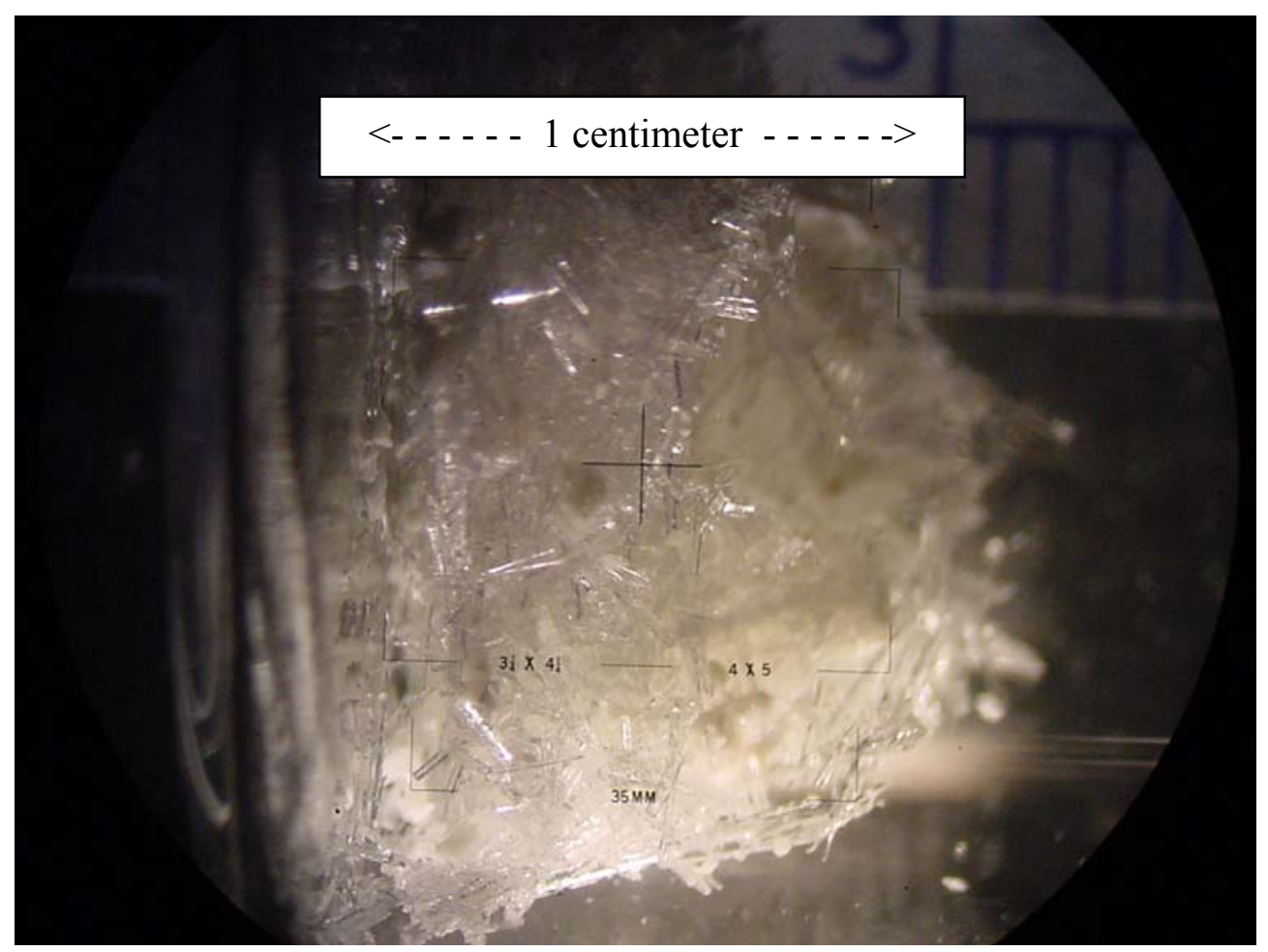

\section{Figure 6. Crystals from Soaking Mg/Al/PO4 Cement in Simulant}

A more quantitative method involved soaking 5-10 grams of solids in $150 \mathrm{~mL}$ of salt solution and observing changes in particle size with time using a Lasentec FBRM ${ }^{\circledR}$ instrument, Model M400L. The quantities of solid and liquid were chosen to be reasonable minimums that would allow solids agitation and reading by the Lasentec ${ }^{\circledR}$ probe. Sample particle size was measured within 4 hours of introduction of solids into the liquid and also again 7 and 52 days after introduction.

Table 3 shows that all of the MST-containing engineered materials exhibited good physical stability with the possible exception of the magnesium-aluminum phosphate cement. Outside of that sample the mean particle chord lengths were within the 250 to 595 micron desired range meaning that most of the solid volumes were in particle sizes at least the mean size. The table shows the square-weighted mean chord lengths in microns over time. Square weighting favors behavior of the larger particles; these tabulated data are not overly influenced by the effect of a few fines. Chord length refers to length of a line measured by scanning particles with a fine laser beam from the Lasentec ${ }^{\circledR}$ instrument. 
Table 3. Square-Weighted Mean Particle Chord Length, Microns, Over Time

\begin{tabular}{|l|c|c|c|}
\hline Engineered Sample & Initial & Day 7 & Day 52 \\
\hline UOP Beads & 436 & 432 & 475 \\
\hline ORNL 50 wt \% MST Beads & 527 & 524 & 534 \\
\hline SrTreat $^{\circledR}$ & 422 & 383 & 437 \\
\hline ORNL 32 wt \% MST Beads & 420 & 449 & 459 \\
\hline Mg-AOP Cement & 291 & 241 & 249 \\
\hline Al-Si Batch 1 Cement & 391 & 380 & 421 \\
\hline Al-Si Batch 2 Cement & 430 & 416 & 432 \\
\hline Hydroxyapatite Cement & 301 & 303 & 331 \\
\hline Internal Hydrolysis Batch 1 & 430 & 417 & 438 \\
\hline New Internal Hydr. Batch 2 & 437 & 414 & 431 \\
\hline K28 Fbrck Internal Hydrol. & 412 & 395 & 430 \\
\hline
\end{tabular}

\subsection{Salt Solutions for Batch Contact Testing}

The work used the salt simulant solution of Table 4 for all spiked simulant testing. This simulant recipe has been used uniformly for much work with MST at SRNL in the past. ${ }^{56}$

Table 4. Composition of the Salt Simulant

\begin{tabular}{|l|c|}
\hline Component & Molarity \\
\hline Free hydroxide & 1.33 \\
\hline Nitrate & 2.60 \\
\hline Aluminum (as aluminate) & 0.429 \\
\hline Nitrite & 0.134 \\
\hline Sulfate & 0.521 \\
\hline Carbonate & 0.026 \\
\hline Total Sodium & 5.60 \\
\hline
\end{tabular}

Table 5 presents the ${ }^{239} \mathrm{Pu} /{ }^{240} \mathrm{Pu}$ and ${ }^{237} \mathrm{~Np}$ data for the simulant for indicated number of days after makeup. All soluble species entries are in microgram/L.

Table 5. Actinide Levels in the Salt Simulant, microgram/L

\begin{tabular}{|c|c|c|c|c|c|c|}
\hline Time (d) & $\begin{array}{c}{ }^{2340} \mathbf{P u} / \\
\left.{ }^{240} \mathbf{P u}\right]\end{array}$ & $\begin{array}{c}\left.{ }^{240} \mathbf{P u} \mathbf{P u}\right] \\
\text { Target }\end{array}$ & {$[\mathbf{N p ]}$} & $\begin{array}{c}\text { [Np] } \\
\text { Target }\end{array}$ & [U] & [U] \\
\hline 0 & $179(13.9)$ & 200 & $530(22.9)$ & 500 & & \\
\hline 11 & $197(15.3)$ & 200 & $549(25.0)$ & 500 & & \\
\hline 27 & $194(15.1)$ & 200 & $568(21.3)$ & 500 & & \\
\hline 48 & $211(10.0)$ & 200 & $508(46.0)$ & 500 & $12,500(2,500)$ & 10,000 \\
\hline
\end{tabular}

Values in parentheses are standard estimates of error. 
The tank composite solution consisted of supernate samples from Tanks $11 \mathrm{H}, 30 \mathrm{H}, 32 \mathrm{H}$ and $39 \mathrm{H}$. We diluted the composite material to $5.8 \mathrm{M}$ in sodium using $1.66 \mathrm{M} \mathrm{NaOH}$ solution. The composite also contained $9,350 \mathrm{mg} / \mathrm{L}$ aluminum. The diluted composite was allowed to stand while changes in radiochemical analyses were noted. Table 6 displays the key analytical data over 48 days.

Table 6. Key Radioactive Element Levels in the Tank Composite Salt Solution

\begin{tabular}{|c|c|c|c|c|}
\hline $\begin{array}{l}\text { Time (d) } \\
\text { after } \\
\text { compositing }\end{array}$ & $\begin{array}{c}\text { [Total Pu], } \\
\text { microg/L }\end{array}$ & $\begin{array}{c}\left.{ }^{\mathbf{2 3 9}} \mathbf{P u} /{ }^{240} \mathbf{P u}\right], \\
\text { microg/L }\end{array}$ & {$\left[{ }^{\mathbf{9 0}} \mathrm{Sr}\right], \mathbf{d p m} / \mathbf{m L}$} & [U], mg/L \\
\hline 2 & $105 .(6.6 \%)$ & $94 .(6.9 \%)$ & $3.83 \mathrm{E}+06(7.8 \%)$ & $3.0(9.6 \%)$ \\
\hline 9 & $102 .(8.0 \%)$ & $91 .(8.4 \%)$ & $3.96 \mathrm{E}+06(7.8 \%)$ & $2.6(12.7 \%)$ \\
\hline 21 & $89 .(8.3 \%)$ & $78 .(8.8 \%)$ & $3.97 \mathrm{E}+06(7.8 \%)$ & $2.6(18.1 \%)$ \\
\hline 21 filtered & $52 .(12.0 \%)$ & $47 .(12.8 \%)$ & $1.01 \mathrm{E}+06(8.2 \%)$ & $2.1(22.8 \%)$ \\
\hline 32 & $90 .(13.8 \%)$ & $81 .(14.8 \%)$ & $1.51 \mathrm{E}+06(7.5 \%)$ & \\
\hline 48 & $98 .(6.6 \%)$ & $88 .(6.9 \%)$ & $3.88 \mathrm{E}+06(8.2 \%)$ & \\
\hline 48 filtered & $64 .(9.1 \%)$ & $58 .(9.6 \%)$ & $1.23 \mathrm{E}+06(8.2 \%)$ & \\
\hline
\end{tabular}

Percentages in the cells are standard estimates of error

\subsection{Batch Contact Procedures}

The batch contact procedure for this work was closely aligned with past procedures for MST except that batches of engineered material required a change in the sampling procedure. ${ }^{56}$ To provide the typical phase ratio of $2,500 \mathrm{~mL} / \mathrm{g}$ or $0.4 \mathrm{~g}$ of sorbent per liter, $250 \mathrm{~mL}$ of salt solutions were contacted with sorbent having the equivalent of $0.1 \mathrm{~g}$ MST. Researchers used $500 \mathrm{~mL}$ bottles to provide sufficient headspace for good agitation of each batch at the shaker cycle rate of $175 \mathrm{rpm}$. Oven shaker temperature was controlled to $27+/-2{ }^{\circ} \mathrm{C}$ and was monitored by both the oven thermocouple and a separate calibrated thermocouple. SRNL operations monitored and recorded temperature in the off-hours.

Technicians sampled the batches at least a half hour after agitation was stopped to allow settling of the engineered materials. They withdrew approximately $5 \mathrm{~mL}$ of salt solution, filtered it through 0.45 micron nylon syringe tip filters, and pipetted $4 \mathrm{~mL}$ of the filtrate into $4 \mathrm{~mL}$ of $5 \mathrm{M}$ nitric acid. They agitated the mixtures and allowed at least 2 hours of time before processing the samples further to allow complete acid dissolution. Three $\mathrm{mL}$ of acidified filtrate were measured into gamma vials for counting. Five $\mathrm{mL}$ were provided separately to ADS for Pu TTA and strontium-85 gamma counting.

For tests in the Shielded Cells with actual tank wastes, we agitated the contents of test bottles using a five-station magnetic stirrer and small Teflon ${ }^{\circledR}$ magnet bars. Batch bottles in cells work were $250 \mathrm{~mL}$ because headspace was not needed for good agitation. A water bath at $27 \pm 2{ }^{\circ} \mathrm{C}$ provided temperature stability. Technicians measured 1.5 grams of filtrate into $60 \mathrm{~mL}$ plastic sample bottles containing pre-measured $25 \mathrm{~mL}$ portions of $3 \mathrm{M}$ nitric acid. Acidified filtrate 
samples sat for more than two hours before further sample pouring and cell exit for chemical and radiochemical analyses.

\subsection{Results of Batch Contacts}

Batch contact testing provides data on relative kinetics, an equilibrium point on the isotherm, and, depending on phase ratio, an estimate of sorbent capacity. The analyses for testing here covered sorption of strontium, plutonium, and neptunium. The basic parameters for handling batch contact data are initial and final concentrations of adsorbates, mass of adsorbent, and volume of solution. Decontamination factor (DF) is calculated with the following equation.

$$
\mathrm{DF}=(\text { initial concentration }) /(\text { final concentration })
$$

Distribution coefficient $\mathrm{K}_{\mathrm{d}}$ is found by the following equation.

$$
\mathrm{K}_{\mathrm{d}}=(\mathrm{DF}-1) *(\text { solution volume }) /(\text { mass of sorbent })
$$

Specific sorbent loading is calculated as shown below.

$$
\begin{aligned}
\text { Loading } & =(\text { initial concentration }- \text { final concentration }) *(\text { volume }) /(\text { mass of sorbent }) \\
& =\mathrm{K}_{\mathrm{d}} *(\text { initial concentration })
\end{aligned}
$$

At very high phase ratio there is very little sorbent for each volume of solution. The sorbent sees the greatest opportunity to be loaded near capacity. Since this condition represents the top of an ion exchange column bed (downflow assumed), such a batch contact would allow estimation of process loading.

\subsubsection{Spiked Simulant Testing with Engineered MST Samples}

The first set of batch contacts with spiked simulant used the quantities of materials given in Table 7. Note that when a sample name has "\#1" and "\#2" researchers performed duplicate batch contacts on that material. The ORNL $50 \mathrm{wt} \%$ and $32 \mathrm{wt} \% \mathrm{MST}$ materials are considered to be separate samples despite the same process to produce them. The change in MST content appeared to greatly change the appearance and porosity between the materials as noted before.

Prior to sorption performance all of the engineered MST samples were pre-soaked in an unspiked salt solution for approximately 116 hours at room temperature. The samples were removed from the soak solutions and immediately added to the appropriate test bottle. 
Table 7. Sample Masses Containing 0.1 grams MST Equivalent for Batch Contacts

\begin{tabular}{|l|r|}
\hline \multicolumn{1}{|c|}{ Sample } & \multicolumn{2}{c|}{$\begin{array}{c}\text { Sample Mass, } \\
\text { grams }\end{array}$} \\
\hline MST & 0.1 \\
\hline SrTreat $^{(\mathbb{}} \# 1$ & 0.1154 \\
\hline SrTreat $^{\mathbb{B}} \# 2$ & 0.1153 \\
\hline Control & zero \\
\hline UOP Bead \#1 & 0.1268 \\
\hline UOP Bead \#2 & 0.1273 \\
\hline UOP Trilobe & 0.124 \\
\hline ORNL 50 wt \% \#1 & 0.1997 \\
\hline ORNL 50 wt \% \#2 & 0.2 \\
\hline ORNL 32 wt \% & 0.3126 \\
\hline Mg-AOP & 0.252 \\
\hline Alum-Silicate & 0.2609 \\
\hline Hydroxyapatite & 0.3998 \\
\hline Clemson & 0.6167 \\
\hline Inter Hydrolysis & 1.0035 \\
\hline
\end{tabular}

We measured the concentration of ${ }^{239} \mathrm{Pu} /{ }^{240} \mathrm{Pu}$ in the solutions after $1,4,7$, and 10 days of contact. Figure 7 provides a plot of the plutonium concentrations versus time for each of the tested materials. The results indicate that MST and the internal hydrolysis sample exhibited the best removal kinetics. SrTreat ${ }^{\circledR}$ and the ORNL $50 \mathrm{wt} \%$ beads were good performers though kinetics were slower. The aluminosilicate material also did well. The other materials were relatively poor performers. 


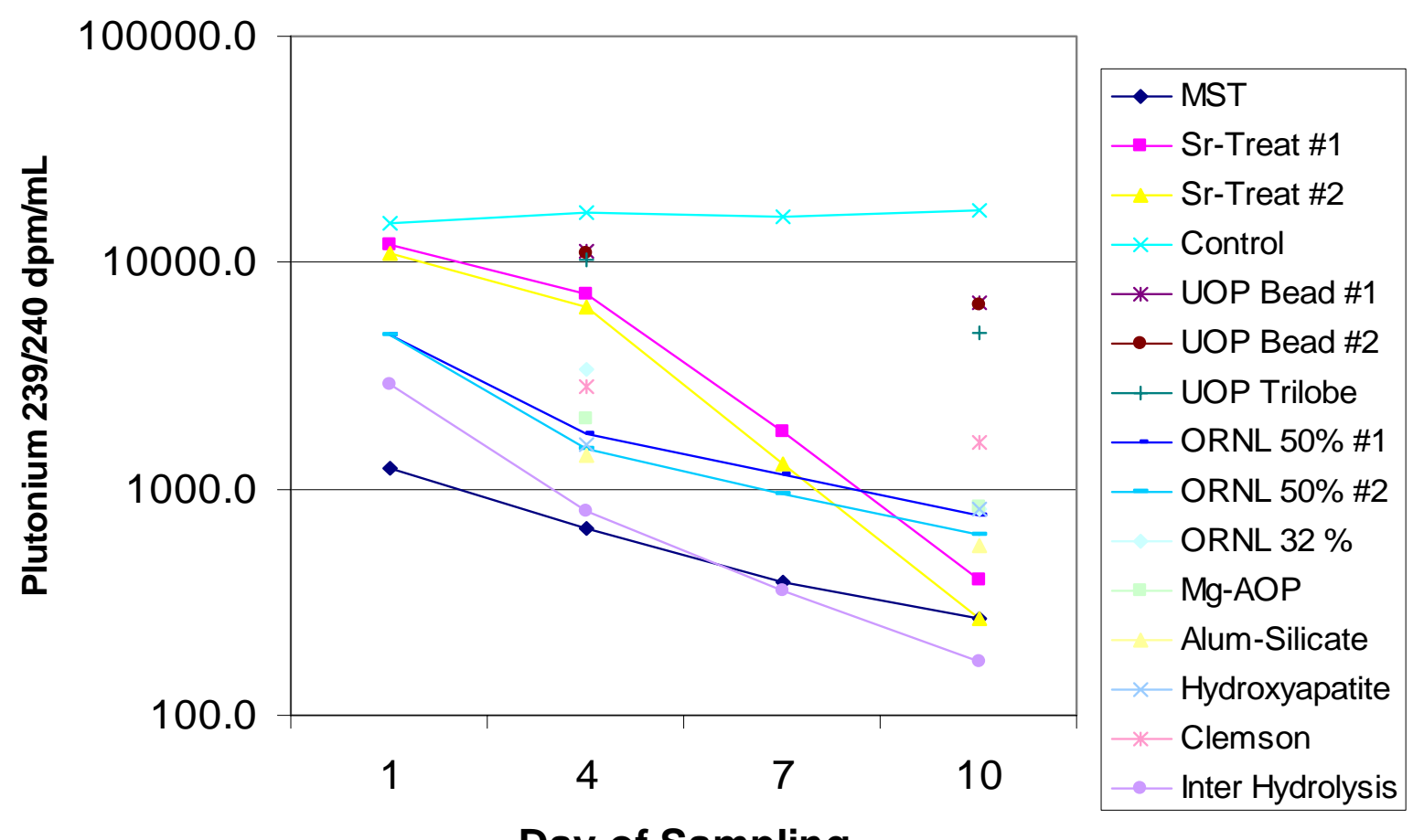

\section{Day of Sampling}

Figure 7. Soluble Plutonium versus Time for the First Batch Contacts

Corresponding decontamination factors on the tenth day of the batch contact work are shown in Figure 8 below. The relatively high value for the internal hydrolysis sample demonstrated that the MST created in the pores of the substrate was of good quality.

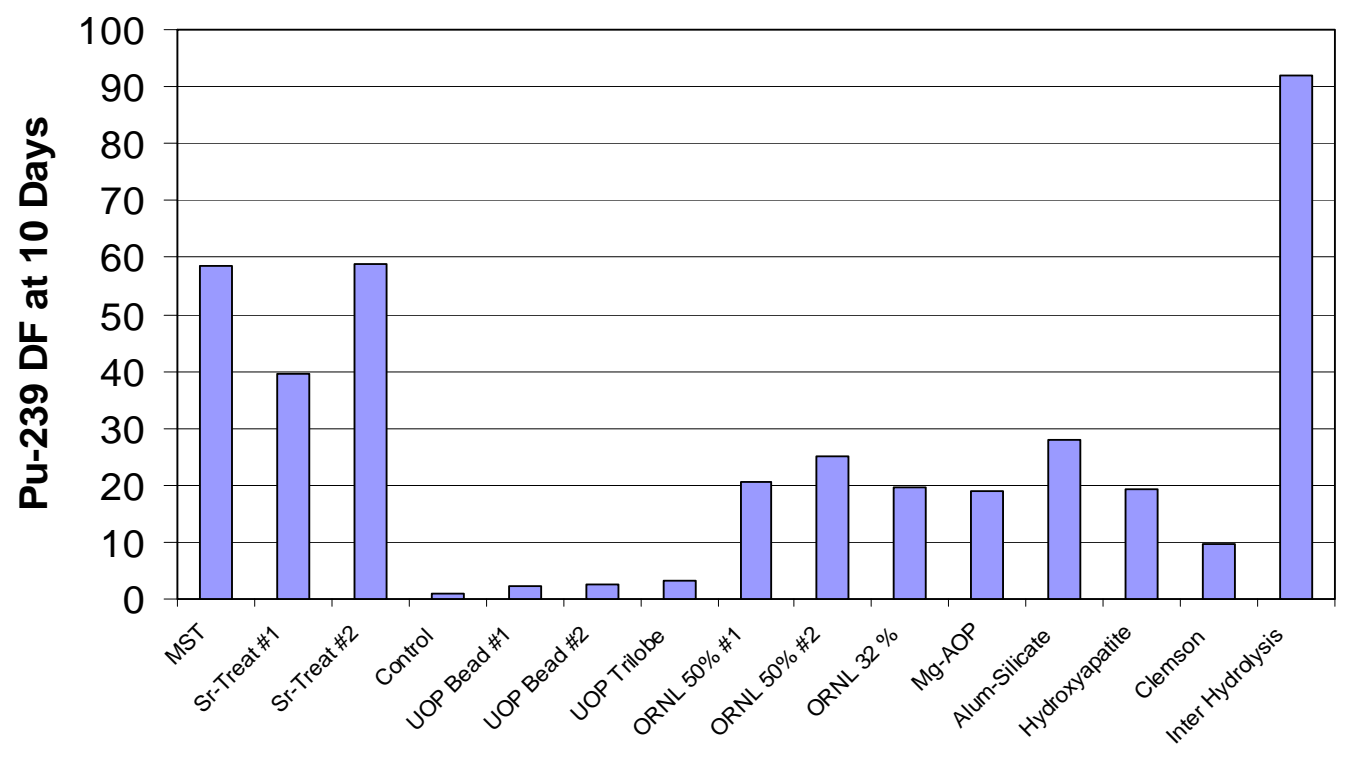

Engineered Material

Figure 8. Plutonium Decontamination Factors for the First Batch Contacts 
Distribution coefficients are shown in Figure 9 below. The calculation used the total adsorbent mass in each case and therefore penalized materials which have low MST content. This effect is most pronounced with the internal hydrolysis sample. The DF for the internal hydrolysis sample measured approximately 50\% greater than the MST and SrTreat ${ }^{\circledR}$ samples. However, the $\mathrm{K}_{d}$ value is about $3-5$ times lower than that of the MST and SrTreat ${ }^{\circledR}$ samples.

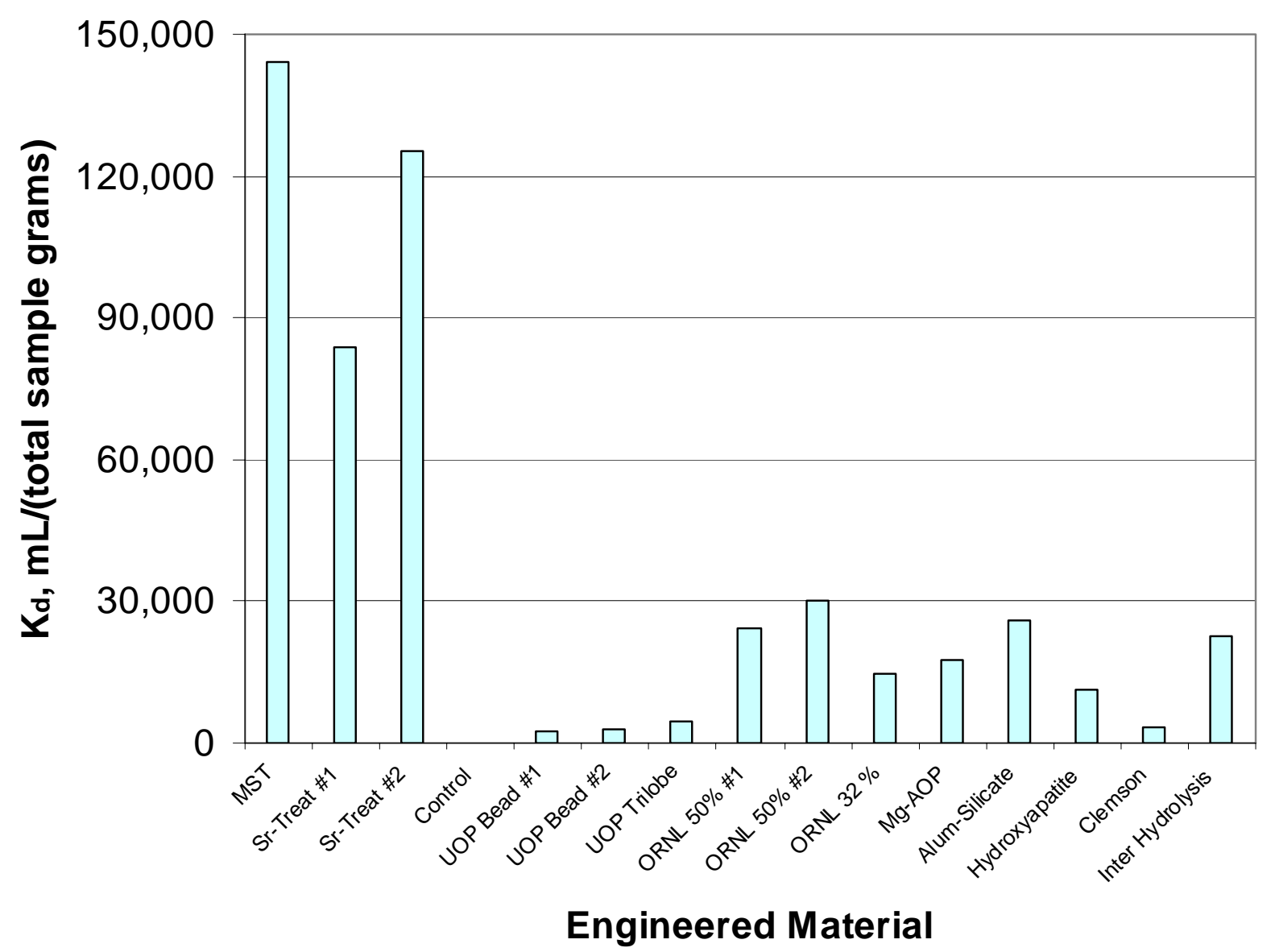

\section{Figure 9. Plutonium Distribution Coefficients for the First Batch Contacts}

Strontium-85 gamma counting by the ADS of SRNL provided data for all samples on days 4 and 10. The first four samples in the above table plus the duplicate ORNL $50 \mathrm{wt} \%$ samples and the internal hydrolysis sample were also counted on day 1 and 7 . Time-corrected ${ }^{85} \mathrm{Sr}$ activity for the control was $10873+/-760 \mathrm{dpm}$ per 3-mL vial. Figure 10 below shows decontamination factor (DF) data. Figure 11 only shows the results of the seven aforementioned samples measured four times because these were considered the most important.

Differences in peak height in Figure 10 are indicators of approach to equilibrium. MST reached equilibrium by day 4 as expected. Best performers for strontium were SrTreat ${ }^{\circledR}$, the ORNL 50 wt \% MST beads, the aluminosilicate bound MST, and the internal hydrolysis sample. 
Figure 11 shows rate of approach to equilibrium. The control sample was steady as already indicated. The MST and internal hydrolysis samples exhibited the best kinetics. The kinetics of the other samples were slower. The UOP Bead \#1 exhibited the slowest kinetics.

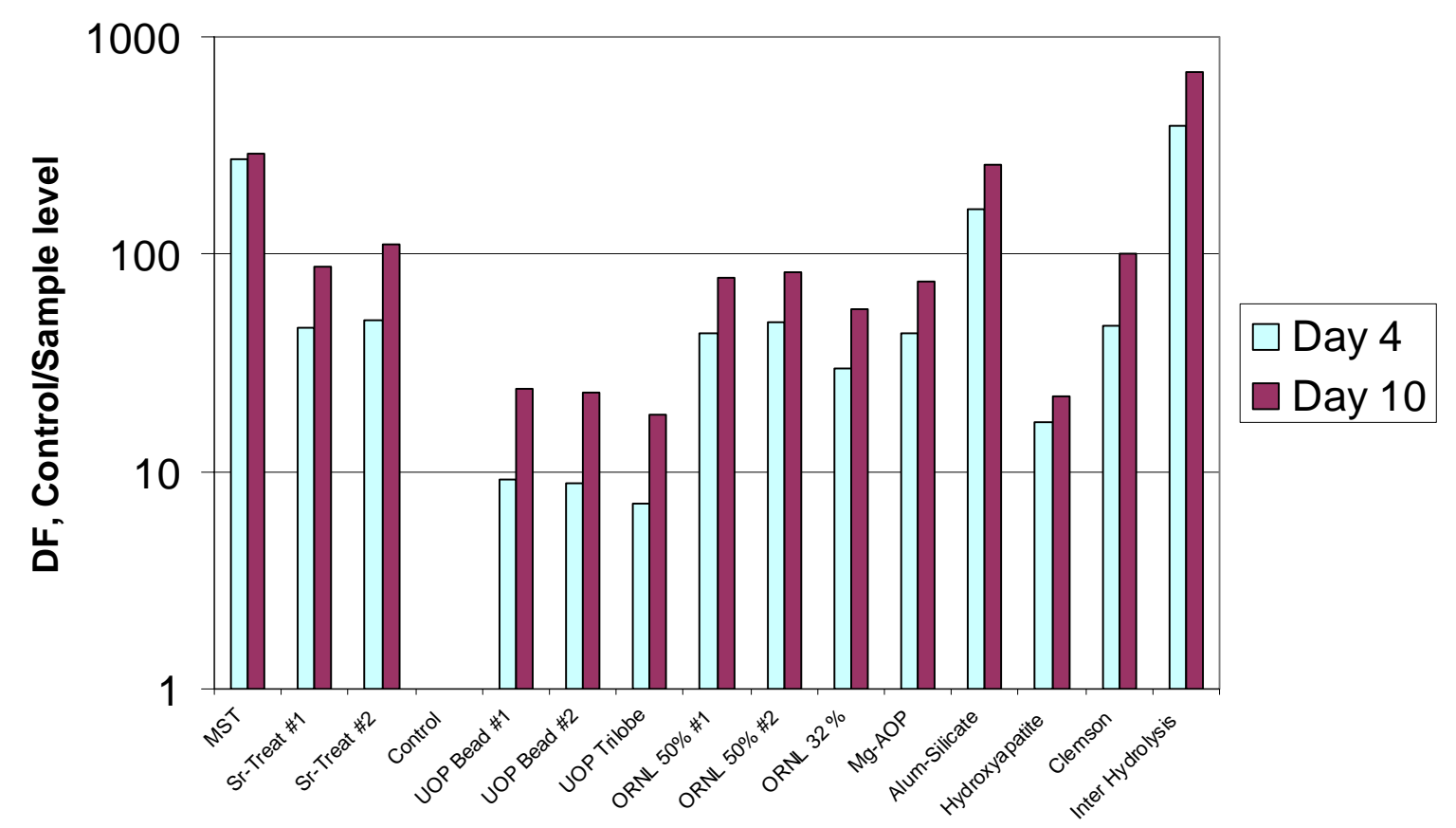

Engineered Material

Figure 10. Strontium-85 Decontamination Factors from Spiked Simulant Batch Contacts

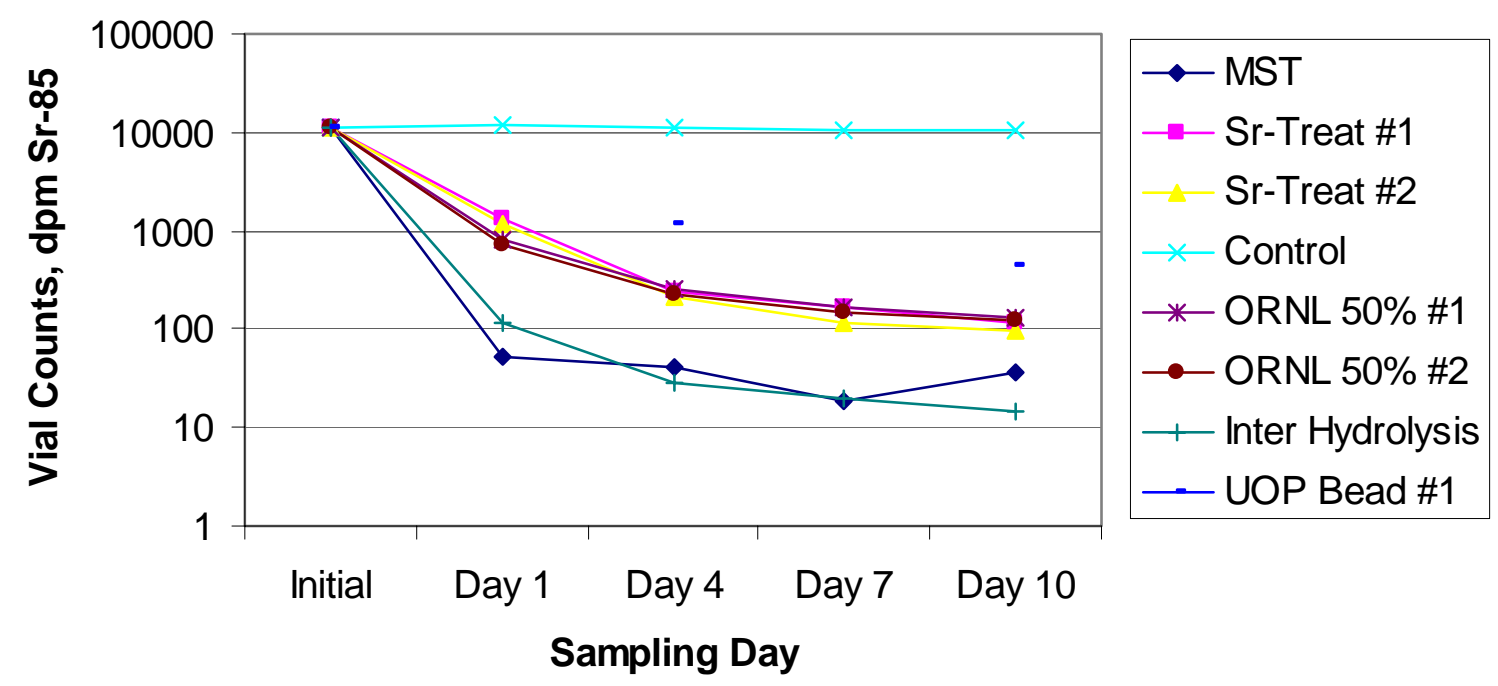

Figure 11. Time Dependence of Strontium Decontamination 
Figure 12 shows that the ORNL $50 \mathrm{wt} \%$ MST beads clearly perform best of all the adsorbents for neptunium removal. They provided a better DF than the baseline MST material. SrTreat ${ }^{\circledR}$ did well though all the best-performing materials demonstrated strong kinetics effects between the 4 and 10 day measurements.

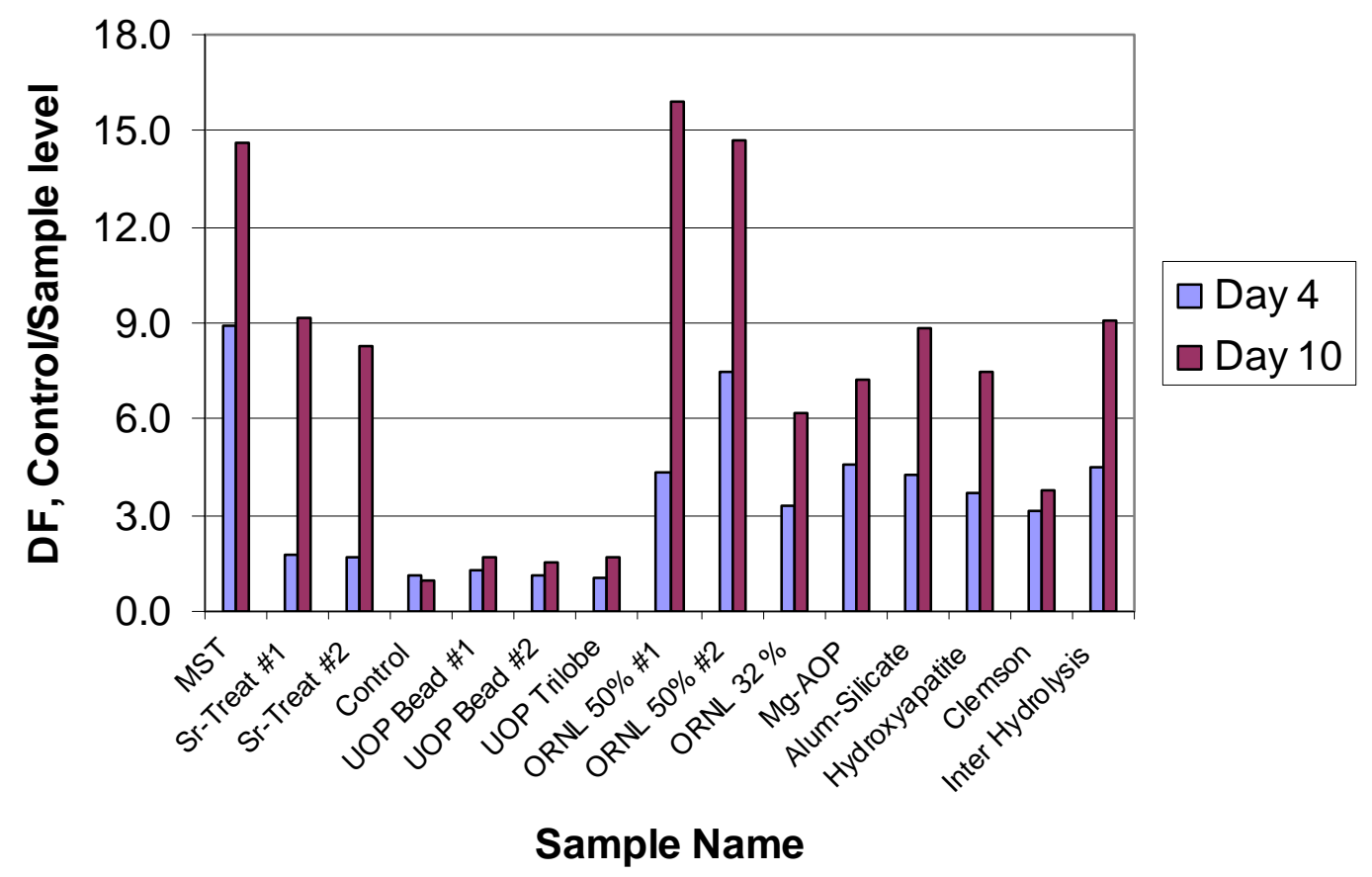

Figure 12. Neptunium-237 Decontamination Factors from Spiked Simulant Batch Contacts

\subsubsection{Actual Tank Composite Tests with Three Engineered Materials}

The testing performed batch contacts of selected materials using an actual tank waste composite to verify results from spiked simulant work. The tank composite consisted of supernate samples from Tanks $11 \mathrm{H}, 30 \mathrm{H}, 32 \mathrm{H}$ and $39 \mathrm{H}$. After combining the supernate samples, we diluted the composite material to $5.6 \mathrm{M}$ in sodium using $1.66 \mathrm{M} \mathrm{NaOH}$ solution. The diluted composite was allowed to stand until radiochemical analyses confirmed that plutonium and strontium concentrations were no longer changing.

We assembled the batch contact tests with $250 \mathrm{~mL}$ portions of tank waste composite and $0.1 \mathrm{~g}$ of MST or its equivalent with the ORNL $50 \mathrm{wt} \%$ MST beads (in duplicate), Sr-Treat ${ }^{\circledR}$, and one internal hydrolysis sample. There was a control bottle containing only composite solution. Bottles were agitated with small magnetic stir bars agitated batch bottle contents in Cell 3 and temperature was controlled to $27 \pm 2{ }^{\circ} \mathrm{C}$ with a water bath.

Figure 13 shows that the ORNL $50 \mathrm{wt} \%$ MST beads were superior to the other adsorbents for plutonium removal after 10-day batch contacts. Figure 13 shows distribution coefficients which 
when multiplied by bed density provide an order of magnitude estimate of column capacity (bed volumes to breakthrough). Density for the material is $0.99 \mathrm{~g} / \mathrm{mL}$ per Table 2 , so a column of ORNL $50 \mathrm{wt} \%$ MST beads would be expected to process at least 28,000 bed volumes of actual waste before breakthrough if operated sufficiently slowly. Batch contact testing does not provide column kinetics data so column runs would be needed to determine sufficiently slow flowrate that will provide a sharp breakthrough.

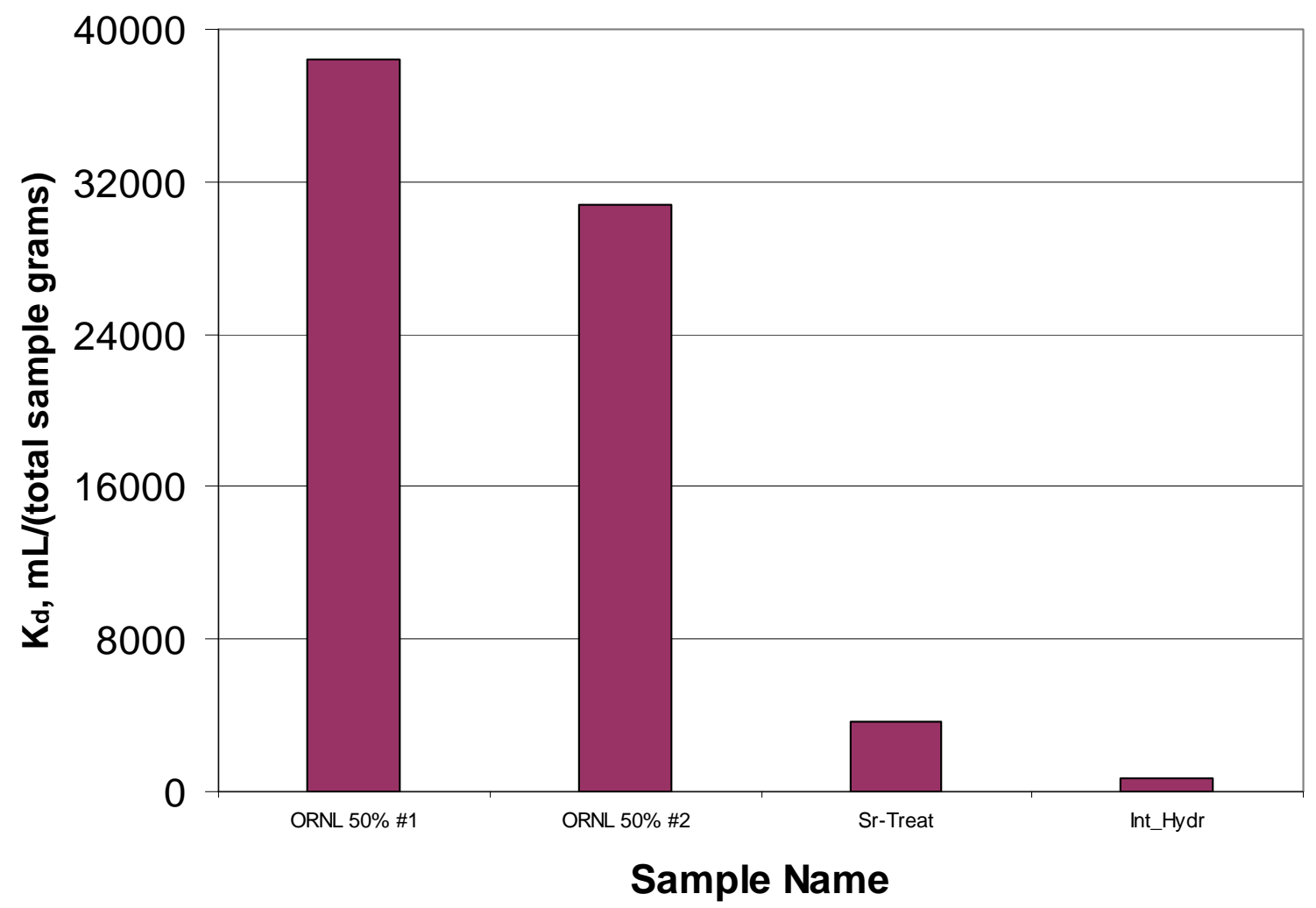

Figure 13. Plutonium Distribution Coefficients from Actual Waste Batch Contacts

Figure 14 shows strontium performance, also in terms of batch distribution coefficient. It is clear in comparing data from Figures 13 and 14 that a column would always break through first for plutonium long before it would break through for strontium. All of these materials demonstrate that strontium decontamination is easy to achieve and is not limiting.

The actual waste batch contacts yielded no neptunium data because there was too little neptunium in the waste to measure. 


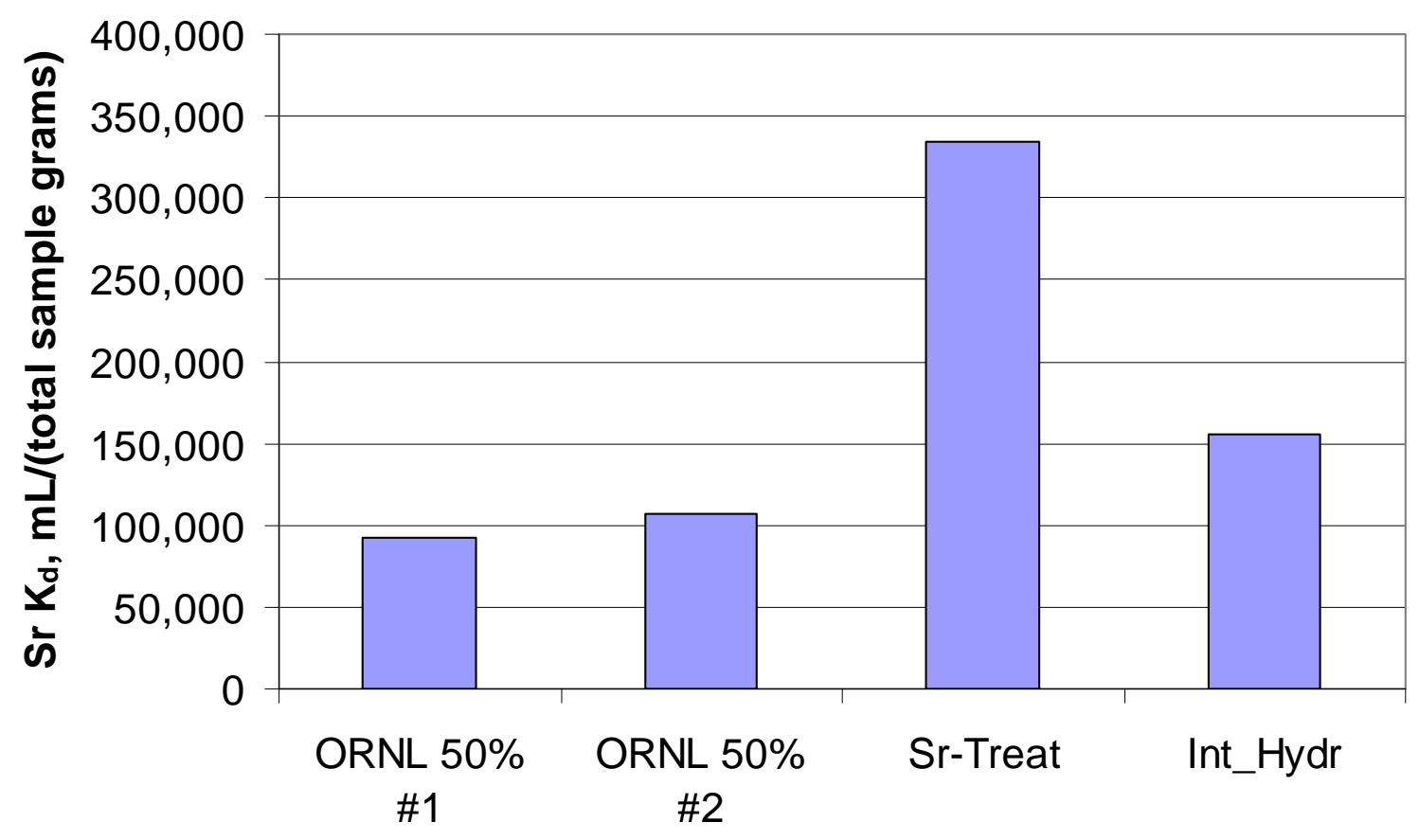

Sample Type

\section{Figure 14. Strontium Decontamination from Actual Waste Batch Contacts}

\subsubsection{Spiked Simulant Testing with Selected Materials at a Phase Ratio of 25,000 mL/g}

This testing measured actinide removal at a very high phase ratio to provide a better estimate of the mass actinide loading on the engineered materials. This testing also examined the performance of additional internal hydrolysis samples made under conditions that should increase their MST loading.

Use of adsorbents in a column configuration leads to the need for adsorption isotherm data at feed levels of adsorbates. Knowledge of actinide loading at high or feed-level concentrations is needed primarily to determine adsorbent bed service life. Batch $\mathrm{K}_{\mathrm{d}}$ tests are only snapshots of points along the isotherm. High phase ratio tests best characterize adsorption at the top or inlet of the bed.

Little work with high equilibrium levels of actinides and MST has been done in the past. The highest phase ratio batch contact done in the past was approximately $20,000 \mathrm{~mL} / \mathrm{g}{ }^{57}{ }^{7}$ The difficulty in determining full loading of adsorbents is that actinides and strontium are sparingly soluble in alkaline high sodium solutions. Very high ratios of solution volume to adsorbent mass in batch contacts are therefore required to load the sorbent to near-feed levels of equilibrium. Limited available volumes of solution, accuracy of weighing small portions of adsorbent, and quantitative delivery of small amounts of adsorbents to the batch challenge the researcher. 
This set of batch contacts compared the performance of a second batch of Porocel ${ }^{\circledR}$ internal hydrolysis, K28 (now JM-28) firebrick internal hydrolysis at phase ratio 2,500 and 25,000 mL/g. In addition MST was run at the $25,000 \mathrm{~mL} / \mathrm{g}$ level $(0.04 \mathrm{~g} / \mathrm{L})$. Table 8 shows the adsorbent loadings for plutonium after 14 days. The DF's are much higher than unity in most cases, showing that even at the high phase ratio used here the adsorbents are not approaching their full capacity. This indicates that the capacity of MST for plutonium is unbounded by this work. If it were assumed that the maximum capacity of MST was at a Ti:Pu mole ratio of 4 consistent with $\mathrm{Pu}(\mathrm{VI})$ then the material could load to $25 \mathrm{wt} \% \mathrm{Pu}$. This would suggest that phase ratios exceeding a $10^{6} \mathrm{~mL} / \mathrm{g}$ or multiple contacts would assist in detecting the capacity for each sorbate.

Table 8. Second Set of Spiked Simulant Batch Contacts

\begin{tabular}{|l|r|r|r|r|r|}
\hline Adsorbent & $\begin{array}{l}\text { Adsorbent } \\
\text { mass, grams }\end{array}$ & $\begin{array}{l}\text { Equiv. MST } \\
\text { Mass, grams }\end{array}$ & $\begin{array}{l}\text { Phase ratio, } \\
\text { mL/gram }\end{array}$ & $\begin{array}{l}\text { Wt Percent } \\
\text { Pu Loading }\end{array}$ & $\begin{array}{l}\text { DF for Pu at } \\
\text { 14 Days }\end{array}$ \\
\hline MST & 0.0100 & 0.0100 & 25,000 & 0.252 & 19.4 \\
\hline $\begin{array}{l}\text { New } \\
\begin{array}{l}\text { Porocel }{ }^{\circledR} \text { Int. } \\
\text { Hydr. }\end{array}\end{array}$ & 0.7922 & 0.1000 & 2,500 & 0.026 & 101.8 \\
\hline $\begin{array}{l}\text { K28 (JM-28) } \\
\text { Firebrick }\end{array}$ & 0.8493 & 0.1000 & 2,500 & 0.026 & 33.7 \\
\hline $\begin{array}{l}\text { New } \\
\begin{array}{l}\text { Porocel }{ }^{\circledR} \text { Int. } \\
\text { Hydr. }\end{array}\end{array}$ & 0.0792 & 0.0100 & 25,000 & & \\
\hline $\begin{array}{l}\text { K28 (JM-28) } \\
\text { Firebrick }\end{array}$ & 0.0850 & 0.0100 & 25,000 & & \\
\end{tabular}

Figure 15 below shows the distribution coefficients for the engineered materials based on the 10day batch sample. $\mathrm{K}_{\mathrm{d}}$ for MST was not shown because it is $461,000 \mathrm{~mL} / \mathrm{g}$. Note that "high p" in the batch names refers to the $25,000 \mathrm{~mL} / \mathrm{g}$ phase ratio. The first samples beyond the control are at the $2,500 \mathrm{~mL} / \mathrm{g}$ phase ratio. The fact that the $\mathrm{K}_{\mathrm{d}}$ for the materials does not change much when the phase ratio was increased by a factor of 10 shows that the active adsorbent is still operating within the linear region of its isotherm. It is far from its full loading capacity. 


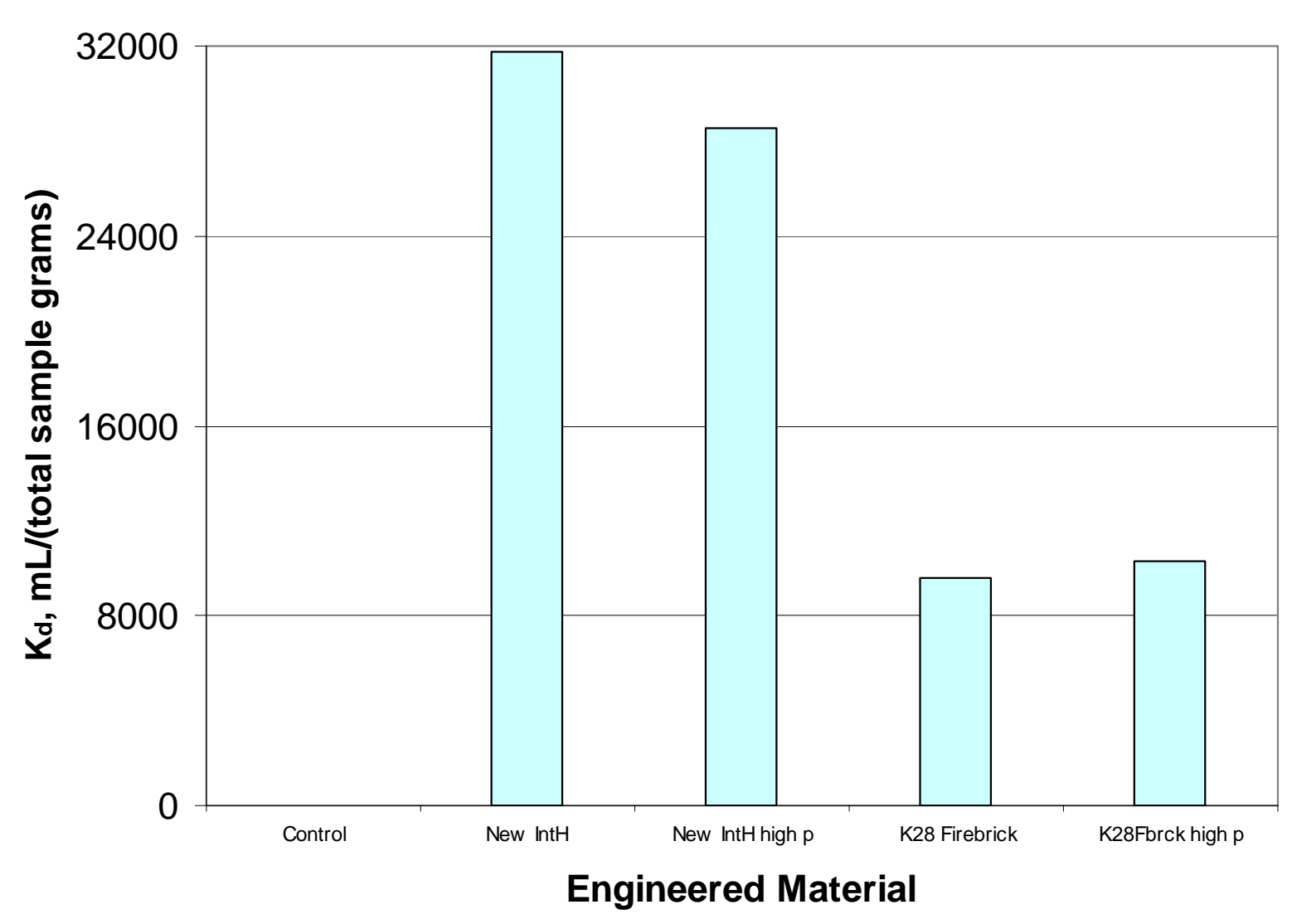

Figure 15. Plutonium Distribution Coefficients at Two Phase Ratios

Figure 16 below shows that all the materials worked well in removing strontium and that the Porocel Dynocel substrate made a better adsorbent than did the K28 (now JM-28) firebrick. These two materials did not differ much in MST loading. We attribute the difference to interference from elements in the K28 firebrick that are not present in the Porocel ${ }^{\mathbb{B}}$ alumina. The two samples were made by precipitation from the same batches of reagent solutions so the differences had to be from substrate effects. 


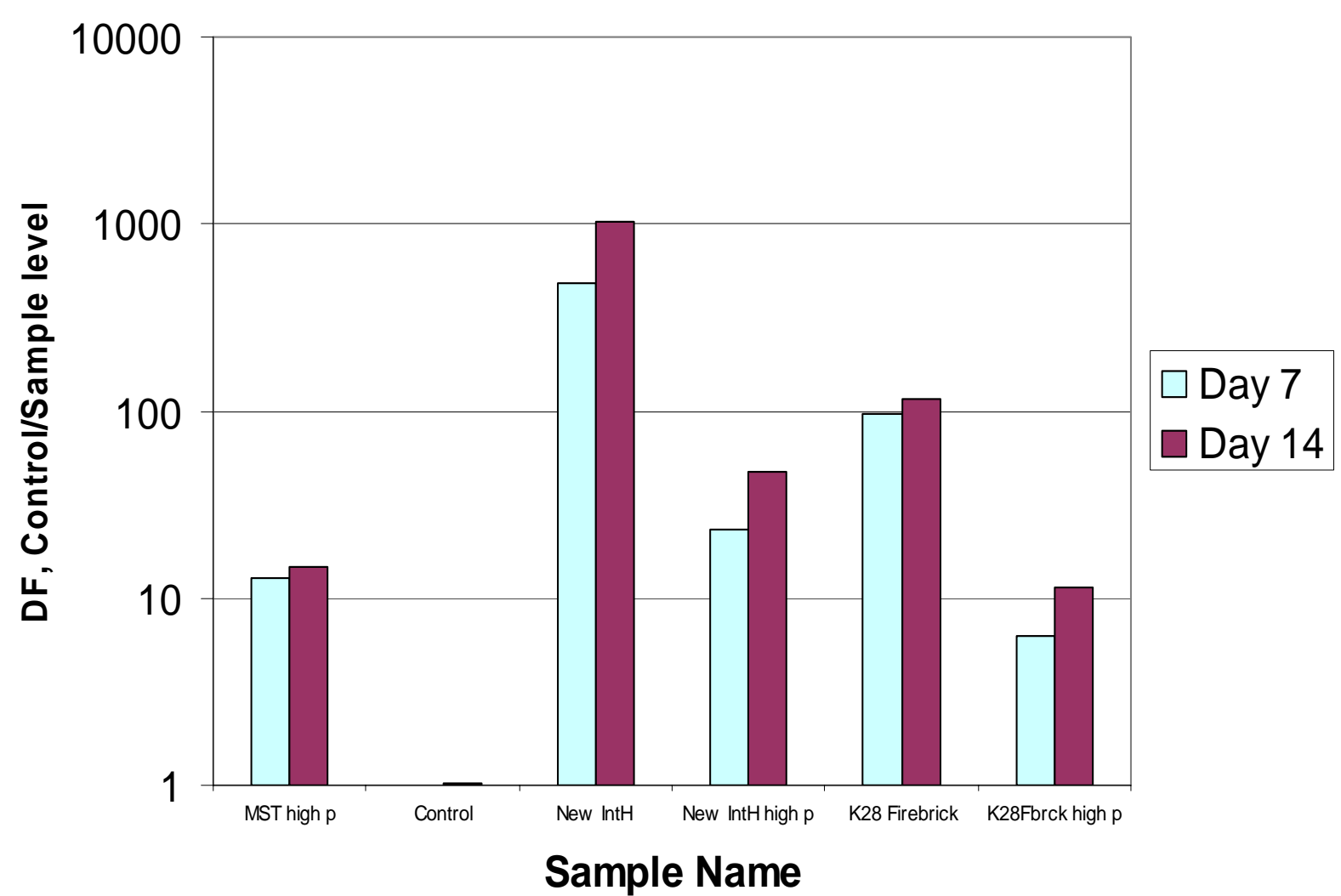

Figure 16. Strontium Decontaminations in the Second Set of Spiked Simulant Batch Contacts

\subsubsection{Uncertainties in Measurement and Solution Stability}

All batch contact testing included control solutions that were sampled at the times that other samples were taken. These multiple measurements provided overall uncertainty in the aging, sampling and dilution, and counting process. Table 9 below is a summary of the control solution measurements and uncertainties for the three sets of batch contacts. The simulant was re-spiked with $\mathrm{Sr}-85$ before the second set of batch contacts. Sr- 85 from the original spike had decayed significantly because of the 64 day half life of that isotope.

The tank composite did not have sufficient neptunium for useful measurements. There were no attempts to spike the composite. The waste needed sampling dilution unlike the spiked simulant because it contained about $1.3 \mathrm{E}+9 \mathrm{dpm} / \mathrm{mL}{ }^{137} \mathrm{Cs}$. Volumetic dilution factors were slightly over $20: 1$. 
Table 9. Activities and Total Error in Control Solutions

\begin{tabular}{|c|c|c|c|c|}
\hline Simulant $-1^{\text {st }}$ set & $\begin{array}{l}\text { Average } \\
\mathrm{dpm} / \mathrm{mL}\end{array}$ & $\begin{array}{l}\text { One Sigma } \\
\mathrm{dpm} / \mathrm{mL}\end{array}$ & $\begin{array}{l}\text { Percent } \\
\text { error }\end{array}$ & $\begin{array}{c}\text { Time span, } \\
\text { days }\end{array}$ \\
\hline${ }^{85} \mathrm{Sr}$ & 10873 & 760 & 7.0 & 43 \\
\hline${ }^{237} \mathrm{~Np}$ & 1071 & 156 & 14.6 & 43 \\
\hline${ }^{239} \mathrm{Pu} /{ }^{240} \mathrm{Pu}$ & 15820 & 1021 & 6.5 & 43 \\
\hline \multicolumn{5}{|l|}{ Simulant $-2^{\text {nd }}$ set } \\
\hline${ }^{85} \mathrm{Sr}$ & $1.34 \mathrm{E}+5$ & 2200 & 1.6 & 14 \\
\hline${ }^{237} \mathrm{~Np}$ & 908 & 272 & 30.0 & 14 \\
\hline${ }^{239} \mathrm{Pu} /{ }^{240} \mathrm{Pu}$ & 14450 & 1630 & 11.2 & 14 \\
\hline \multicolumn{5}{|l|}{ Tank Composite } \\
\hline${ }^{90} \mathrm{Sr}$ & $1.27 \mathrm{E}+6$ & $0.105 \mathrm{E}+6$ & 8.3 & 10 \\
\hline${ }^{237} \mathrm{~Np}$ & ND & & & \\
\hline${ }^{238} \mathrm{Pu}$ & $2.13 \mathrm{E}+5$ & $0.104 \mathrm{E}+5$ & 4.9 & 10 \\
\hline
\end{tabular}

\subsubsection{Comparison of Spiked Simulant and Actual Tank Composite Data}

Researchers performed tests with the first set of batch contacts with simulant and the actual tank composite work under similar conditions so that matrix effects could be seen. Samples were obtained under identical phase ratio, sample schedule, and temperature. Plutonium was near saturation in both cases. ${ }^{239} \mathrm{Pu} /{ }^{240} \mathrm{Pu}$ data from spiked simulant are comparable to ${ }^{238} \mathrm{Pu}$ data in the tank solution case because of the different major sources of plutonium.

Figures 17 and 18 below show how the ORNL $50 \mathrm{wt} \%$ MST beads performed consistently for both plutonium and strontium DF across the solutions for sample times of 4 and 10 days after commencement of batch contacting. The ORNL material performed slightly better in actual waste than it did in the simulant. 
WSRC-TR-2004-00286, Revision 0

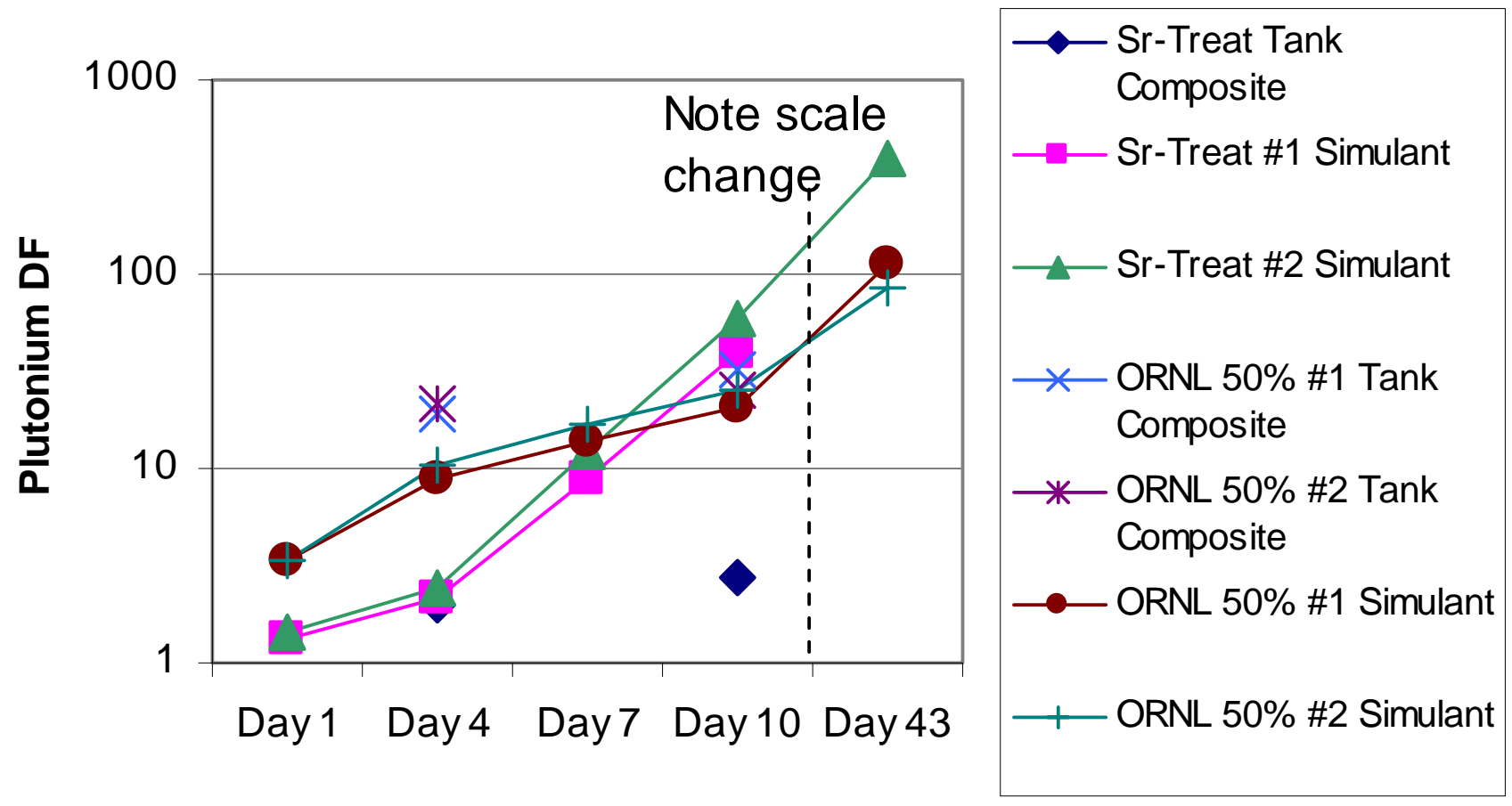

Figure 17. Comparison of Simulant vs. Actual Tank Composite Pu Adsorption for ORNL 50 wt \% Beads

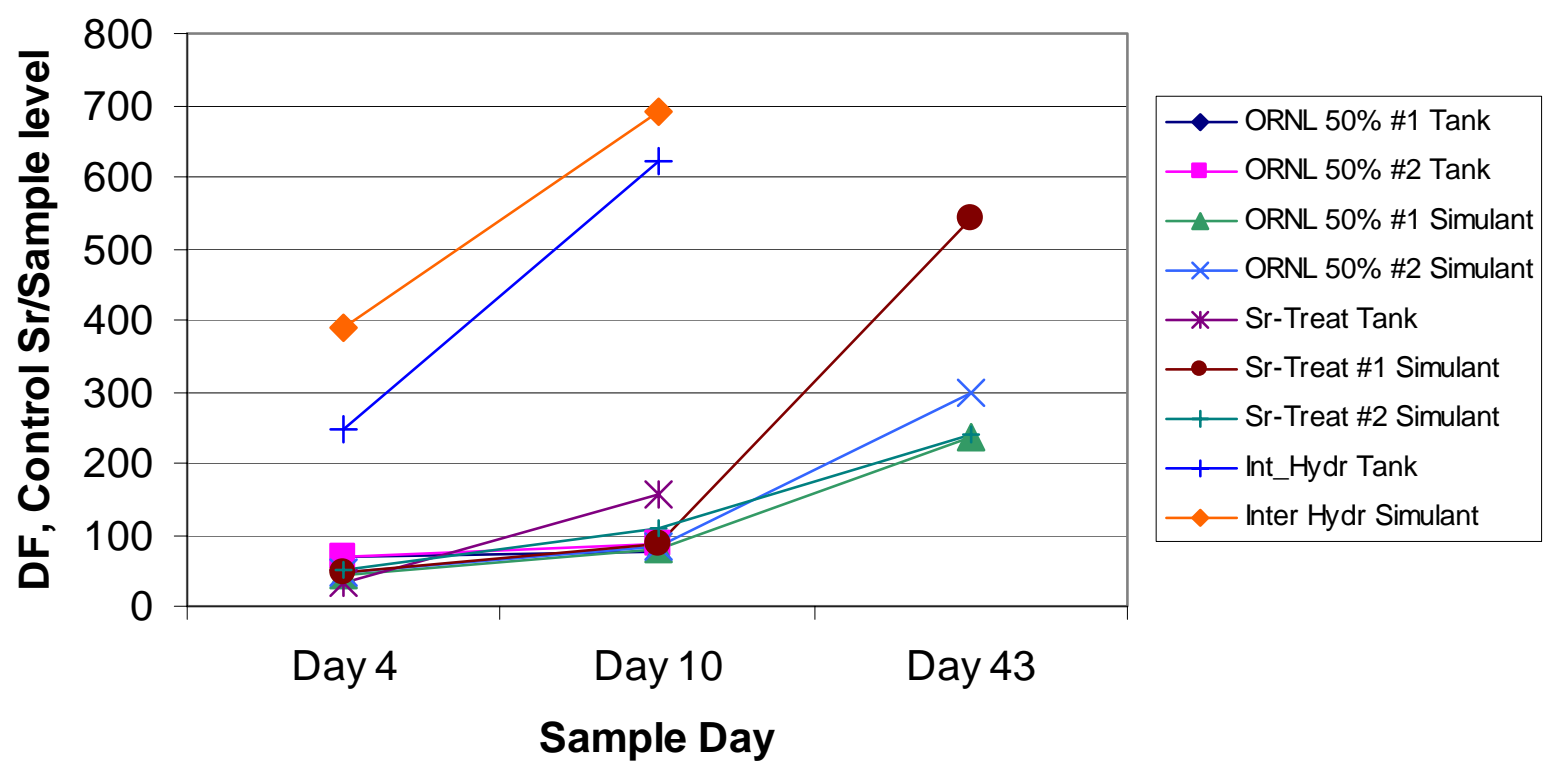

Figure 18. Comparison of Simulant vs. Actual Tank Composite Sr Adsorption for ORNL 50 wt \% Beads

SrTreat ${ }^{\circledR}$, in contrast, showed a strong matrix effect for plutonium for some reason. It's DF for plutonium for actual waste never exceeded 2.75 in ten days. See Figure 19. This is a major contrast to its excellent plutonium performance in spiked simulant. Internal hydrolysis adsorbent (not plotted) shows the same effect, plutonium DF not exceeding 3.7 in that case. Strontium 
behavior for SrTreat ${ }^{\circledR}$ and also for internal hydrolysis granules was relatively comparable across the solutions as shown in Figure 18.

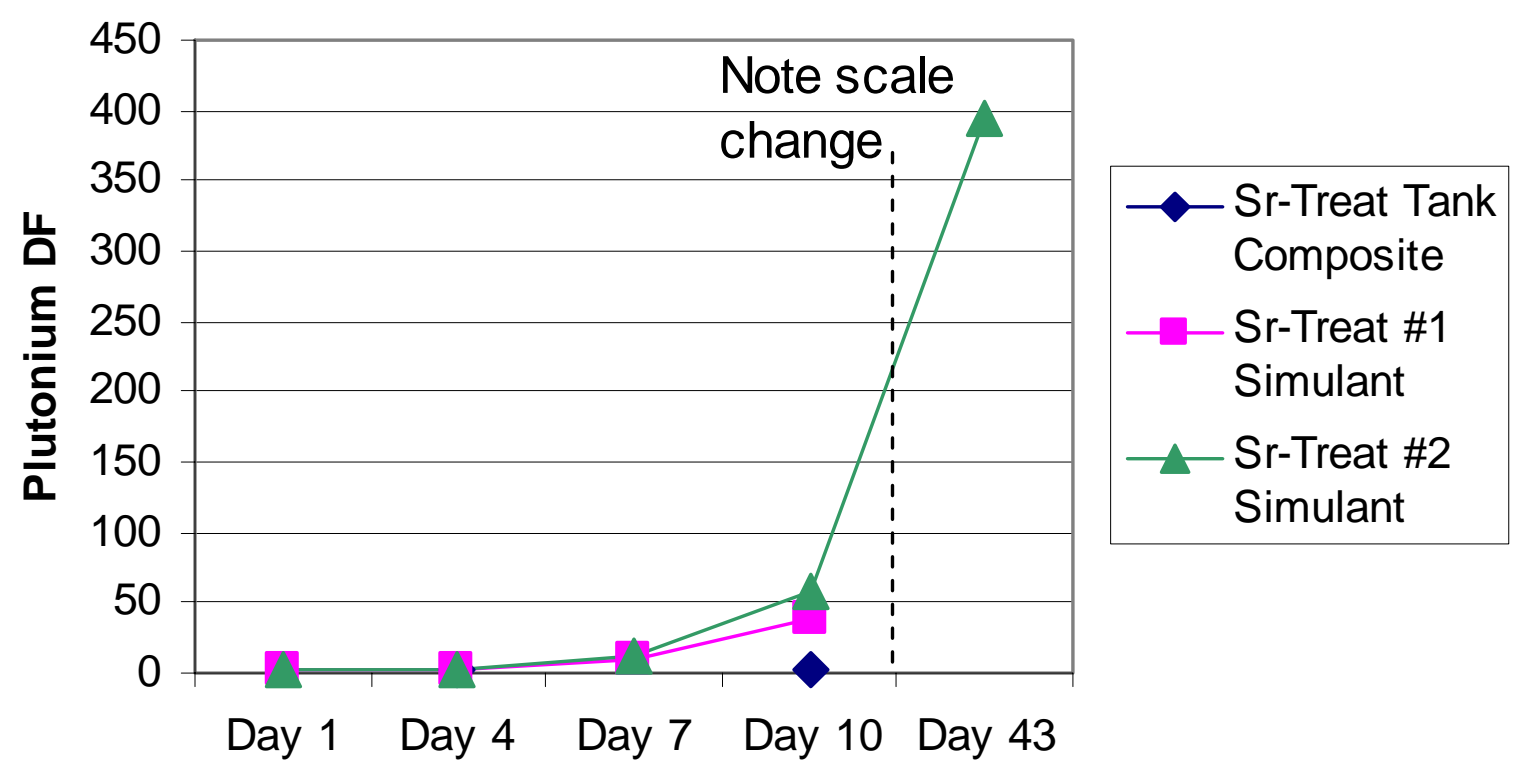

Figure 19. Comparison of Simulant vs. Actual Tank Composite Pu Adsorption for SrTreat $^{\circledR}$

\subsection{Flowsheet and DWPF Impacts of the Use of Engineered MST}

A preliminary evaluation of the impacts of engineered MST on glass production at DWPF found minor impacts on the annual canister production. ${ }^{58}$ There was little impact on canister count because titanium level was not limiting in the glass. The ORNL $50 \mathrm{wt} \% \mathrm{MST}$ beads had a practical operating window with Frit 202. Internal hydrolysis material made from Porocel ${ }^{\circledR}$ Dynocel alumina had no operating window with Frit 202 because of the high alumina loading. That material was found to be practical if Frit 433 was used.

The evaluation used a best estimate plutonium loading level of $0.14 \mathrm{wt} \%$ for the active adsorbent in the engineered materials. Since high phase ratio work has already shown that the practical loading level is much higher further flowsheet analysis will need repeated after better estimates of loading are available.

\subsection{Cost Evaluation of Engineered MST Materials}

At this time the cost of adsorbent materials has been estimated. Cost for deployment at this time is assumed to be that of deploying a small ion exchange column at SRS. The cost of equipment and startup for that deployment has been estimated separately. ${ }^{59}$

The inventor of the ORNL internal gelation process estimated the cost of engineered adsorbents in $2000 .^{60}$ The estimate did not include very expensive inorganic powders, so the $\$ 100 / \mathrm{lb}$ estimated product cost must be increased by the cost of MST for the current estimate. MST 
solids are roughly $\$ 150 / \mathrm{lb}$. Since $1 \mathrm{lb}$ of MST would yield $2 \mathrm{lb}$ of product (50 wt $\%$ loading) the cost per lb would be $(150+100) / 2$ or about $\$ 125 / \mathrm{lb}$.

Internal hydrolysis material is estimated to be the same cost as MST on a MST-only basis. This is because the same chemicals are used and the process is slightly simpler than that used to manufacture MST powder. The cost of substrate is minimal ( $\$ 1 / 1 \mathrm{~b}$ for Porocel ${ }^{\circledR}$ Dynocel alumina). One $\mathrm{lb}$ of MST contained in a total of $8 \mathrm{lb}$ of product (12.5 wt \% loading) would therefore cost about $\$ 150$. Since so much of the weight here is non-adsorbing substrate this option would also require increased shipping costs estimated to be an additional $10 \%$.

Fortum Engineering, Inc. provided a budgetary estimate of $\$ 400 / 1 \mathrm{~b}$ for SrTreat ${ }^{\circledR}$.

\subsection{Quality Assurance}

This work used the following task plan.

C. A. Nash, W. R. Wilmarth, and D. T. Hobbs, "Task Technical and Quality Assurance

Plan for Engineered Monosodium Titanate (MST) for Accelerated Nuclear Waste

Cleanup", WSRC-TR-2003-00372, revision 0, August 18, 2003.

Notebook WSRC-NB-2003-00159 (K. Adu-Wusu) contained the experimental data obtained from this testing.

\subsection{CONCLUSIONS}

This work demonstrates that engineered forms of MST with good Sr/actinide removal performance can be prepared. These materials also meet the other specifications for an engineered material. The work succeeded in manufacturing 10 engineered forms of MST. SRNL tested samples in both spiked simulant and actual waste supernate to provide performance data for the adsorbates plutonium, strontium, and neptunium.

The better performing engineered MST materials included that produced by ORNL internal gelation, the internal hydrolysis techniques, and the commercially available SrTreat ${ }^{\circledR}$. Spiked simulant plutonium and strontium data for ORNL $50 \mathrm{wt} \%$ beads compared well with those from actual tank composite supernate. The internal hydrolysis technique suffers from inability to load porous material more than about $13 \mathrm{wt} \% \mathrm{MST}$, but the adsorbent created demonstrates performance that is at least as good as that of MST powder. SrTreat ${ }^{\circledR}$ has good adsorption capacities for strontium and plutonium, but poorer removal kinetics than other materials. There was also a negative matrix effect for its plutonium removal from the tank composite sample that was used.

Testing showed that engineered materials produced by a diversity of cementation techniques as well as those produced by UOP, Inc. and Clemson using zirconium-based binders were relatively poor performers. They should not be considered for further development. 
Cements containing MST had chemical stability problems including bleed of phosphate. It is strongly recommended that other forms of hydroxyapatite or other phosphate-containing adsorbents be tested for this problem before they are considered further.

The work was successful in meeting the goals that were proposed, and in addition new information on the isotherm of MST was obtained. Physical, chemical and batch contact testing allowed elimination of many of the methods, especially engineering with various cement binders. Additional batch contact work at a phase ratio ten times higher than normal showed that the adsorbent isotherm for plutonium appears to be linear to a loading of $0.25 \mathrm{wt} \%$ plutonium. This indicates that MST will load to levels much higher than $0.25 \mathrm{wt} \%$ plutonium before it comes to equilibrium with typical feed levels of soluble plutonium.

\subsection{FUTURE WORK}

The work indicates several major avenues for future investigations of engineered MST and its adsorption properties.

- Column work is needed to determine kinetics and breakthrough characteristics of engineered adsorbents. Column work should use more than $10^{4}$ bed volumes of feed to obtain good breakthrough data.

- The MST isotherm at feed levels of plutonium needs to be examined to estimate capacity and adsorbent bed lifetime. Batch phase ratios exceeding $10^{6} \mathrm{~mL} / \mathrm{g}$ are recommended.

- The risk assessment indicated the need for testing to address material transport, bed deposition and removal, and potential for the material to solidify in the waste or in sludge mixtures.

- Scale-up of material production needs work. ORNL has reported some initial work concerning their internal gelation process, but that process is relatively equipmentintensive. Internal hydrolysis processing appears easy on the lab scale. Scaling up production needs demonstration.

- Residual carbon and nitrogen in materials made by the ORNL internal gelation process need to be quantified.

\subsection{ACKNOWLEDGEMENTS}

The authors would like to acknowledge the many staff and companies who provided materials and facility operations without which this work would not have been possible. The authors thank Jack Collins and Rodney Hunt of the ORNL, Bill Schwerin and Simon Hobbs of UOP, Inc., and Jim Congdon and Clemson/CETL for their timely production of engineered MST beads. We also thank the Porocel Company, the St. Gobain-Norpro company, and Morgan Thermal Ceramics for providing samples of alumina and firebrick substrates sufficient for our creation of internal hydrolysis samples. We thank Esko Tusa and Fortum Engineering for the sample of commercially available SrTreat $^{\circledR}$. We thank Stryker company and also the HiMed company for 
samples of calcium phosphate cements. We thank Chris Langton for provision of the Ceramicrete $^{\mathrm{TM}}$ powder. We thank John Pariez and Carol Jantzen for use of the high temperature calcining oven. We also thank Mona Blume and Lin Thacker of SRNL for performing the strontium and actinide removal performance testing as well as David DiPrete and Ceci DiPrete of SRNL for the radiochemical measurements. We thank Gavin Winship for his leadership in providing a risk assessment for the process using engineered MST and for the report. Finally we thank David Peeler, Tommy Edwards and Connie Herman of the SRNL for performing the engineering evaluation of impacts of the use of optimized MST on DWPF operations.

\subsection{REFERENCES}

\footnotetext{
1 Walker, D. D., and M. A. Schmitz, Technical Data Summary - In-Tank Processing of Soluble High Level Waste, Report DPSTD-84-103, Savannah River Plant, May 1984.

2 Nash, C. A., Hobbs, D. T., and Buck, E. C., Engineered Monosodium Titanate (MST) for Accelerated Nuclear Waste Cleanup, WSRC-SRTC-PR-03-021-04, Savannah River Site, Aiken, SC (February 2003).

${ }^{3}$ Hobbs, D. T., "Recommended Activities for the Development of an Engineered Material for Strontium and Actinide Removal from SRS Alkaline High-Level Waste Solutions”, SRT-LWP-2001-00105, June 12, 2001.
}

${ }^{4}$ Nash, C. A., D. T. Hobbs, and G. G. Wicks, Creativity Committee SWAT Team Meeting, SRT-LWP-2003-00086, September 12, 2003.

5 Nash, C. A., D. T. Hobbs and S. D. Fink, "Selection of Preferred Synthesis Options for Engineering Monosodium Titanate”, WSRC-RP-2003-1059, Savannah River Site, Aiken, SC 29808 (2004).

${ }^{6}$ Herman, C., Edwards, T., and Peeler, D., The Impact of Alternative Sorbents as Compared to Monosodium Titanate on the Defense Waste Processing Facility, WSRC-TR-2004-00200, Savannah River Site, Aiken, SC 29808 (2004).

${ }^{7}$ Nash, C. A., and G. C. Winship, "Engineered Monosodium Titanate (MST) Risk Assessment Report”, WSRC-RP2004-00417, River Site, Aiken, SC 29808, May 26, 2004

8 Barnes, M. J., Fondeur, F. F., Hobbs, D. T., and Fink, S. D., Monosodium Titanate Multi-Strike Testing, WSRCTR-2004-00145, Savannah River Site, Aiken, SC 29808, April 29, 2004.

${ }^{9}$ Lynch, R. W., Dosch, R. G., Kenna, B. T., Johnstone, J. K., and Nowak, E. J., International Atomic Energy Agency Report. SM-207/75, Vienna (1995).

${ }^{10}$ Schulz, W. W., Koenst, J. W., and Talant, D. R., “ACS Symp. Series 117, Active Separations.” American Chemical Society, Washington D.C., pp 17, (1980).

${ }^{11}$ Heitner-Wirguin, C., and Albu-Yaron, A., J. Inorg. Nucl. Chem. 28, p 2379 (1966).

${ }^{12}$ Lehto, J., Heinonen, O. J., and Miettinen, J. K., Radiochem. Radioanal. Let. 46, p 381 (1981).

${ }^{13}$ Lehto, J., Harjula, R., and Girard, A., J. Chem. Soc., Dalton Trans. 1, p 101 (1989).

14 Hobbs, D. T., Nyman, M. D., and Clearfield, A., Tailoring Inorganic Sorbents for SRS Strontium and Actinide Separations: Optimized Monosodium Titanate and Pharmacosiderite Phase 1 Final Report, WSRC-TR-200400322, Savannah River Site, Aiken, SC 29808, July 2004. 
${ }^{15}$ Hobbs, D. T., and Walker, D. D., Plutonium and Uranium Adsorption on Monosodium Titanate, WSRC-RP-9293, Savannah River Site, Aiken, SC 29808, August 13, 1992.

${ }^{16}$ Hobbs, D. T., Bronikowski, M., Edwards, T., and Pulmano, R., Final Report on Phase III Testing of Monosodium Titanate Adsorption Kinetics, WSRC-TR-99-00134, Savannah River Site, Aiken, SC 29808, rev. 0, May 28, 1999.

${ }^{17}$ Chandler, M. C., Nuclear Criticality Safety Bounding Analysis for the In-Tank Precipitation (ITP) Process, WSRC-TR-93-00171, rev. 0, Savannah River Site, Aiken, SC 29808 (March 1993).

18 SRS High Level Waste Division, Procurement Specification for Monosodium Titanate, rev. 2, Z-SPP-H-0001, Savannah River Site, Aiken, SC 29808.

19 Lambert, D., SRNL Analysis of Optima Monosodium Titanate (MST), SRT-LWP-2002-00091, rev. 1, Savannah River Site, Aiken, SC 29808 (2002).

${ }^{20}$ Poirier, M., F. Fondeur, D. Lambert, D. Hobbs, and S. Fink, Particle Size of Simulated SRS Sludge, Actual SRS Sludge, and Monosodium Titanate, WSRC-TR-2003-00221, Savannah River Site, Aiken, SC 29808 (2003).

${ }^{21}$ Dosch, R., The Use of Titanates in Decontamination of Defense Waste, SAND78-0710, Sandia National Laboratory (1978).

${ }^{22}$ Clearfield, A., Inorganic Ion Exchange Materials, CRC Press, Boca Raton, Florida (1982).

${ }^{23}$ R. Caletka and M. Tympl, "Uptake of Inorganic Acids on Hydrogels of Tetravalent Hydroxides and Its Application for the Preparation of Some Inorganic Sorbents," Journal of Radioanalytical Chemistry 30 pp. 155-172 (1976)

${ }^{24}$ Nash, C. A., Pelletized Monosodium Titanate (MST), FBO Daily Issue of August 06, 2003, Solicitation Number CAN-100MST.

25. Not used.

${ }^{26}$ Bruggens, F. W., A. J. Noothout, M. E. A. Hermans, J. B. W. Knaji, and O. Votocek, "A U(VI)-Process for Microsphere Production," Proc. Symp. Sol-Gel Processes and Reactor Fuel Cycles, Gatlinburg, Tennessee, May 47, 1970, CONF-700502, U. S. Atomic Energy Commission (1970).

${ }^{27}$ Baran, V., R. Caletka, M. Tympl, and V. Urbanek, "Application of the Sol-Gel Method for the Preparation of Some Inorganic Ion-Exchangers in Spherical Form," Journal of Radiochemistry 24 pp. 353-359 (1975)

${ }^{28}$ Haas, P. A., J. M. Begovich, A. D. Ryon, and J. S. Vavruska, "Chemical Flowsheet Conditions for Preparing Urania Spheres by Internal Gelation,” Ind. Eng. Chem. Prod. Res. Dev., 19: 3, (1980).

${ }^{29}$ Collins, J. L., B. Z. Egan, and K. K. Anderson, Development and Testing of Spheroidal Inorganic Sorbents, published in the proceedings of the Efficient Separations and Processing Crosscutting Program 1997 Technical Exchange Meeting, January 28-30, 1997 Gaithersburg, Maryland.

${ }^{30}$ Collins, J. L., (to Lockheed Martin Energy Research Corporation, Oak Ridge, TN), U.S. Patent No. 5,821,186, Method of Preparing Hydrous Titanium Oxide Gels and Spherules (issued 10/13/1998).

${ }^{31}$ Wilson, A. D., and J. W. Nicholson, Acid-Base Cements, p. 222 and following, Cambridge University Press, New York (1993). 
${ }^{32}$ Wagh, A., S. Jeong, and D. Singh, "Mercury Stabilization in Chemically Bonded Phosphate Cements", Environmental Issues and Waste Management Technologies in the Ceramic and Nuclear Industries III, Ceramic Transactions Vol. 87, pp. 63-73, 1998.

${ }^{33}$ Wagh, A., and S. Jeong, "Chemically Bonded Phosphate Ceramics", Journal of the American Ceramic Society, 86:11 pp. 1838-1844 (2003).

${ }^{34}$ Langton, C., Ceramicrete Stabilization of CST Resin: Salt Waste Alternative Phase III Feasibility Study (U), WSRC-TR-98-00338, Savannah River Site, Aiken, SC 29808 (1998).

${ }^{35}$ Finch, T., and J. Sharp, "Chemical Reactions between Magnesia and Aluminum Orthophosphate to Form Magnesia-Phosphate Cements", Journal of Material Science, 24, pp. 4379-4386 (1989)

${ }^{36}$ Rodriguez-Lorenzo, L., and M. Vallet-Regi, "Controlled Crystallization of Calcium Phosphate Apatites", Chemistry of Materials, 12 pp. 2460-2465 (2000).

${ }^{37}$ Khairoun, I., M. Boltong, F. Driessens, and J. Planell, "Some Factors Controlling the Injectability of Calcium Phosphate Bone Cements”, Journal of Materials Science: Materials in Medicine 9 pp. 425-428 (1998).

${ }^{38}$ Brown, P., N. Hocker, and S. Hoyle, "Variations in Solution Chemistry during the Low-Temperature Formation of Hydroxyapatite", Journal of the American Ceramic Society, 74:8 pp. 1848-1854 (1991).

${ }^{39}$ Wester, D., P. Berry, B. Cook, J. Deschane, B. Rapko, D. Baldwin, K. Carson, L. Darnell, T. Levitskaia, and C. Soderquist, Ion-Exchange Research in Support of Modular Treatment of Savannah River Site Tank Wastes, PNNL45344, Pacific Northwest National Laboratory, Richland, WA, (2003)

${ }^{40}$ Bermudez, O., M. Boltong, F. Driessens, and J. Planell, "Development of Some Calcium Phosphate Cements from Combinations of a-TCP, MCPM and CaO”, Journal of Materials Science: Materials in Medicine 5 pp. 160-163 (1994).

${ }^{41}$ Driessens, F., Bermudez, O., M. Boltong, J. Planell, M. Ginebra, and E. Fernandez, "Effective Formulations for the Preparation of Calcium Phosphate Bone Cements", Journal of Materials Science: Materials in Medicine 5 pp. 164-170 (1994).

${ }^{42}$ Wilmarth, W., S. Fink, D. Hobbs, and M. Hay, Characterization and Dissolution Studies of Samples from the 242-16H Evaporator Gravity Drain Line, WSRC-TR-97-0326, Savannah River Site, Aiken, SC 29808 (1997).

${ }^{43}$ Wilmarth, W., M. Thompson, C. Martino, V. Dukes, J. Mills, C. Boley, and B. Lewis, "Nitric Acid Cleaning of a Sodalite-Sodium Diuranate Scale in High Level Waste Evaporators", Separation Science and Technology, 38 p. 3249 (2003)

${ }^{44}$ Davidovits, J., U.S. Patent 4,349,386 (September 14, 1982).

${ }^{45}$ Davidovits, J., U.S. Patent 4,472,199 (September 18, 1984).

${ }^{46}$ Dosch, R., The Use of Titanates in Decontamination of Defense Waste, SAND78-0710, Sandia National Laboratory (1978).

${ }^{47}$ Bray, L., and F. Hara, Use of Titanium-Treated Zeolite for Plutonium, Strontium, and Cesium Removal from West Valley Alkaline Wastes and Sludge Wash Waters, PNL-SA-19697, Pacific Northwest National Laboratory, Richland, WA 99352, 1991.

48 Bray, L., and L. Burger, (to Battelle Memorial Institute) U.S. Patent 5,298,166 (March 29, 1994). 
${ }^{49}$ Dosch, R., Final Report on the Application of Titanates, Niobates, and Tantalates to Neutralized Defense Waste Decontamination - Materials Properties, Physical Forms, and Regeneration Techniques, SAND80-1212, Sandia National Laboratory (1980).

50 Adu-Wusu, K., RPP Ion Exchange, Laboratory notebook WSRC-NB-2003-00159, pp.43, Savannah River Site, Aiken, SC 29808, opened July 14, 2003.

${ }^{51}$ Hsu, C., "The Preparation of Biphasic Porous Calcium Phosphate by the Mixture of $\mathrm{Ca}(\mathrm{H} 2 \mathrm{PO} 4) 2 * \mathrm{H} 2 \mathrm{O}$ and CaCO3", Materials Chemistry and Physics, 80, pp.409-420, (2003)

${ }^{52}$ Bermudez, O., Boltong, M., Driessens, F., Planell, J., "Development of Some Calcium Phosphate Cements from Combinations of a-TCP, MCPM, and CaO", Journal of Materials Science, Materials in Medicine, vol. 5, pp.160163, (1994)

${ }^{53}$ Enz. G., K. Heung, and G. Wicks, Preliminary Test of a Sol-Gel Method for Preparing a New Metal HydrideGlass Composite, SRL-HTS-0227, Savannah River Site, Aiken, SC 29808.

${ }^{54}$ Buck, E. C., Arey, B. W., McNamara, B. K., and J. S. Young, Electron Microscopy Characterization of Engineered Monosodium Titanate, PNNL-14814, Pacific Northwest National Laboratory, Richland, WA (2004).

55 Dietz, N. L., Fortner, J. A., Dai, Z., Bradley, J. P., Duff, M. C., Hobbs, D. T., and Fink, S. D., Transmission Electron Microscopy Analyses of Strontium and Actinide-Bearing Monosodium and Permanganate Treatment Solids, WSRC-TR-2002-00363, Savannah River Site, Aiken, SC 29808 (2002).

${ }^{56}$ Hobbs, D., M. Blume, and H. Thacker, Phase V Simulant Testing of Monosodium Titanate Adsorption Kinetics, WSRC-TR-2000-00142, Savannah River Site, Aiken, SC 29808 (2000).

${ }^{57}$ Hobbs, D., and S. Fleishman, Fissile Solubility and Monosodium Titanate Loading Tests, WSRC-RP-92-1273, Savannah River Site, Aiken, SC 29808 (1993).

${ }^{58}$ Herman, C., T. Edwards, and D. Peeler, The Impact of Alternative Sorbents as Compared to Monosodium Titanate on the Defense Waste Processing Facility, WSRC-TR-2004-00200, Savannah River Site, Aiken, SC 29808 (2004).

59 Walker, Jr., J., P. Taylor, R. Spence, C. Slater, D. Walker, D. Bickford, S. Lee, S. Aleman, and L. Hamm, SmallColumn Ion Exchange Alternative to Remove Cs-137 from Low Curie Salt Waste: Summary of Phase I, ORNL/TM2003/287, Oak Ridge National Laboratory, Oak Ridge, TN, 37831 (2004).

${ }^{60}$ Collins, J., and J. Watson, Economic Evaluation for the Production of Sorbents and Catalysts Derived from Hydrous Titanium Oxide Microspheres Prepared by the HMTA Internal Gelation Process, ORNL/TM-1999/212, Oak Ridge National Laboratory, Knoxville, TN (2000). 
WSRC-TR-2004-00286, Revision 0

\section{APPENDIX A. SPECIFICATION SHEETS}

Page 39 of 56 
WSRC-TR-2004-00286, Revision 0

\section{Fortum}

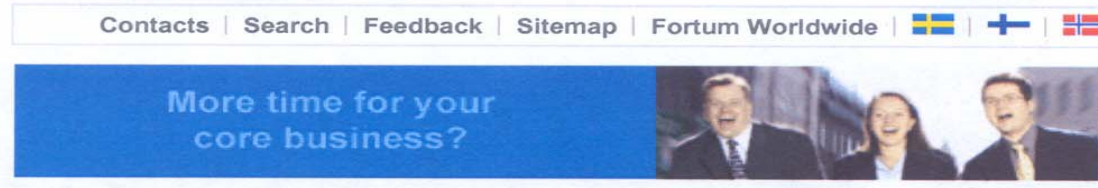

Business customers
About Fortum

Home customers

Oil | Electricity | Gas | Heat and Cooling | Services | Operations \& Maintenance |

- Services

- Hydropower

- Nuclear services

- Nuclear safety

- APROS - Advanced

process simulator

- Mechanical engineering

- Plant modernization

- Nuclear Waste

Management

NURES - Nuclide Removal

System

- Selion - Selective Ion

Exchange Technologies

- How is it possible?

- Products and Services

- CsTreat

- SrTreat

- JAERI column test data

- Effect on common cations

- Hanford DSSF-5 and NCAV simulants

- Kd of $\mathrm{Sr}-85$ vs $\mathrm{pH}$

- NURES operation at Murmansk

- Reprocessing waste liquid simulant

- CoTreat

- Publications

- References

- Contact

- Support of Plant Operation

- Oil, gas and chemicals engineering

- Refining technologies

- Shipping

- Terminal services
Business Customers / Services / Nuclear services / Nuclear Waste Management / Selion Selective Ion Exchange Technologies / Products and Services / SrTreat

\section{SrTreat}

\section{What is SrTreat?}

SrTreat is a titanium oxide based ion exchanger highly selective for strontium. It removes very efficiently strontium from both concentrated and dilute waste solutions. The optimum $\mathrm{pH}$ range fc its use is ten and above.

High sodium concentrations do not practically interfere with strontium exchange but calcium ions have a rather detrimental effect on strontium removal at higher concentrations. SrTreat can poss be used also in the separation of other waste nuclides, especially $\mathrm{Pu}$ and $\mathrm{Zn}$.

SrTreat is registered trademark of Fortum Nuclear Services Ltd.

\section{SrTreat for Strontium removal}

\section{Operating Environment}

- $\mathrm{pH}$ above 10

- Max. temperature $+300{ }^{\circ} \mathrm{C}$

- Suitable for both column and bed operations

- Service flow rate typically 10 - $20 \mathrm{BV} / \mathrm{h}$

- Dirt, oil and grease should be prefiltere

For further information, please contact:

Mr. Esko Tusa, esko.tusa@fortum.com

Fortum Nuclear Services Ltd

POB 10

00048 Fortum

Finland

Tel +358104511

Fax +358104533355 
WSRC-TR-2004-00286, Revision 0

\section{. \\ Fortum}

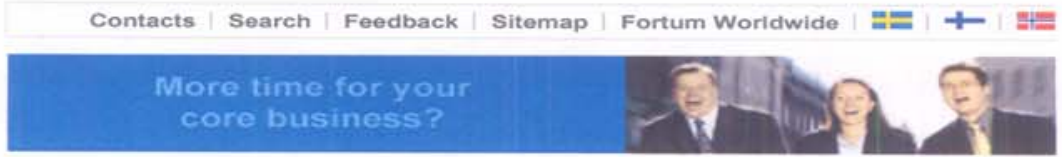

Business customers

About Fortum

Oil | Electricity | Gas | Heat and Cooling | Services | Operations \& Maintenance |

- Services

- Hydropower

- Nuclear services

- Nuclear safety

- APROS - Advanced

process simulator

- Mechanical engineering

- Plant modernization

- Nuclear Waste

Management

- NURES - Nuclide Removal

System

- Selion - Selective Ion

Exchange Technologies

- How is it possible?

- Products and Services

- CsTreat

- SrTreat

- JAERI column test data

- Effect on common cations

- Hanford DSSF-5 and NCAV simulants

- Kd of $\mathrm{Sr}-85 \mathrm{vs} \mathrm{pH}$

- NURES operation at

Murmansk - Reprocessing waste liquid -
simulant

- CoTreat

- Publications

- References

- Contact

- Support of Plant Operation

- Oil, gas and chemicals

engineering

- Refining technologies

- Shipping

- Terminal services
Business Customers / Services / Nuclear services / Nuclear Waste Management / Selion -

Selective Ion Exchange Technologies / Products and Services / SrTreat / Effect on common cati،

\section{Effect on common cations}

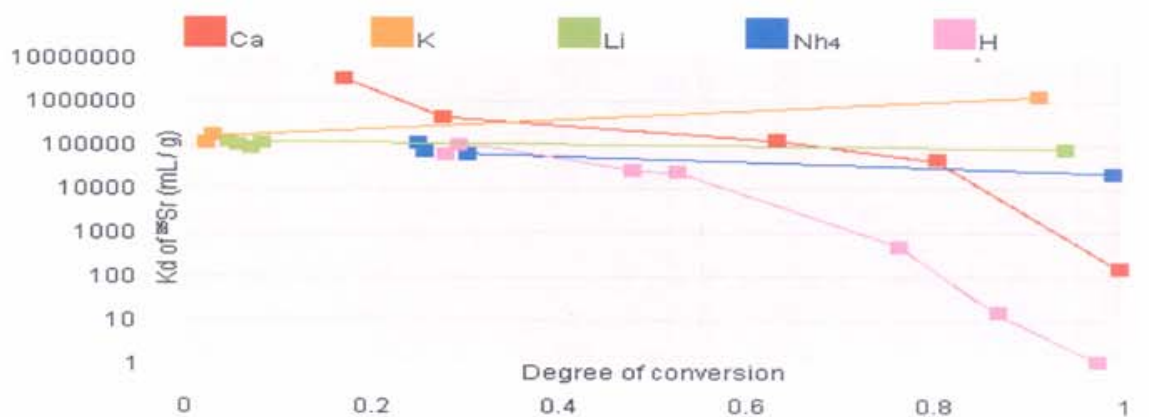

$\Theta$ Print $\square$ Send this page to a fr 
WSRC-TR-2004-00286, Revision 0

\section{Fortum}

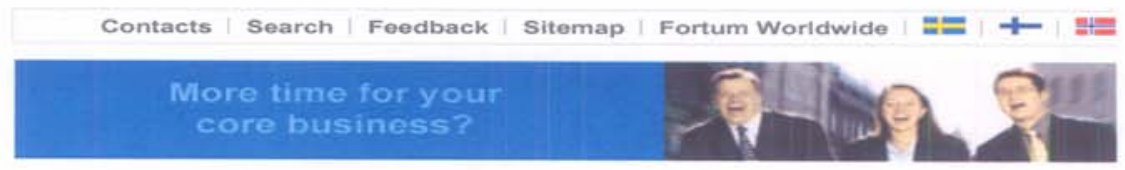

Home customers

Business customers

About Fortum

Oil I Electricity I Gas I Heat and Cooling | Services I Operations \& Maintenance |

- Services

- Hydropower

- Nuclear services

- Nuclear safety

- APROS - Advanced

process simulator

- Mechanical engineering

- Plant modernization

- Nuclear Waste

Management

NURES - Nuclide Removal

System

- Selion - Selective Ion

Exchange Technologies

- How is it possible?

- Products and Services

- CsTreat

- SrTreat

- JAERI column test data

- Effect on common cations

- Hanford DSSF-5 and NCAV simulants

- Kd of Sr-85 vs pH

- NURES operation at

Murmansk

- Reprocessing waste liquid simulant

- CoTreat

- Publications

- References

- Contact

- Support of Plant Operation

- Oil, gas and chemicals engineering

- Refining technologies

- Shipping

- Terminal services
Business Customers / Services / Nuclear services / Nuclear Waste Management / Selion Selective Ion Exchange Technologies / Products and Services / SrTreat / Hanford DSSF-5 and NCAV simulants

\section{Hanford DSSF-5 and NCAV simulants}

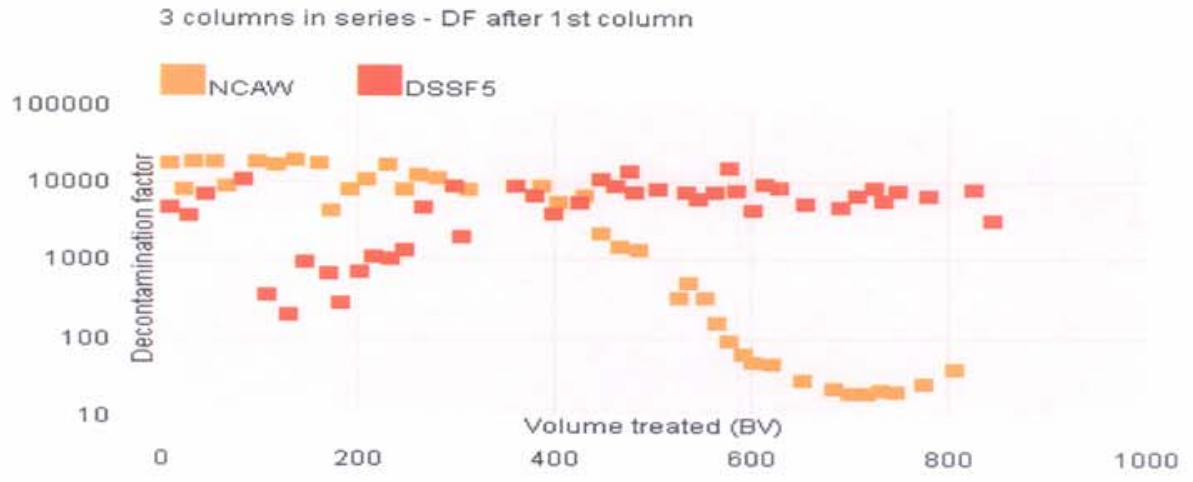

3 columns in series - DF after 3 rd column

100000 NCAW $\square$ ma DSSF

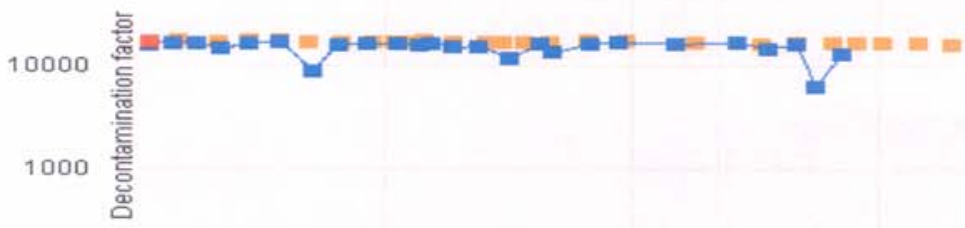

100

Volume treated (BV)

$200 \quad 300$

400

Print $\square$ Send this page to a fr 
WSRC-TR-2004-00286, Revision 0

\section{(O) Fortum}

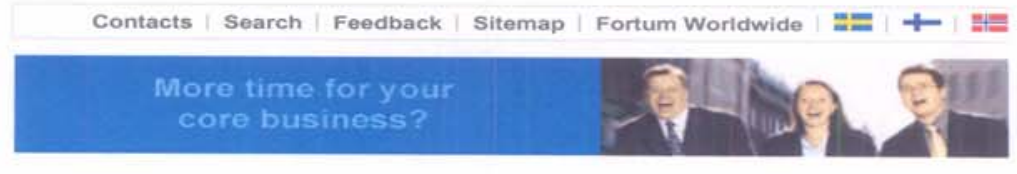

Business customers
About Fortum

Home customers

Oil | Electricity | Gas I Heat and Cooling | Services | Operations \& Maintenance |

- Services

- Hydropower

- Nuclear services

- Nuclear safety

- APROS - Advanced

process simulator

- Mechanical engineering

- Plant modernization

- Nuclear Waste

Management

- NURES - Nuclide Removal

System

- Selion - Selective Ion

Exchange Technologies

- How is it possible?

- Products and Services

- CsTreat

- SrTreat

- JAERI column test data

- Effect on common cations

- Hanford DSSF-5 and NCAV simulants

- Kd of $\mathrm{Sr}$-85 vs pH

- NURES operation at

Murmansk - Reprocessing waste liquid.
simulant

- CoTreat

- Publications

- References

- Contact

- Support of Plant Operation

- Oil, gas and chemicals engineering

- Refining technologies

- Shipping

- Terminal services
Business Customers / Services / Nuclear services / Nuclear Waste Management / Selion Selective Ion Exchange Technologies / Products and Services / SrTreat / Kd of Sr-85 vs pH

\section{Kd of $\mathrm{Sr}-85$ vs pH}

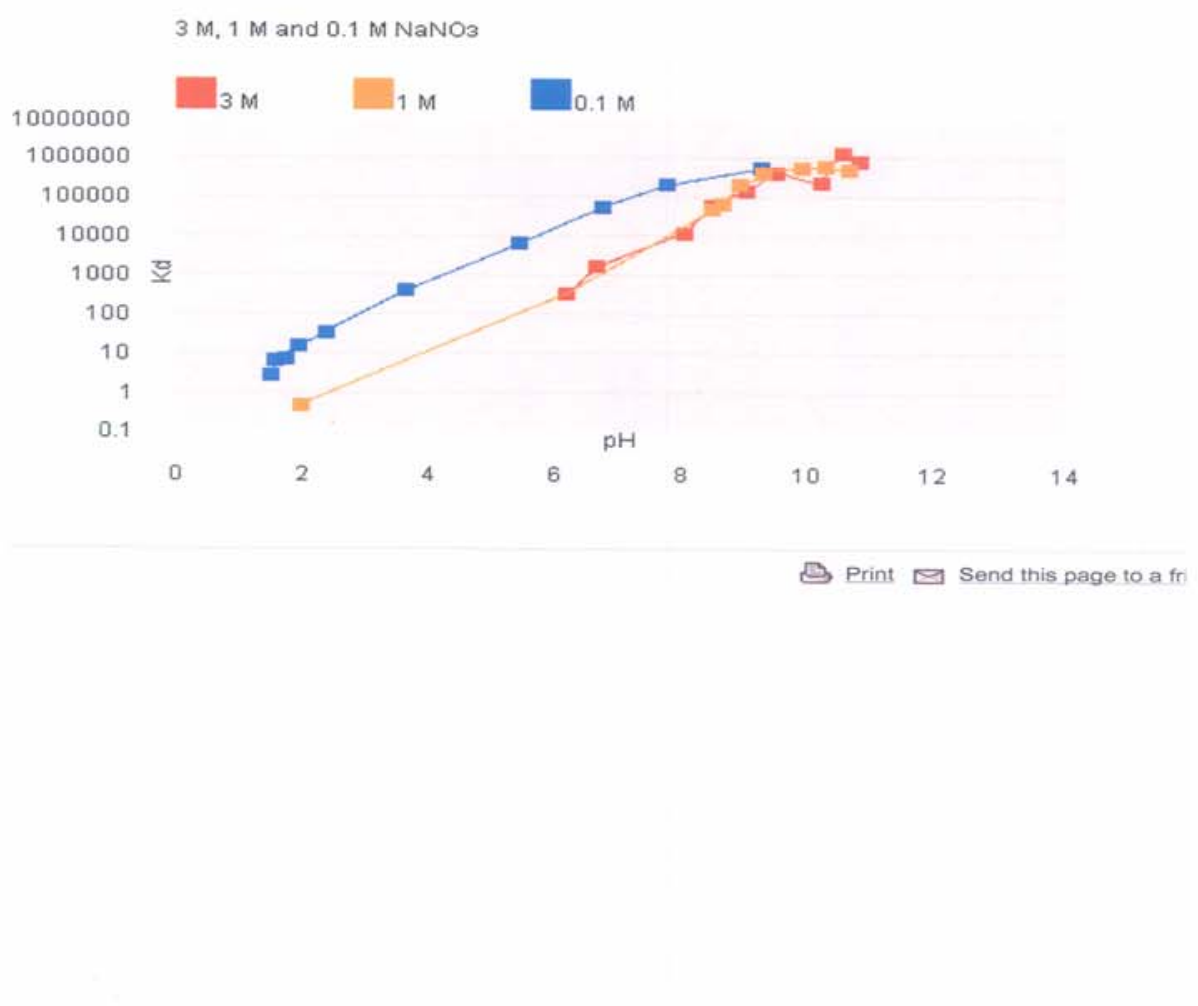


WSRC-TR-2004-00286, Revision 0

\section{Q \\ Fortum}

Home customers

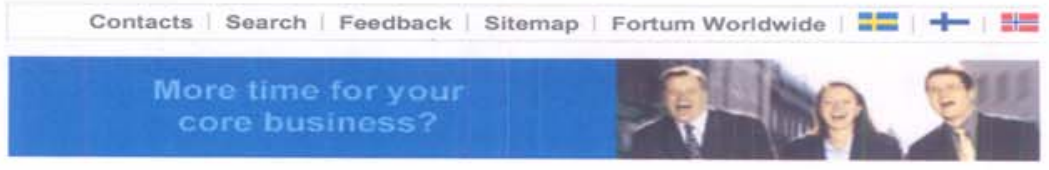

Business customers

About Fortum

Oil I Electricity I Gas I Heat and Cooling I Services I Operations \& Maintenance I

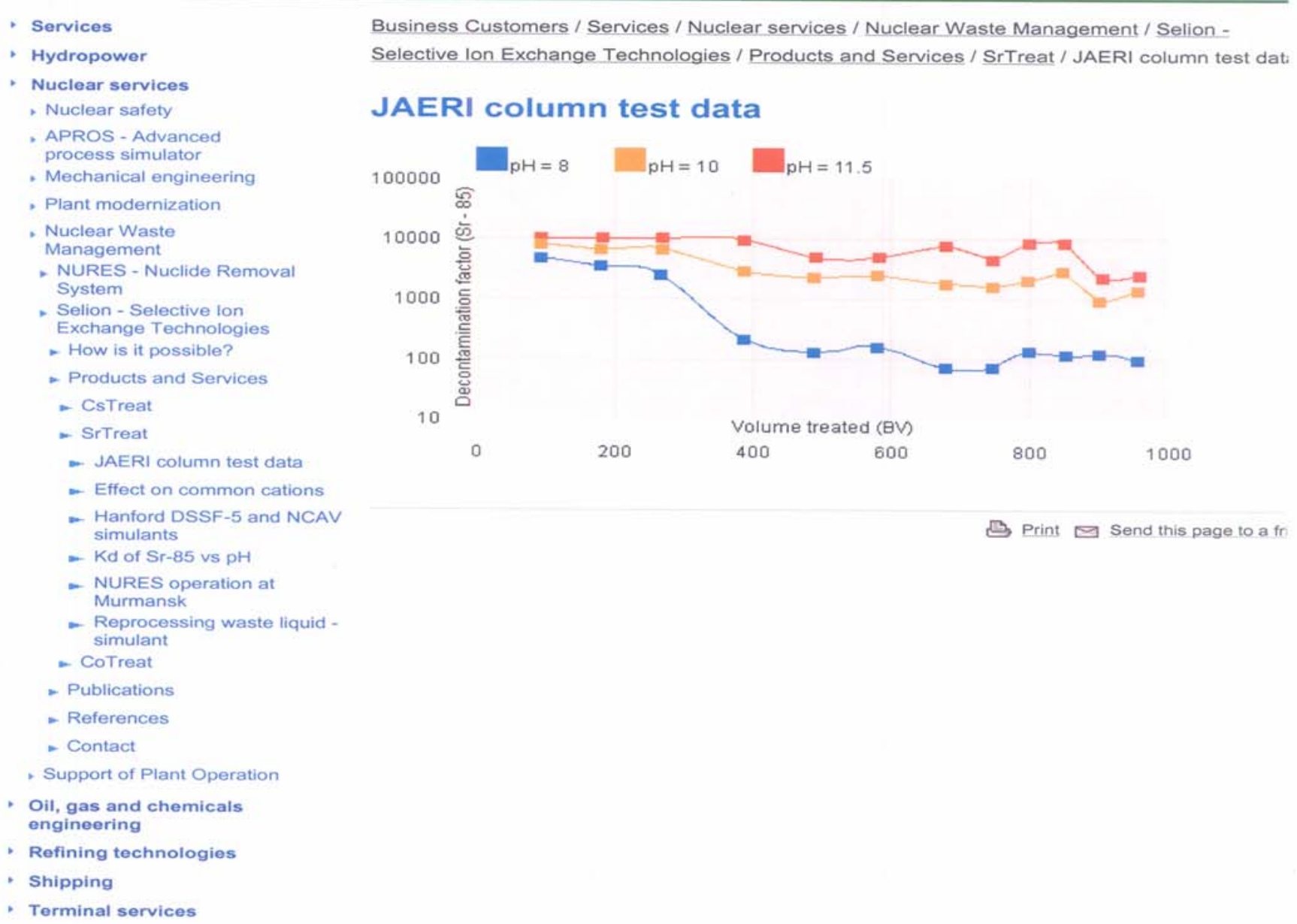




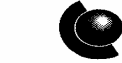 \\ Fortum}

Handled by:

Eveliina Mettänen

Transport firm:

UPS-Courier

Consignee:

WESTINGHOUSE SAVANNAH RIVER CO.

Bldg. 773-42A, Rm 182

Aiken, SC 29808

USA

Export carriage

From

Vantaa, Finland

Final destination
PROFORMA INVOICE NO ENJ280703

Date

28.7.2003

Buyer's Reference

Seller's reference:
Contact person:

Mr. Charles Nash

tel. +803-825-2615

$\begin{array}{ll}\text { Country of origin: } & \text { Country of destination: } \\ \text { Finland } & \text { USA }\end{array}$

Terms and time of delivery:

USA

Aiken

Terms of payment:

No charge, value for customs purpose only

Mark and numbers

Number and kind of packages, description of goods

Gross weight

Volume

UPS Waybill No. 1 case

1Z 15398 V 6699945383 Sample

$0,350 \mathrm{kgs}$

Total

$0,350 \mathrm{kgs}$

This sample is for R\&D purposes only, and not for resale.

It should be handled only by qualified laboratory personel.

Specifications of goods, type, model, serial no. etc.

Quantity

Gurrency

Amount

Sample of highly selective ion exchange media for strantium removal, SrTreat

volume about $350 \mathrm{~g}$

grain size $0.30-0.85 \mathrm{~mm}$

Instructions for use, SrTreat

Material Safety Data Sheets, SrTreat

Value for customs purposes only USD 2.00

FORTUM NUCLEAR SERVICES LTD

Forwarding

Qeep

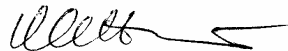

Eveliina Mettänen

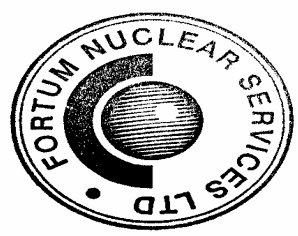

Fortum Nuclear Services Ltd

VAT No FI 1655971-4 Trade Reg. No 808.606 Domicile Espoo

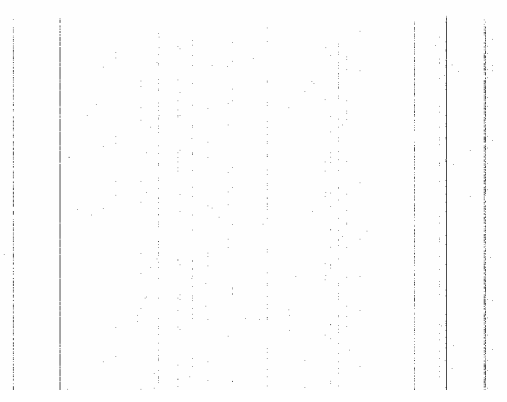

Page 45 of 56 


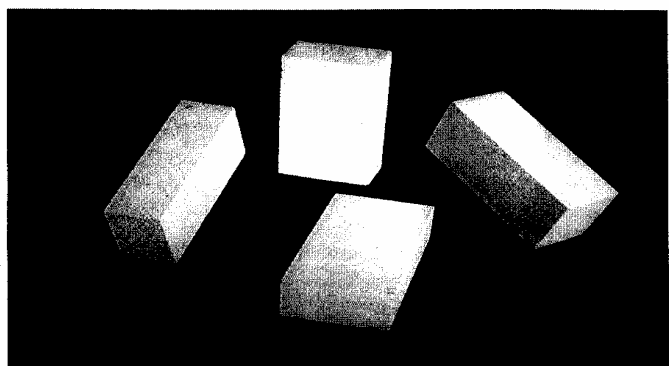

Thermal Ceramics high temperature insulating firebrick are produced with unique processes. The bond developed is a ceramic bond that is formed by high temperature firing. This produces bricks that are very stable and strong at temperatures higher than $2600^{\circ} \mathrm{F}\left(1427^{\circ} \mathrm{C}\right)$.
Features

- High temperature insulating firebrick with use limits

up to $3250^{\circ} \mathrm{F}\left(1788^{\circ} \mathrm{C}\right)$

- Excellent strength and thermal stability

- Low heat storage

- High purity

- Excellent thermal conductivity

Applications

- Atmosphere furnace

- Forge furnaces

- Ethylene furnace sidewalls

- Ceramic kilns

- High temperature back-up insulation

- Carbon baking furnaces

- High temperature kiln linings

- Removable furnace doors

Physical Characteristics

Standard sizes*

$9^{\prime \prime} \times 41 / 2 " \times 21 / 2 "$ and $9^{\prime \prime} \times 41 / 2 " \times 3 "$ $(22.5 \mathrm{~cm} \times 11.25 \mathrm{~cm} \times 6.25 \mathrm{~cm}$ and $22.5 \mathrm{~cm} \times 11.25 \mathrm{~cm} \times 7.5 \mathrm{~cm}$ )

* Special sizes available upon request. 


\section{High Temperature Insulating Firebrick}

\begin{tabular}{|c|c|c|c|c|c|c|}
\hline & & & & & Product Ir & formation \\
\hline Physical properties & TC-26 & K-26 & JM-26 & JM-28 & JM-30 & Insalcor \\
\hline $\begin{array}{l}\text { Recommended Hot Face use limit, }{ }^{\circ} \mathrm{F} \\
{ }^{\circ} \mathrm{C}\end{array}$ & $\begin{array}{l}2600 \\
(1427)\end{array}$ & $\begin{array}{l}2600 \\
(1427)\end{array}$ & 2600 & 2800 & 3000 & 3250 \\
\hline Density, nominal & & & & $(7538)$ & & \\
\hline lb/9" straight $(\mathrm{kg})$ & $2.8(1.2)$ & $2.3(1.04)$ & $2.9(1.3)$ & $3.2(1.45)$ & $3.8(1.72)$ & $4.6(2.09)$ \\
\hline pcf $\left(\mathrm{kg} / \mathrm{m}^{3}\right)$ & $48(769)$ & $40(641)$ & $50(801)$ & $55(881)$ & $65(1041)$ & $82(1314)$ \\
\hline Modulus of rupture, psi (Mpa) & $200(1.37)$ & $145(1)$ & $190(1.31)$ & $220(1.51)$ & $250(1.72)$ & $450(3.1)$ \\
\hline Cold crushing strength, psi (Mpa) & $270(1.86)$ & $245(1.7)$ & $290(2)$ & $340(2.35)$ & $440(3.03)$ & $900(6.2)$ \\
\hline Permanent linear shrinkage, $\%$, after 2 & urs & & & & & \\
\hline @ $2550^{\circ} \mathrm{F}\left(1400^{\circ} \mathrm{C}\right)$ & -0.1 & -0.1 & -0.2 & - & - & - \\
\hline (a) $2750^{\circ} \mathrm{F}\left(1510^{\circ} \mathrm{C}\right)$ & - & - & - & -0.7 & - & - \\
\hline @ $2950^{\circ} \mathrm{F}\left(1620^{\circ} \mathrm{C}\right)$ & - & - & - & - & -0.7 & - \\
\hline @ $3150^{\circ} \mathrm{F}\left(1732^{\circ} \mathrm{C}\right)$ & & - & - & - & - & +0.4 \\
\hline Deformation under hot load, \%@10 p & o> Mpa) & & & & & \\
\hline $11 / 2$ hours @ $2200^{\circ} \mathrm{F}\left(1204^{\circ} \mathrm{C}\right)$ & -0.2 & -0.2 & -0.2 & -0.1 & - & - \\
\hline $11 / 2$ hours @ $2400^{\circ} \mathrm{F}\left(1315^{\circ} \mathrm{C}\right)$ & - & - & - & - & -0.3 & - \\
\hline $11 / 2$ hours @ $2640^{\circ} \mathrm{F}\left(1448^{\circ} \mathrm{C}\right)$ & - & - & - & - & - & +0.1 \\
\hline Chemical Composition & & & & & & \\
\hline Alumina, $\mathrm{Al}_{2} \mathrm{O}_{3}$ & 47 & 48 & 60.4 & 67 & 69.9 & 77 \\
\hline Silica, $\mathrm{SiO}_{2}$ & 48.6 & 38 & 36.1 & 30.5 & 28.1 & 21.5 \\
\hline Ferric oxide, $\mathrm{Fe}_{2} \mathrm{O}_{3}$ & 0.7 & 0.4 & 0.4 & 0.3 & 0.3 & 0.4 \\
\hline Titanium oxide, $\mathrm{TiO}_{2}$ & 1.3 & 0.9 & 1.0 & 0.9 & 1.2 & 0.6 \\
\hline Calcium oxide, CaO & 0.3 & 12.3 & 0.1 & 0.3 & 0.2 & 0.1 \\
\hline Magnesium oxide, MgO & 0.1 & 0.1 & 0.2 & - & 0.1 & 0.1 \\
\hline Alkalies, as $\mathrm{Na}_{2} \mathrm{O}$ and $\mathrm{K}_{2} \mathrm{O}$ & 2.0 & 0.3 & 1.8 & 1.0 & 0.2 & 0.3 \\
\hline $\begin{array}{l}\text { Thermal Conductivity, BTU•in./hr•ft } \\
\text { Mean temperature }\end{array}$ & $m \bullet k)$ AS & 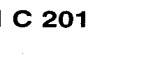 & & & & \\
\hline (9) $500^{\circ} \mathrm{F}\left(260^{\circ} \mathrm{C}\right)$ & $1.6(0.23)$ & $1.16(0.17)$ & $1.8(0.26)$ & $2.3(0.33)$ & $2.8(0.40)$ & $5.5(0.79)$ \\
\hline (a) $1000^{\circ} \mathrm{F}\left(538^{\circ} \mathrm{C}\right)$ & $1.9(0.27)$ & $1.34(0.19)$ & $2.0(0.29)$ & $2.4(0.34)$ & $2.9(0.42)$ & $5.6(0.80)$ \\
\hline (a) $1500^{\circ} \mathrm{F}\left(815^{\circ} \mathrm{C}\right)$ & $2.2(0.32)$ & $1.52(0.22)$ & $2.1(0.30)$ & $2.6(0.37)$ & $3.1(0.45)$ & $6.3(0.91)$ \\
\hline @ $2000^{\circ} \mathrm{F}\left(1093^{\circ} \mathrm{C}\right)$ & $2.6(0.37)$ & $1.74(0.25)$ & $2.3(0.33)$ & $2.7(0.39)$ & $3.3(0.47)$ & $7.6(1.09)$ \\
\hline @ $2500^{\circ} \mathrm{F}\left(1371^{\circ} \mathrm{C}\right)$ & - & - & - & - & - & $9.2(1.33)$ \\
\hline
\end{tabular}

The values given herein are typical average values obtained in accordance
with accepted test methods and are subject to normal manufacturing variations. They are supplied as a technical service and are subject to change specification purposes. Check with your Thermal Ceramics not be used for current information.

Thermal Ceramics is a trademark of The Morgan Crucible Company plc.

Marketing Communications Offices North America - Sales Offices

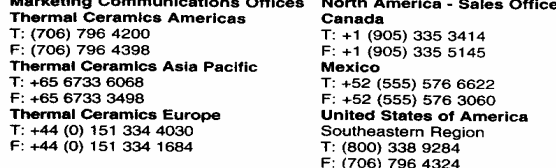

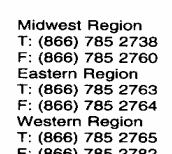

F: $(866) 7852782$

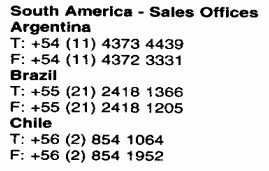

Website: www.thermalceramics.com

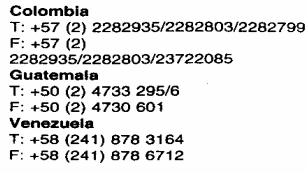

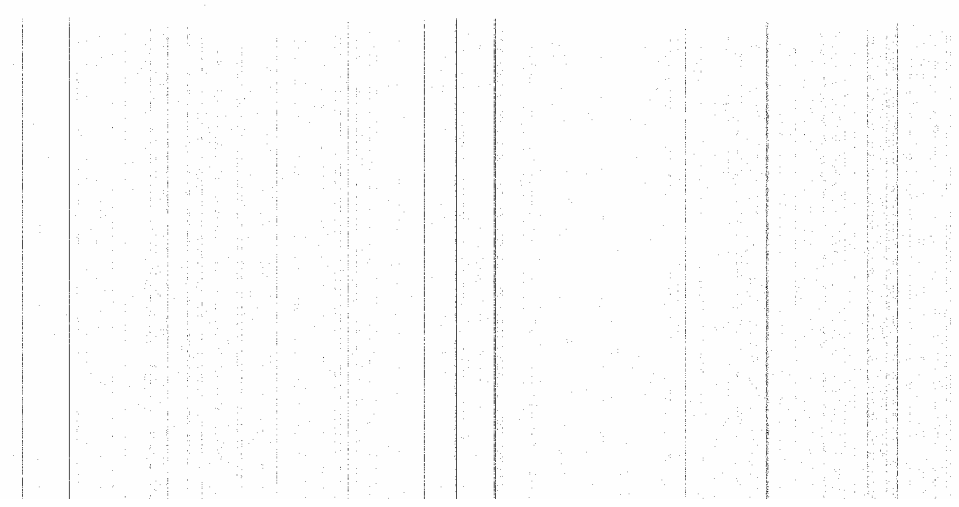


WSRC-TR-2004-00286, Revision 0

\section{APPENDIX B. SUMMARY DESCRIPTION OF THE MANUFACTURE OF OAK RIDGE BEADS}


WSRC-TR-2004-00286, Revision 0

\title{
LETTER REPORT
}

\section{PREPARTION OF COMPOSITE MONOSODIUM TITANATE IN A HYDROUS TITANIUM OXIDE SPHEROIDAL SORBENTS FOR SRNL}

\author{
Jack Collins and Rodney Hunt
}

Two batches of hydrous titanium oxide (HTiO) microspheres, which were embedded with fine monosodium titanate (MST) powder, were prepared by the internal gelation process for the Savannah River Technology Center (SRTC). The monosodium titanate $\mathrm{NaHTi}_{2} \mathrm{O}_{5}$ used in the preparations was supplied to Oak Ridge National Laboratory (ORNL) by SRTC personnel as a slurry. In the SRTC program entitled Engineered Monosodium Titanate (MST) for Accelerated Nuclear Waste Cleanup, the ORNL samples and other engineered composite materials will be evaluated with batch contact tests using a Savannah River Site (SRS) tank supernatant simulant with $5.6 \mathrm{M} \mathrm{Na}^{+}$. The SRS simulant will be spiked with ${ }^{139} \mathrm{Pu},{ }^{137} \mathrm{~Np}, \mathrm{U}$, and ${ }^{85} \mathrm{Sr}$. Each engineered sorbent was prepared from a common source of MST that was provided by SRTC. One of the ORNL samples had $\sim 50 \mathrm{wt} \%$ MST while the other sample had $\sim 32 \mathrm{wt} \% \mathrm{MST}$.

\section{INTRODUCTION}

A disadvantage of many inorganic ion exchangers, which are commercially available, is their physical form. Most inorganic ion exchangers are made as powders, unstable granular material, or pellets, which lacked reproducibility as sorbents. During the 1990s, a research and development (R\&D) program entitled Development and Testing of Spheroidal Inorganic Sorbents was sponsored by the Efficient Separtions and Processing Crosscutting Program (ESP) at ORNL. The goal of the ORNL program was to develop inorganic ion exchangers as structurally strong microspheres, which would improve the flow dynamics for column operations and expand the practical applications of these inorganic sorbents. One task of the ORNL program was to develop three type sodium titanate spheroidal sorbents. The first sorbent was pure sodium titanate microspheres, the second was hydrous titanium microspheres with fine sodium titanate powder embedded, and the third was titanium monohydrogen phosphate microspheres with sodium titanate powder embedded. These preparations used a slurry of fine sodium titanate powder from Boulder Scientific Company (Mead, CO). The preparations were designed so the sodium titanate powder would range from 9 to $25 \mathrm{wt} \%$ in the composite microspheres. The R\&D from this ESP program was used to prepare the new engineered composite materials of MST for the SRTC.

The internal gelation process provided a unique means for the preparation of composite microspheres in which the MST powder can be homogenously dispersed throughout the gelsphere matrix. Variations in several process parameters can control the type and shape of the hydrous metal oxide gel-spheres. This process provides a unique means to make inorganic ion exchangers more usable as an engineered form, which can be used in large-scale column separations. Sorbents in the form of spherules greatly enhance the flow dynamics in column operations. The spherules are stable forms and have little or no tendency to degrade under dynamic conditions. The crush strengths of the microspheres are in general considerably much better than those for granular forms of the same materials. A description of the internal gelation process and the optimum process control parameters for making hydrous titanium oxide 
microspheres are given the patent Method for Preparing Hydrous Titanium Oxide Gels and Spherules. ${ }^{1} \quad$ The development of the earlier developed ESP/ORNL sorbents and discussions about their effectiveness were reported elsewhere. ${ }^{2-5}$

\section{INTERNAL GELATION PROCESS}

The internal gelation process was originally developed at the KEMA laboratory in the Netherlands. ${ }^{6}$ In the late 1970 s, ORNL researchers began to utilize and improve the internal gelation process to prepare $\mathrm{UO}_{2},(\mathrm{U}, \mathrm{Pu}) \mathrm{O}_{2}, \mathrm{ThO}_{2}$, and $\left(\mathrm{UO}_{2}+\mathrm{UC}_{2}\right)$ micro spherical fuels. ${ }^{7-11}$ In the 1990s, ORNL researchers extended the boundaries of the internal gelation technology to prepare hydrous metal oxides spheres of $\mathrm{Ti}, \mathrm{Zr}, \mathrm{Fe}$, and of other cations for uses such as sorbent, waste forms, catalyst, getters, and dielectrics. ${ }^{12-19}$

The advantages of the internal gelation process for hydrous metal oxide microspheres include the following: (1) control of gelation time and microsphere size, (2) reproducible preparations, (3) homogeneous incorporation of fine particles of other materials into the microspheres, and (4) a highly developed large-scale engineering process. To maximize these advantages, the preparation of hydrous metal oxide microspheres requires a detailed understanding of the process chemistry gel-forming operation.

The four key reactions in the internal gelation process are given below. ${ }^{12}$ In the process, a clear broth is formed when a chilled solution of 3.2 $M$ hexamethylenetetramine (HMTA) and 3.2 $M$ urea is mixed with a chilled concentrated solution of titanium oxychloride $\left(\mathrm{TiOCl}_{2}\right)$ in dilute hydrochloric acid $(\mathrm{HCl})$.

1) complexation/decomplexation $2 \mathrm{CO}\left(\mathrm{NH}_{2}\right)_{2}+\mathrm{Ti}^{4+} \rightarrow \mathrm{Ti}\left[\mathrm{CO}\left(\mathrm{NH}_{2}\right)_{2}\right]_{2}{ }^{4+}$,

\section{2) hydrolysis}

$\mathrm{Ti}^{4+}+\mathrm{xH} 2 \mathrm{O} \rightarrow \mathrm{Ti}(\mathrm{OH})_{4} \cdot \mathrm{yH}_{2} \mathrm{O} \downarrow+4 \mathrm{H}^{+}$, $\mathrm{TiO}^{2+}+\mathrm{xH} 2 \mathrm{O} \rightarrow \mathrm{TiO}(\mathrm{OH})_{4} \cdot \mathrm{yH}_{2} \mathrm{O} \downarrow+2 \mathrm{H}^{+}$,

3) HMTA protonation

$$
\left(\mathrm{CH}_{2}\right)_{6} \mathrm{~N}_{4}+\mathrm{H}^{+} \rightarrow\left(\mathrm{CH}_{2}\right)_{6} \mathrm{~N}_{4} \cdot \mathrm{H}^{+}
$$

\section{4) HMTA decomposition}

$\left(\mathrm{CH}_{2}\right)_{6} \mathrm{~N}_{4} \cdot \mathrm{H}^{+}+3 \mathrm{H}^{+}+6 \mathrm{H} 2 \mathrm{O} \rightarrow 4 \mathrm{NH}_{4}{ }^{+}+6 \mathrm{CH}_{2} \mathrm{O}$

The major constituents of a broth for the preparation of the hydrous metal oxide microspheres are HMTA, urea, and the metal salt. Urea serves as a complexing agent for the metal (reaction 1). At certain concentrations, urea permits preparation of stable broths at 0 to $5^{\circ} \mathrm{C}$. These broths can remain clear and free of gelation or precipitation for reasonable periods of time. As the temperature of the broth droplets quickly rises upon contact with the hot silicone oil, decomplexation occurs (reaction 1). Hydrolysis of the titanium (reaction 2) is then permitted to occur. HMTA, a weak organic base, drives the hydrolysis reaction to completion. At first, the HMTA molecules are singularly protonated (reaction 3). Once most of the HMTA molecules 
( $\geq 95 \%$ ) are protonated, ${ }^{12}$ they begin to decompose (reaction 4) into ammonia molecules, which make the system even more basic. Each protonated HMTA molecule can effectively remove three additional hydrogen ions. The reaction products are ammonium chloride and formaldehyde. Urea also functions as a catalytic agent that accelerates the decomposition of protonated HMTA molecules. ${ }^{12}$

\section{LABORATORY-SCALE APPARATUS AND ITS OPERATION}

The new laboratory-scale apparatus (Fig. 1), which was used to make the HTiO/MST gel spherules, was a modification of an apparatus used to produce uranium and plutonium microspheres in a glove box in the late 1970s. The apparatus consisted of a reservoir to heat the silicone oil (Dow Corning 200 Fluid), a pump to circulate the silicone oil through the gelforming apparatus, a chilled broth pot, a vibrating nozzle system to control the size of the broth droplets, a glass gel-forming column, a downstream polyvinylchloride (PVC) transport line to provide a residence time for the gel spherules to hydrolyze and solidify, and a stainless-steel mesh product collector to collect and age the gel spheres and also to separate the silicone oil from the gel spheres.

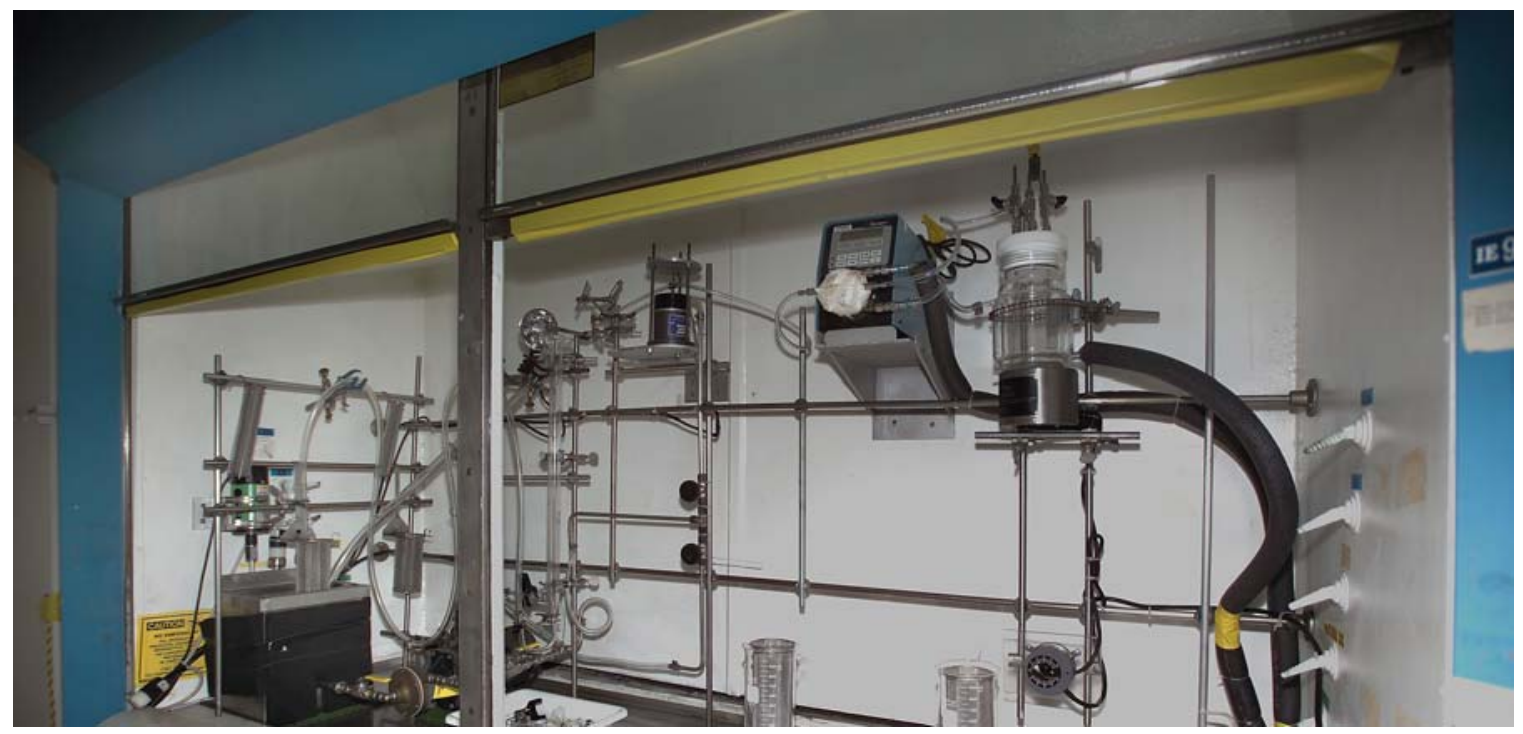

Fig. 1. Apparatus for the preparation of the HTiO/MST microspheres.

The silicone oil reservoir was a stainless steel open-top rectangular container, which is 7 in. wide by $8.3 \mathrm{in}$. long and $11.5 \mathrm{in}$. deep. Two 250 watt stainless steel heating blades were positioned at the rear of the reservoir to heat the oil. A thermocouple that was positioned in the basket at the bottom and near the front of the reservoir was connected to a temperature controller, which was used to control temperature of the oil. A Lightnin mixer with its stainless steel shaft positioned between the two heating blades and its stainless steel impeller located near the bottom of the reservoir was used to mix and maintain the oil at the desired temperature. A large removable stainless steel wire-mesh (100 mesh) basket was placed in the front space space in the reservoir to prevent any spilled gelled spherules from being pumped out of the reservoir into the circulating pump. An Eastern D-centrifugal pump was used to pump the hot oil from the reservoir through a $1 / 4$-ID stainless steel line to the vertically positioned glass gelation column. 
The flow from the pump was divided into two streams, which were controlled by manual valves. The flow of one stream was routed through a vertically positioned PVC tube whose open end is positioned about 3 in. down into the gelation column. Oil from this tube provided most of the flow through the gel-forming tube and downstream serpentine PVC tube to the collection basket. The typical flow rate was between 250 and $300 \mathrm{~mL} / \mathrm{min}$. A small hole was punctured through the PVC tube about 2 in. above the top of the gelation column to accommodate a blunt-end droplet forming needle.

The other hot silicone oil stream from the pump was routed to glass fitting at the bottom of the gelation column and flowed up through a tubular jacket that surrounded the central gelation column. The hot oil over-flows near the top edge of the gel-forming column spilled into an overflow cup. Only a small fraction of it flowed into the gel-forming column. The overflow oil flowed back to reservoir through a PVC tube.

The broth-droplet forming system components consisted of chilled Pyrex broth vessel (Fig.1), a Magnetic Stirrer positioned under the broth vessel to mix the broth to keep the MST particles suspended, a peristaltic pump, a vibrator and controller from Alpha-M Corp, a bluntend electropolished stainless steel 20 gage needle from Popper \& Sons. The peristaltic pump was used to pump the chilled broth-MST mixture from the broth vessel through a 3/32-in. ID Tygon tube to the droplet-forming needle at a rate of $\sim 15 \mathrm{~mL} / \mathrm{min}$. During the formation of the MST composition microspheres, the tip of the needle was horizontally positioned in the center of the PVC tube $\sim 2$ in. above the top of the gelation column. The tube passes through the vibrator $\sim 1 \mathrm{ft}$. from the needle. The frequency of the vibrator was set to provide a frequency of $120 \mathrm{hz}$ at an amplitude of 1.5. This frequency was needed to produce droplets in the desired diameter size range.

\section{PREPARATION OF HTIO/MST COMPOSITE SORBETS FOR SRTC}

Two $0.5 \mathrm{~L}$ bottles of slurry of fine MST powder were received from Charles Nash of SRTC for use in the preparation of hydrous titanium oxide microspheres, which were homogenously embedded with the MST powder. The SRS batch number for the MST was 00QAB417.

The MST was sieved with a stainless steel 150 mesh sieve using deionized water to remove large particles from the slurry. The main concern was the potential to plug the 20 gage needle. Only a very small portion of the powder failed to pass through the sieve. A small amount of solids, which were not MST, was also removed by the sieve. The slurry filtrate was collected in a $4 \mathrm{~L}$ plastic beaker and allowed to settle for about 7 days. Afterward the water above the settled powder was removed by decantation. Subsequently, a $30.282 \mathrm{~g}$ sample of this slurry was pulled while mixing and then air-dried at ambient temperature to a constant weight in a small plastic beaker.

30.282 g slurry $\rightarrow 8.002 \mathrm{~g}$ (air-dried MST) or 26.42 wt. \% MST powder

Stock solutions of (1.71 $\mathrm{M} \mathrm{TiOCl}_{2}$ and $\left.1.4 \mathrm{M} \mathrm{HCl}\right)$ and (3.2 $\mathrm{M}$ urea and 3.2 $\mathrm{M}$ HMTA) were prepared for use in the preparations. To check the gel time of the broth and the functionality of the operating system, hydrous titanium oxide microspheres were first prepared.

Page 52 of 56 
A $260.1 \mathrm{~g}(220.3 \mathrm{~mL})$ broth was prepared $\left(\right.$ at $\sim 5^{\circ} \mathrm{C}$ ) with the following composition: $0.78 \mathrm{M} \mathrm{Ti}$ ${ }^{+4}, 0.64 \mathrm{M} \mathrm{H}^{+}, 1.75 \mathrm{M}$ HMTA, and1.75 $M$ urea. The gel-forming temperature of the silicone oil was $\sim 90^{\circ} \mathrm{C}$, and the gelation time of the droplets was $\sim 9 \mathrm{~s}$. The gel-spheres were collected in a stainless steel mesh basket and aged for $30 \mathrm{~m}$. Afterward, the spheres were washed with solutions of trichloroethylene (TCE) to remove any remaining silicone oil from the surface of the spheres. This followed by thoroughly washing the spheres with $0.5 \mathrm{M}$ ammonia hydroxide $\left(\mathrm{NH}_{4} \mathrm{OH}\right)$ to remove the HMTA, urea, and ammonia nitrate from the sphere. The batch washing sequence was repeated 6 times until conductive measurements of the wash solutions were constant. The conductivity of the first wash solution was $\sim 45,000 \mu$ mhos. The value of the last wash was $850 \mu$ mhos $\mu$ mho the same as the conductivity of the $0.5 \mathrm{M} \mathrm{NH}_{4} \mathrm{OH}$ solution, which was used to wash the microspheres.

The spheres were placed in a stainless steel pan and air dried at ambient temperature for several days until a constant weight ( $48.5 \mathrm{~g}$ ) was obtained. Twice the quantity of Ti broth used in this preparation was used in each of the HTiO/MST microsphere preparations.

In the HTiO/MST ( $\sim 50$ wt. $\%)$ preparation, $246 \mathrm{~g}$ of slurry $(246 \times 0.2642=65 \mathrm{~g}$ airdried MST) was added to $520.2 \mathrm{~g}$ of chilled Ti broth with mixing to keep the MST powder in suspension. The goal was to make composite air-dried HTiO/MST microspheres, which were $\sim 50$ wt.\% MST. The chilled broth mixture was pumped with the peristaltic pump from the broth vessel at a rate of $15 \mathrm{~mL} / \mathrm{min}$ through a 3/32-ID Tygon tube through the vibrator to the 20 gage blunt-end needle which formed broth droplets that formed gel-spheres within $9 \mathrm{~s}$ upon entering the flowing stream of $90{ }^{\circ} \mathrm{C}$ heated silicon oil. The short transport time of the broth to the heated oil made it possible for the MST to remain in suspension. The composite gel spheres were collected in two 80 mesh stainless steel baskets, and afterwards they were aged for $20 \mathrm{~min}$. After draining the oil, each basket full of gel spheres was washed four times with TCE and then six times with $0.5 \mathrm{M} \mathrm{NH}_{4} \mathrm{OH}$. The microspheres were then spread out in two stainless steel pan and allowed to air dry. The drying process was accelerated by placing a heat light $\sim 2 \mathrm{ft}$ above the pan. Since the equivalent of $65 \mathrm{~g}$ of air-dried MST was added to the broth initially, little loss of product occurred.

One problem during this preparation was the tendency of the HTiO/MST microspheres to tightly bond together upon drying. A large fraction of the microspheres could not be separated easily when they were sieved. The clumps had to be physically broken apart, which led to many cracked spheres (see Fig. 2). This preparation yielded $\sim 78 \mathrm{~g}$ of microspheres in the 300 to $1000 \mu \mathrm{m}$ diameter range.

In the third preparation, all if the broth was delivered to the forming column as droplets. About $246 \mathrm{~g}$ of slurry $(151.5 \mathrm{~g} \times 0.2642=40 \mathrm{~g}$ air-dried MST $)$ was added to $520.2 \mathrm{~g}$ of chilled Ti broth, which was mixed to keep the MST powder in suspension. As in the other preparations, the broth mixture was pumped a peristaltic pump from the broth vessel at a rate of $15 \mathrm{~mL} / \mathrm{min}$ to the droplet forming needle. The same aging, washing, and drying steps were repeated. To minimize clumping in the drying step, three stainless pans were used to provide fewer layers of microspheres and the heat lamp was not used. A total of $125.4 \mathrm{~g}$ of air-dried beads was obtained. Since the loss of MST powder was minimal during the washing steps, the wt. percentage of airdried MST in the air-dried composite microspheres was 32. After the microspheres were dried, 
they were sieved. Approximately $104 \mathrm{~g}$ were in the 300 to $1000 \mu \mathrm{m}$ diameter range and $75 \mathrm{~g}$ were in the 300 to $710 \mu \mathrm{m}$ range. Fig. 3 shows a scaled picture of these microspheres.

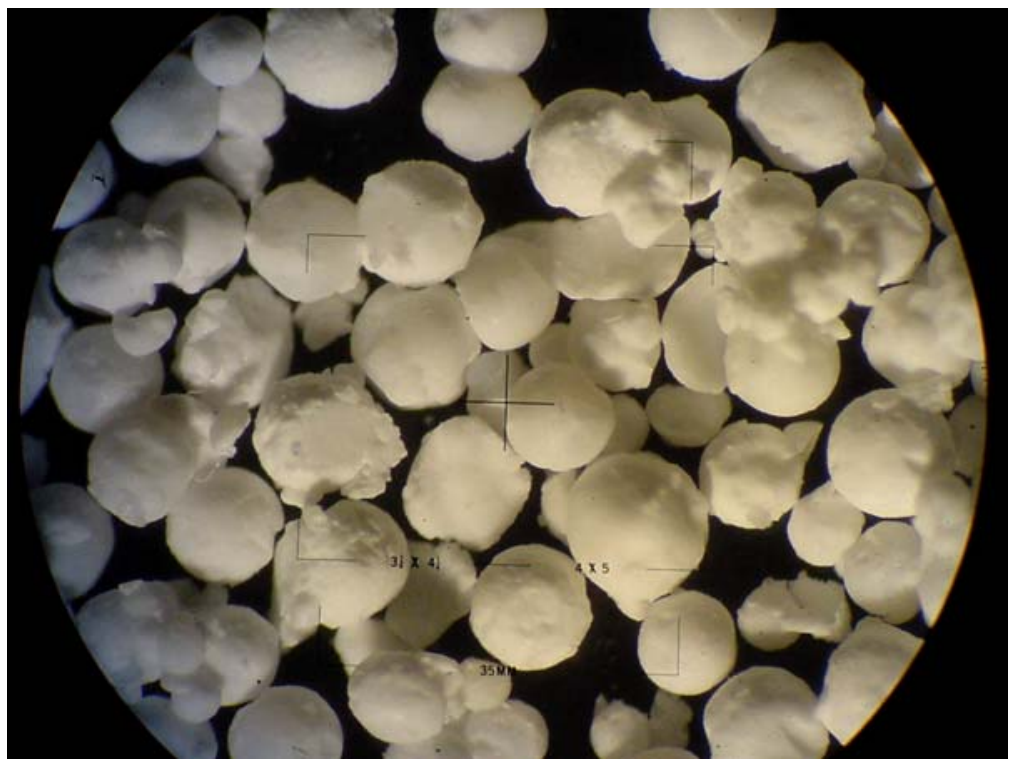

Fig.2. ORNL 50 wt \% MST Hydrous Titanium Spheres (Picture provided by SRTC)

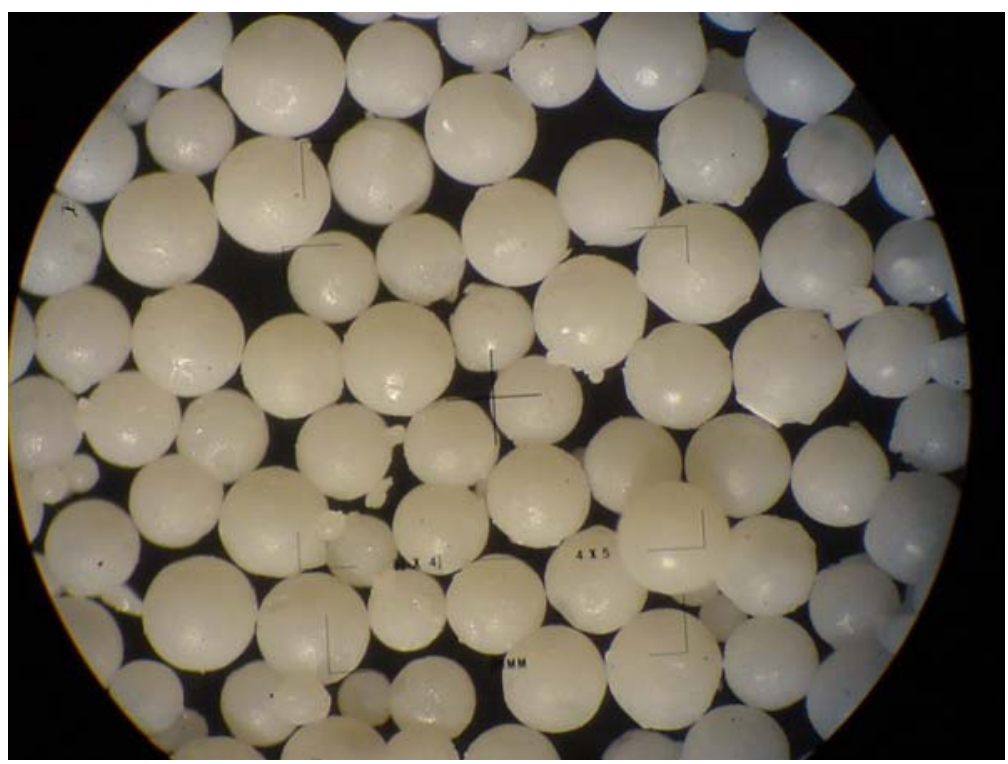

Fig. 3. ORNL $32 \mathrm{wt} \%$ MST Hydrous Titanium Spheres (Picture provided by SRTC) 
WSRC-TR-2004-00286, Revision 0

\section{References}

1. J. L. Collins, U.S. Patent No. 5,821,186, Method of Preparing Hydrous Titanium Oxide Gels and Spherules (issued 10/13/1998).

2. J. L. Collins, B. Z. Egan, K. K. Anderson, C. W. Chase, and J. T. Bell, Batch Test Equilibration Studies Examining the Removal of Cs, Sr, and Tc from Supernatants from ORNL Underground Storage Tanks by Selected Ion Exchangers, published in the proceedings of the 2nd International Conference of Waste Management: "Challenges and Innovations in the Management of Hazardous Waste," which was held May 10 - 12, 1995, Washington, DC.

3. J. L. Collins, B. Z. Egan, and K. K. Anderson, Development and Testing of Spheroidal Inorganic Sorbents, published in the proceedings of the Efficient Separations and Processing Crosscutting Program 1997 Technical Exchange Meeting, January 28-30, 1997 Gaithersburg, Maryland.

4. D. J. Davidson, J. L. Collins, K. K. Anderson, C. W. Chase, and B. Z. Egan, Removal of Cesium, Technetium, and Strontium from Tank Waste Supernatant, ORNL/TM-13612, August 1998.

5. J. L. Collins and J. S. Watson, Economic Evaluation for the Production of Sorbents and Catalysts Derived from Hydrous Titanium Oxide Microspheres Prepared by the HMTA Internal Gelation Process, ORNL/TM -1999/212, April 2000.

6. F. W. v.d. Bruggens, A. J. Noothout, M. E. A. Hermans, J. B. W. Knaji, and O. Votocek, "A U(VI)-Process for Microsphere Production," Proc. Symp. Sol-Gel Processes and Reactor Fuel Cycles, Gatlingburg, Tennessee, May 4-7, 1970, CONF-700502, U. S. Atomic Energy Commission (1970).

7. P. A. Haas, J. M. Begovich, A. D. Ryon, and J. S. Vavruska, "Chemical Flowsheet Conditions fro Preparing Urania Spheres by Internal Gelation," Ind. Eng. Chem. Prod. Res. Dev., Vol. 19, No. 3, (1980).

8. M. H. Lloyd, J. L. Collins, R. L. Fellows, S. E. Shell, D. H. Newman, and W. B. Stines, A Gel Sphere Process for FBR Fuel Fabrication from Coprocessed Feed, ORNL/TM-8399, February 1983.

9. M. H. Lloyd, J. L. Collins, and S. E. Shell, U.S. Patent No. 4,502,987, entitled Method of Controlling Crystallite Size in Nuclear-Reactor Fuels (issued 3/5/1985).

10. P. A. Haas, V. L. Fowler, and M. H. Lloyd, U.S. Patent No. 4,663,093, Preparation of Nuclear Spheres by Floatation-Internal Gelation, (5/5/1987).

11. P. A. Haas, "Formation of Uniform Liquid Drops by Application of Vibration to Laminar Jets," Ind. Eng. Chem. Res. Vol. 31, No. 3, (1992).

12. J. L. Collins, M. F. Lloyd, and R. L. Fellows, "The Basic Chemistry Involved in the Internal-Gelation Method of Precipitating Uranium as Determined by pH Measurements," Radiochimica Acta 42, 121-34, (1987).

13. Jack L. Collins, Robert J. Lauf, and Kimberly K. Anderson, U.S. Patent No. 2003/0021747 A1, entitled Method of Preparing Hydrous Iron Oxide Gels and Spherules (1/30/2003).

14. J. L. Collins, R. J. Lauf, and K. K. Anderson, U.S. Patent No. 6,599,493 B2, Method of Preparing Hydrous Iron Oxide Gels and Spherules (7/29/2003).

15. J. L. Collins, U.S. Patent No. 6,602,919 B1, Method of Preparing Hydrous Zirconium Oxide Gels and Spherules (8/5/2003). 
16. A. H. Bond, M. J. Gula, J. T. Harvey, J. M. Duffey, E. P. Horwitz, R. D. Rogers, and J. L. Collins, "Flowsheet Feasibility Studies Using ABEC Resins for Removal of Pertechnetate from Nuclear Wastes," Ind. Eng. Chem. Res. 38, 1683-1689, (1999).

17. J. L. Collins, B. Z. Egan, K. K. Anderson, C. W. Chase, J. E. Mrocheck, J. T. Bell, G. E. Jernigan, Evaluation of Selected Ion Exchangers for the Removal of Cesium from MVST W-25 Supernate, ORNL/TM-12938, April 1995.

18. D. J. Davidson, J. L. Collins, K. K. Anderson, C. W. Chase, and B. Z. Egan, Removal of Cesium, Technetium, and Strontium from Tank Waste Supernatant, ORNL/TM-13612, August 1998.

19. J. L. Collins and K. K. Anderson, Development of Spheroidal Inorganic Sorbents for Treatment of Acidic Salt-bearing Liquid Waste, ORNL/TM-2000/367, September 2001. 